\title{
Effects of Complement Opsonization of HIV on Dendritic Cells and Implications for the Immune Response
}

\author{
Rada Ellegård
}

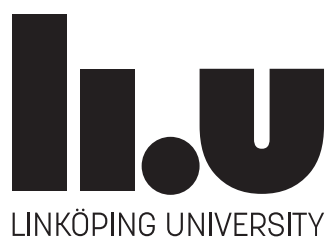

Department of Clinical and Experimental Medicine (IKE) Division of Hematopoiesis and Developmental Biology (HUB) Faculty of Medicine and Health Sciences Linköpings universitet, SE-581 83 Linköping, Sweden Linköping 2018 
(C) Rada Ellegård, 2018

Printed in Sweden by LiU Tryck 2018

Cover art by Maja and Elsa Ellegård

ISSN $0345-0082$

ISBN 978-91-7685-221-7 
Effects of Complement Opsonization of HIV on Dendritic Cells and Implications for the Immune Response

By

Rada Ellegård

October 2018

ISBN 978-91-7685-221-7

Linköping University medical dissertations No. 1640

ISSN 0345-0082

Department of Clinical and Experimental Medicine (IKE)

Linköpings Universitet

SE-581 83 Linköping, Sweden 



\section{Abstract}

Dendritic cells are key players during HIV pathogenesis, and shape both the immediate immune response at the site of infection as well as directing the adaptive immune response against the virus. HIV has developed a plethora of immune evasion mechanisms that hijack dendritic cell functions, suppressing their ability to mount an accurate immune response and exploiting them for efficient viral transfer to target $\mathrm{T}$ cells.

To achieve successful replication within dendritic cells without triggering danger signaling, HIV accomplishes a delicate balance where only a low level of transcription can be sustained without triggering antiviral responses that would harm the virus. Here, we describe how the presence of HSV2 coinfection, which is very common in geographic areas with a high HIV prevalence and almost triples the risk of HIV acquisition, alters dendritic cell state to support much higher levels of HIV infection. We found this effect to be mediated by the STING pathway, which is involved in the sensing of DNA in the cell cytosol. STING activation led to an upregulation of factors such as IRF3 and NFkB that can be used for HIV transcription and a degradation of factors that restrict HIV replication.

In addition, we describe how HIV exploits the human complement system, a group of proteins that usually help the human body to identify dangerous pathogens while avoiding reaction towards self. HIV can coat itself, i.e. become opsonized, in complement fragments that are typically only present on the body's own cells, allowing it to activate signaling pathways that are associated with tolerance. Dendritic cells that come into contact with complement opsonized HIV do not mount danger responses, despite the fact that HIV-derived single stranded RNA triggers the pathogen recognition receptor TLR8. The suppression of danger responses is mediated by activation of complement receptor 3 , and leads to an increased infection of the dendritic cell and affects its interactions with other immune cells. There is a lack of recruitment of NK cells to the site of infection, and an inhibition of NK cell killing, which plays an important role in the destruction of HIV-infected cells in vivo. T cells primed by dendritic cells exposed to complement opsonized HIV have a lower ability to develop towards effector phenotype, and have an increased expression of the markers PD1, TIM3 and LAG3 which are associated with $\mathrm{T}$ cell dysfunction and exhaustion. In addition, $\mathrm{T}$ cells primed by these dendritic cells in the presence of NK cells upregulate markers $\mathrm{CD}_{3} 8, \mathrm{CXCR}_{3}$ and CCR4, which have been linked to an increased susceptibility to HIV infection.

In summary, we add to the current knowledge on HIV immune evasion mechanisms that allow the virus to establish infection, as well as describing mechanisms that govern whether dendritic cells mount danger signaling and an immune response or not.

Key words: HIV, dendritic cells, complement, innate immune response, TLR signaling, T cell activation, $\mathrm{NK}$ cells, inflammation, antiviral response, immune evasion 


\section{Populärvetenskaplig sammanfattning}

HIV är ett virus som huvudsakligen sprids via sexuell kontakt och som infekterar och förstör immunceller (vita blodkroppar). Utan behandling förstörs immunförsvaret och en enkel förkylning kan leda till döden.

Dendritiska celler brukar vara de första immuncellerna som kommer i kontakt med HIV vid sexuell smitta, och har en stor påverkan på hur starkt immunförsvar kroppen bildar mot viruset. HIV har en mängd olika verktyg för att styra dendritiska cellers svar efter att de kommit i kontakt med viruset, så att HIV undkommer att bli dödat av immunförsvaret och kan istället etablera och bibehålla en infektion. Vår forskning beskriver några av dessa verktyg, och hur HIV-infektion inom den dendritiska cellen regleras.

En viktig faktor som påverkar risken för smittoöverföring av HIV vid sexuell kontakt är om man redan bär på andra könssjukdomar, som t ex genitalherpes. Genitalherpes orsakas oftast av herpessimplexvirus typ 2 (HSV2), och är väldigt vanligt förekommande i samma geografiska områden där HIV har störst spridning. Individer som bär på HSV2 har upp till tre gånger större risk att få en HIVinfektion. Vi visar hur en befintlig HSV2 infektion ökar HIV-infektionen av dendritiska celler genom att höja nivåerna av faktorer som HIV behöver för produktion av nya viruspartiklar och minska nivåerna av faktorer som normalt begränsar infektion. Denna effekt sker via aktivering av ett varningssystem inne i cellen som reagerar på DNA som befinner sig på en plats där cellens eget DNA inte brukar vara. Närvaron av DNA på fel plats brukar vara ett tecken på att cellen drabbats av en virusinfektion och varningssystemet ändrar miljön inne i cellen så att viruset inte kan föröka sig. I detta fall sker alltså det motsatta - HIV-infektionen ökar när varningssystemet aktiverats av HSV2.

Vidare beskriver vi hur HIV utnyttjar komplementsystemet, en samling proteiner som hjälper kroppen att skilja mellan farliga inkräktare och dom egna cellerna. HIV klär sig i komplementproteiner på ett sätt som liknar kroppens egna celler. Dendritiska celler som kommer i kontakt med komplementklätt HIV svarar inte med att signalera fara, trots att viruset känns igen av en av dendritiska cellens receptorer för virus-komponenter. Svaret som genereras av dendritiska cellen leder till en minskad rekrytering av NK celler, en immuncell som är viktigt för att ta död på virusinfekterade celler, samt en försämrad förmåga hos NK cellerna att ta död på andra celler. Detta gynnar högst troligen HIV:s chanser att etablera en infektion.

Dendritiska cellernas interaktion med T celler påverkas också när HIV är komplementklätt. T celler är immunceller som är viktiga för bekämpningen av infektioner, och är HIV:s huvudsakliga målceller, där viruset kan föröka sig effektivast. Dendritiska celler som har kommit i kontakt med komplementklätt HIV har en försämrad förmåga att stimulera T celler att forma ett effektivt immunsvar. Dessutom visar T celler som fătt samspela med de dendritiska cellerna, i närvaro av NK celler, tecken på sämre funktion samt ökad känslighet för HIV-infektion.

Våra studier bidrar kring kunskapen kring hur HIV undkommer immunförsvaret och hur HIV-infektion regleras i dendritiska celler, samt kring vad som avgör om dendritiska celler svarar med att signalera fara och initiera ett immunsvar eller inte. 


\section{Table of Contents}

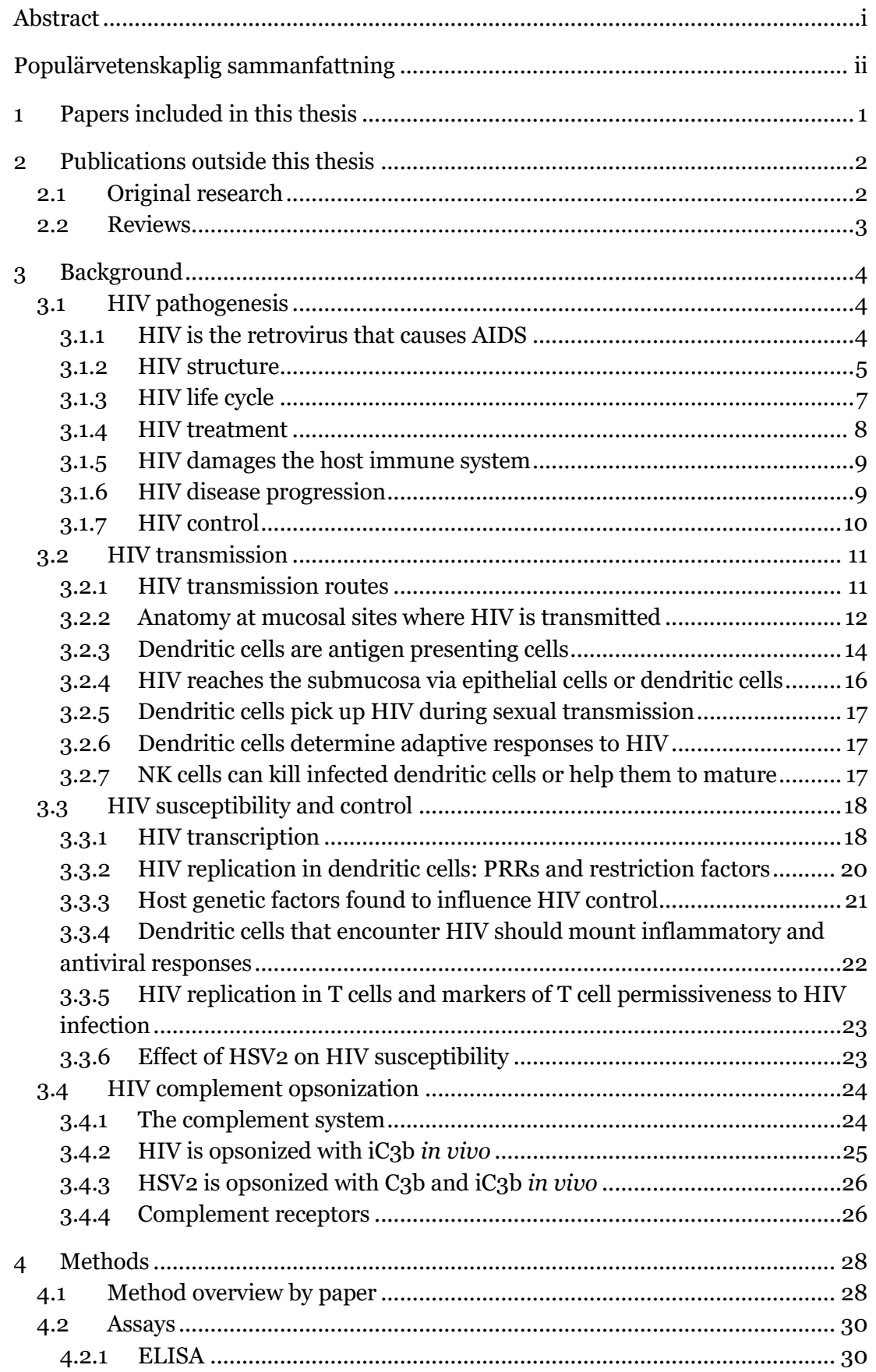


4.2.2 Western blot ................................................................................. 30

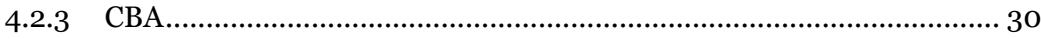

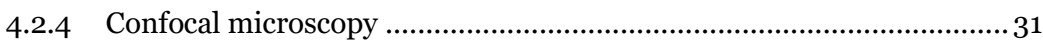

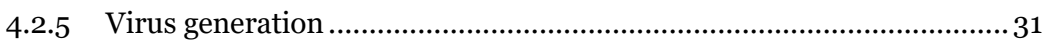

4.2.6 Complement opsonization...................................................................32

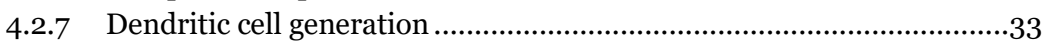

4.2.8 NK cell purification and NK mediated killing .......................................34

4.2.9 T cell stimulation assays and readouts ...................................................35

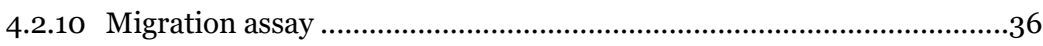

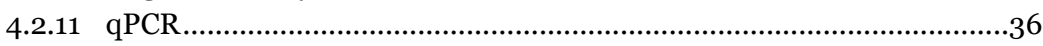

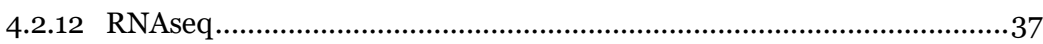

4.2.13 Flow cytometry ............................................................................. 38

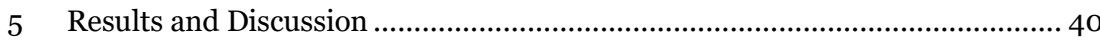

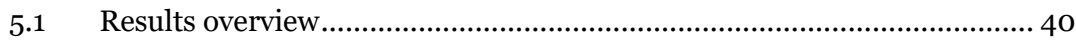

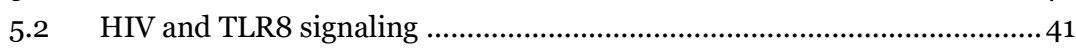

5.2.1 HIV triggers weak danger responses in dendritic cells .........................41

5.2.2 HIV triggers TLR8 ........................................................................... 41

5.2.3 What happens downstream of TLR8 ….............................................. 41

5.2.4 Kinetics of danger responses to HIV ................................................42

5.3 HIV and complement signaling..............................................................4

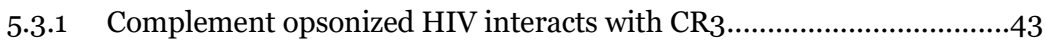

$5.3 .2 \quad$ TLR-CR crosstalk ..............................................................................4

$5.4 \quad$ HIV and the STING pathway .................................................................45

5.4.1 IFI16 and cGAS signaling converge in the activation of STING ............45

5.4.2 STING can be involved in a later wave of danger signaling in HIVexposed dendritic cells....................................................................................45

5.4.3 HSV2 signaling through cGAS/STING increases HIV replication ....... 46

$5.5 \quad$ HIV-exposed dendritic cells and NK cells .................................................4

5.5.1 Complement opsonization of HIV suppresses dendritic cell recruitment

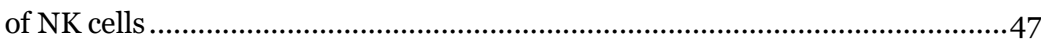

5.5.2 Dendritic cells exposed to complement opsonized HIV suppress NK killing 48

5.6 HIV-exposed dendritic cells and T cells .................................................. 48

5.6.1 HIV-exposed dendritic cells suppress T cell proliferation ................... 49

5.6.2 T cells primed by HIV-exposed dendritic cells differentiate into central memory phenotype ....................................................................................... 49

5.6.3 Dendritic cells exposed to complement opsonized HIV induce T cells with an exhausted phenotype ......................................................................... 50

5.6.4 Dendritic cells exposed to complement opsonized HIV induce

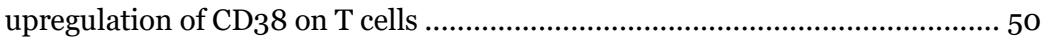

5.6.5 Dendritic cells exposed to complement opsonized HIV induce upregulation of CXCR3 and CCR4 on T cells in the presence of NK cells ......... 51

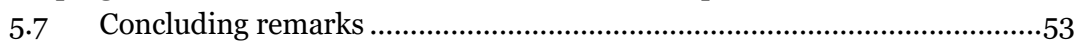

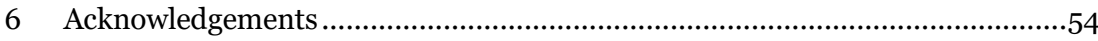

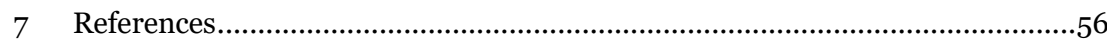




\section{Papers included in this thesis}

\section{Paper I:}

HSV2 cellular programming enables productive HIV infection in dendritic cells. Crisci E, Ellegård $\boldsymbol{R}^{*}$, Svanberg $C^{*}$, Khalid M, Hellblom J, Okuyama K, Bhattacharyaa P, Lifson J, Nyström S, Shankar EM, Eriksson K, Larsson M. Manuscript

\section{Paper II:}

Complement opsonization of HIV-1 results in decreased antiviral and inflammatory responses in immature dendritic cells via $\mathrm{CR}_{3}$.

Ellegård R, Crisci E, Burgener A, Sjöwall C, Birse K, Westmacott G, Hinkula J, Lifson JD, Larsson M. J Immunol. 2014 Nov 1;193(9):4590-601

\section{Paper III:}

Impaired NK Cell Activation and Chemotaxis toward Dendritic Cells Exposed to Complement-Opsonized HIV-1.

Ellegård R, Crisci E, Andersson J, Shankar EM, Nyström S, Hinkula J, Larsson M. J Immunol. 2015 Aug 15;195(4):1698-704

\section{Paper IV:}

Complement-Opsonized HIV-1 Alters Cross Talk Between Dendritic Cells and Natural Killer (NK) Cells to Inhibit NK Killing and to Upregulate PD-1, CXCR3, and CCR4 on T Cells.

Ellegård R, Khalid $M$, Svanberg $C$, Holgersson H, Thorén $Y$, Wittgren $M K$, Hinkula J, Nyström S, Shankar EM, Larsson M. Front Immunol. 2018 Apr 30;9:899

* = equal contribution 


\section{Publications outside this thesis}

\subsection{Original research}

Human IgM monoclonal antibodies block HIV-transmission to immune cells in cervicovaginal tissues and across polarized epithelial cells in vitro.

Devito C, Ellegård R, Falkeborn T, Svensson L, Ohlin M, Larsson M, Broliden K, Hinkula J. Sci Rep. 2018

HIV Interferes with Mycobacterium tuberculosis Antigen Presentation in Human Dendritic Cells.

Singh SK, Andersson AM, Ellegård R, Lindestam Arlehamn CS, Sette A, Larsson $M$, Stendahl O, Blomgran R. Am J Pathol. 2016 Dec;186(12):3083-309

Aberrant Inflammasome Activation Characterizes Tuberculosis-Associated Immune Reconstitution Inflammatory Syndrome.

Tan HY, Yong YK, Shankar EM, Paukovics G, Ellegård R, Larsson M, Kamarulzaman A, French MA, Crowe SM. J Immunol. 2016 May 15;196(10):405263

Complement Opsonization Promotes Herpes Simplex Virus 2 Infection of Human Dendritic Cells.

Crisci E, Ellegård R, Nyström S, Rondahl E, Serrander L, Bergström T, Sjöwall C, Eriksson K, Larsson M. J Virol. 2016 Apr 29;90(10):4939-50

Chronic hepatitis $\mathrm{C}$ virus infection triggers spontaneous differential expression of biosignatures associated with $\mathrm{T}$ cell exhaustion and apoptosis signaling in peripheral blood mononucleocytes.

Barathan M, Gopal K, Mohamed R, Ellegård R, Saeidi A, Vadivelu J, Ansari AW, Rothan HA, Ravishankar Ram M, Zandi K, Chang LY, Vignesh $R$, Che KF, Kamarulzaman A, Velu V, Larsson M, Kamarul T, Shankar EM. Apoptosis. 2015 Apr;20(4):466-80

HIV-Mycobacterium tuberculosis co-infection: a 'danger-couple model' of disease pathogenesis.

Shankar EM, Vignesh R, Ellegård R, Barathan M, Chong YK, Bador MK, Rukumani DV, Sabet NS, Kamarulzaman A, Velu V, Larsson M. Pathog Dis. 2014 Mar;70(2):110-8

Blocking of integrins inhibits HIV-1 infection of human cervical mucosa immune cells with free and complement-opsonized virions.

Tjomsland $V^{*}$, Ellegård $\boldsymbol{R}^{*}$, Kjölhede P, Wodlin NB, Hinkula J, Lifson JD, Larsson M. Eur J Immunol. 2013 Sep;43(9):2361-72 
Complement opsonization of HIV-1 results in a different intracellular processing pattern and enhanced MHC class I presentation by dendritic cells.

Tjomsland $V^{*}$, Ellegård $\boldsymbol{R}^{*}$, Burgener $A, \operatorname{Mogk} K$, Che KF, Westmacott $G$, Hinkula J, Lifson JD, Larsson M. Eur J Immunol. 2013 Jun;43(6):1470-83

Complement opsonization of HIV-1 enhances the uptake by dendritic cells and involves the endocytic lectin and integrin receptor families.

Tjomsland $V^{*}$, Ellegård $\boldsymbol{R}^{*}$, Che K, Hinkula J, Lifson JD, Larsson M. PLoS One. 2011;6(8):e23542

* = equal contribution

\section{$2.2 \quad$ Reviews}

Functional role of mucosal-associated invariant T cells in HIV infection.

Saeidi A, Ellegård R, Yong YK, Tan HY, Velu V, Ussher JE, Larsson M, Shankar EM. J Leukoc Biol. 2016 Aug;100(2):305-14.

Molecular signatures of T-cell inhibition in HIV-1 infection.

Larsson $M$, Shankar EM, Che KF, Saeidi A, Ellegård R, Barathan $M$, Velu V, Kamarulzaman A. Retrovirology. 2013 Mar 20;10:31. doi: 10.1186/1742-4690-1031.

Targeting HIV-1 innate immune responses therapeutically.

Ellegård R, Shankar EM, Larsson M. Curr Opin HIV AIDS. 2011 Sep;6(5):435-43 


\section{Background}

\subsection{HIV pathogenesis}

\subsubsection{HIV is the retrovirus that causes AIDS}

Acquired immune deficiency syndrome (AIDS) was first described in scientific literature in the beginning of the 1980 s as a novel illness affecting homosexual men in California, and as a previously undescribed wasting disease affecting people in Uganda [1]. In 1983, human immunodeficiency virus (HIV) was identified as the virus that caused AIDS [1]. The virus spread rapidly, and by 1985 cases were reported from every WHO region [1]. HIV incidence peaked in 2000, with more than 3 million new infections that year, and then began to decline [2]. Incidence in 2010 was $35 \%$ lower compared to 2000, but there has not been any substantial decrease in incidence after 2010 [2].

The Joint United Nations Program on HIV/AIDS (UNAIDS) estimates that more than 70 million people have been infected with HIV, and that approximately 35 million have died due to the infection since the beginning of the epidemic [3]. Although the number of annual AIDS-related deaths have fallen by $48 \%$ since the peak in 2005 (2 million), the virus is currently the second most common cause of death in Africa (after lower respiratory tract infections) [4].

HIV is grouped to the genus Lentivirus within the family of Retroviridae, subfamily Orthoretrovirinae [5]. HIV can be further be classified into the types 1 and 2 (HIV-1, HIV-2) on the basis of genetic characteristics and differences in viral antigens [5]. HIV-1 causes more severe disease than HIV-2 and is much more infectious; of total HIV prevalence, HIV-2 accounts for only 0.3\% and HIV-1 accounts for the rest [5]. Throughout this thesis, "HIV" refers to HIV-1 unless otherwise specified.

Epidemiologic and phylogenetic analyses imply that HIV was introduced into the human population between 1920 and 1940, and that it evolved from non-human primate immunodeficiency viruses i.e. simian immunodeficiency viruses (SIV) [5]. SIV naturally occurs in over 45 species of non-human primates in Africa [6]. In these natural hosts, SIV does not lead to severe disease and is in some cases even totally asymptomatic [6]. In contrast, in non-natural host species, such as Asian macaques, the virus is not endemic and SIV infection leads to a similar disease to the one observed in humans infected with HIV [6]. There are no lentiviruses that naturally infect mice, and although the humanized mouse models that have been developed allow the study of some aspects of HIV infection, they fail to recapitulate basic features of HIV pathogenesis [7]. Infection of non-human primates, most commonly Asian rhesus macaques, with SIV thus remains the most accurate animal model for HIV [7].

In addition to animal models, HIV research utilizes human material, either from HIV infected patients or from healthy donors. In our group, we base our research on immune cells and tissue explants (biopsies) derived from healthy individuals that we collect, culture and then subject to HIV infection and/or various other factors in our lab. 


\subsubsection{HIV structure}

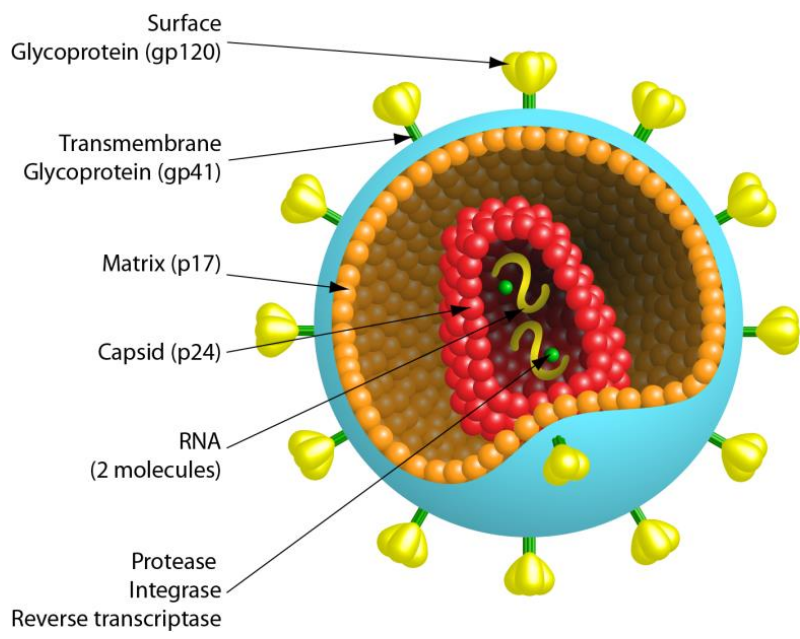

Figure 1. HIV structure. Modified from [5]. The HIV particle has an outer lipid bi-layer as its envelope, on the surface of which are knobs composed of trimers of gp12o surface protein anchored to the membrane by trimers of transmembrane protein gp41. Underneath the envelope is a symmetrical outer capsid membrane made up by the matrix protein (p17), and inside this outer capsid is an inner conical capsid composed of p24. The narrowest point of the conical capsid is anchored to the outer capsid membrane. Inside the conical capsid is the HIV genome: two identical single positive strands of RNA. Several molecules of the viral enzyme reverse transcriptase, RNase $H$ and integrase are bound to the nucleic acids of the genome.

The HIV virion is spherical, and approximately 10onm in diameter [5]. For a schematic of HIV structure, see Figure 1. The virus is covered in a lipid membrane envelope, acquired from the host cell during budding. Within this envelope are knobs, composed of trimers of gp120 surface protein anchored to the membrane by trimers of the transmembrane protein gp41 [5]. It is these knobs that HIV uses to bind to and fuse with the target cell membrane.

Underneath the envelope is an outer capsid membrane consisting of viral matrix proteins, p17. Within the symmetrical p17 capsid is an inner capsid, which consists of viral capsid protein p24 and has a conical shape [5]. Inside this inner capsid, is the HIV genome, which consists of two identical single-stranded RNA molecules, bound to several copies of the viral enzymes reverse transcriptase, RNase $\mathrm{H}$ and integrase [5].

The viral genome codes for the structural proteins needed to build new virions, as well as for enzymes - reverse transcriptase, RNase $\mathrm{H}$, integrase and viral protease - needed for replication. In addition, the genome codes for several small proteins known as regulatory elements, that perform various functions involved in viral replication, budding and pathogenesis. For a schematic illustration of the HIV genome, see Figure 2, and for an overview of genome components and their functions, see

Table 1. 


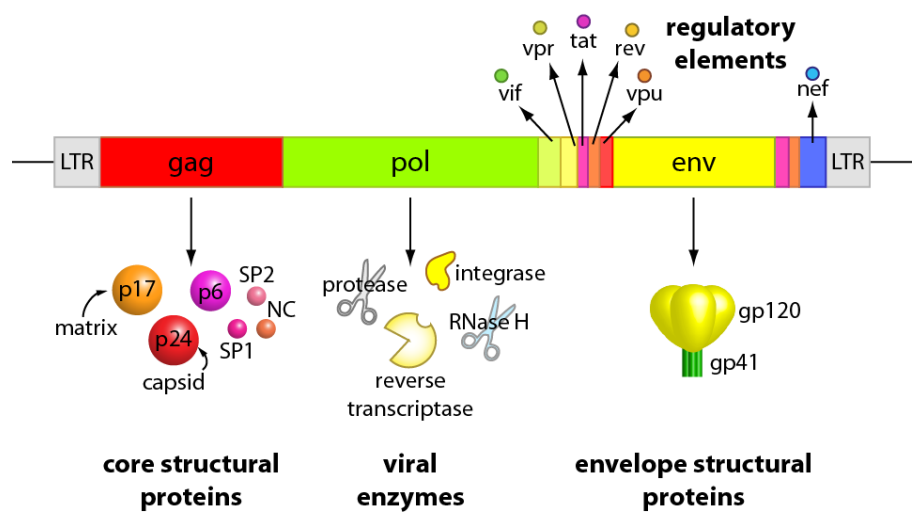

Figure 2. HIV genome. Modified from [5]. The HIV genome consists of two identical singlestranded RNA molecules. The RNA is reverse transcribed into DNA and integrated into the host genome. The viral DNA genome is flanked at both ends by LTR (long terminal repeat) sequences. The 5' LTR region acts as the promoter for transcription of the viral genes. This LTR is followed

by the gag gene, which encodes the core structural proteins. Gag is followed by pol, which encodes the viral enzymes. After pol the genome codes for several small proteins with various functions, known as regulatory elements. Next in the genome comes the sequence coding for the envelope structural proteins, followed by a final 3' LTR.

Table 1. HIV proteins and their function. Modified from [5].

\begin{tabular}{|c|c|c|c|}
\hline Gene & Size ${ }^{*}$ & Protein & Function \\
\hline \multirow[t]{7}{*}{ gag } & & Pr55Gag & precursor of the inner structural proteins \\
\hline & $\mathrm{p} 17$ & matrix protein & forms the inner membrane layer \\
\hline & p24 & capsid protein & forms the conical capsid \\
\hline & & SP1 & spacer, aids assembly \\
\hline & p7 & Nucleoprotein NC & forms the nucleoprotein/RNA complex \\
\hline & & SP2 & spacer, aids maturation \\
\hline & P6 & P6 & involved in virus particle release \\
\hline \multirow[t]{5}{*}{ pol } & & Pr160GagPol & precursor of the viral enzymes \\
\hline & $\mathrm{p} 10$ & protease & $\begin{array}{l}\text { cleaves Gag and Gag-Pol precursor proteins; releases structural } \\
\text { proteins and viral enzymes }\end{array}$ \\
\hline & p51 & reverse transcriptase & transcribes HIV RNA into proviral DNA \\
\hline & $\mathrm{p} 15$ & RNase $\mathrm{H}$ & degrades viral RNA in the viral RNA/DNA replication complex \\
\hline & p32 & integrase & integrates proviral DNA into the host genome \\
\hline \multirow[t]{3}{*}{ env } & & PrGp160 & precursor of the envelope proteins gp120 and gp41 \\
\hline & gp120 & surface glycoprotein & attaches virus to the target cell \\
\hline & gp41 & $\begin{array}{l}\text { transmembrane } \\
\text { protein }\end{array}$ & fuses viral and cell membrane \\
\hline tat & p14 & transactivator protein & activator of transcription of viral genes \\
\hline rev & p19 & RNA splicing regulator & regulates the export of non-spliced and partially spliced viral mRNA \\
\hline nef & $\mathrm{p} 27$ & $\begin{array}{l}\text { negative regulating } \\
\text { factor }\end{array}$ & $\begin{array}{l}\text { influences HIV replication, enhances infectivity, downregulates CD4 } \\
\text { and HLA on target cells }\end{array}$ \\
\hline vif & $\mathrm{p} 23$ & viral infectivity protein & critical for infectious virus production in vivo \\
\hline$v p r$ & $\mathrm{p} 15$ & virus protein $r$ & $\begin{array}{l}\text { component of virus particles, interacts with p6, facilitates virus } \\
\text { infectivity, affects cell cycle }\end{array}$ \\
\hline vpu & p16 & virus protein unique & $\begin{array}{l}\text { facilitates virus particle release, controls CD4 degradation, modulates } \\
\text { intracellular trafficking }\end{array}$ \\
\hline tev & p26 & tat/rev protein & $\begin{array}{l}\text { Tat-Env-Rev fusion protein, regulates the activity of Tat and Rev in } \\
\text { nucleus }\end{array}$ \\
\hline
\end{tabular}

*Numbers correspond to the size of the proteins (p) or glycoproteins (gp) in 1,000 Da. 


\subsubsection{HIV life cycle}

All the viral components, together with elements from the host cell, are used during HIV's replication cycle. For a description of HIV's life cycle, see Figure 3. To infect a cell, HIV requires a $\mathrm{CD} 4$ receptor, and a co-receptor. This co-receptor can be either CCR5 or CXCR4. Novel infections, by any transmission route including intravenous drug use and mother-child, are almost exclusively established by virions that use CCR5 as a co-receptor $[8,9]$. Viruses that can use CXCR4 have been found to evolve in $\sim 50 \%$ of individuals during late stages of disease; $\sim 45 \%$ have viruses that can use both $\mathrm{CXCR} 4$ and $\mathrm{CCR}_{5}$ and $\sim 5 \%$ have viruses that can use CXCR4 only [8].

$\mathrm{CD}_{4}$ and CCR5 are found on CD4 T cells, macrophages, dendritic cells and astrocytes, making them susceptible to HIV infection [5]. Viral replication is, however, by far most efficient in CD4 T cells due to their activated state [5].

Once the virus has bound to a target cell, conformational changes in the viral and host proteins trigger fusion and the contents of the virus are released into the cell cytoplasm. A viral uncoating process ensues, where a complex of viral proteins, consisting of HIV genome, reverse transcriptase, vpu and p17 matrix, travels to the nuclear pores and then gains access to the cell nucleus [8]. In parallel, reverse transcriptase and $\mathrm{RNase} \mathrm{H}$ facilitate the conversion of the viral genome from single stranded RNA to double stranded DNA [5]. Inside the host cell nucleus, viral integrase inserts the HIV DNA into the host genome. This integration finalizes the infection of the cell and establishes a persistent HIV infection [5]. Integration into the host genome allows for the transcription of viral proteins and new strands of HIV RNA genome with the help of the host cell machinery, where the 5' LTR region of the HIV genome acts as a promoter sequence. The integration of HIV's genome into the host's DNA also entails that in resting cells, HIV can lie dormant and invisible to the immune system. HIV that is integrated into the genome of long-lived cells such as macrophages, astrocytes or memory $\mathrm{T}$ cells can persist in a latent state for several years. Activation of such cells results in the production of new infectious HIV particles [8].

Once the new viral proteins and genome have been synthesized, new viral particles assemble, bud off from the host cell and mature. The production of new virions can usually be detected $24 \mathrm{~h}$ after HIV exposure; attachment of virus to the host cell takes 3omin-2h, reverse transcription is completed $6 \mathrm{~h}$ post exposure and integration takes place $12 \mathrm{~h}$ post exposure [5]. 




Figure 3. HIV life cycle, modified from [5]. HIV infection begins with the binding of viral surface glycoprotein gp12O to the $\mathrm{CD}_{4}$ receptor on the host cell. This binding causes a conformational change that allows gp12o to bind the co-receptor CCR5 or CXCR4 on the cell surface. This leads to further conformational changes in gp12O, pg41, CD4 and the co-receptor that cause the formation of a channel between the host cell and the virus, ultimately leading to fusion. Fusion leads to release of the viral capsid into the cytoplasm, where it is taken up by an endosome. $p H$ changes within the endosome then induce the release of the capsid contents, including HIV's genome and various viral enzymes back into the cytoplasm. Here, HIV's RNA genome is reverse transcribed into complementary DNA by HIV reverse transcriptase. HIV RNase $H$ degrades the RNA strand, allowing for the conversion of single-stranded into doublestranded DNA by reverse transcriptase. This DNA is imported into the cell nucleus and the viral integrase inserts HIV's genome into a random location inside the human host cell genome. The

LTR promoter of the viral genome can serve as attachment site for RNA polymerases and a variety of transcription factors, which facilitates synthesis of mRNA coding for viral proteins. In addition, new copies of genomic RNA are synthesized. The viral proteins and genome migrate to the cell surface, where new viral particles are assembled. The viral glycoproteins are incorporated into the host cell membrane before the virus buds off. Finally, after budding, viral proteases cleave HIV's core proteins in appropriate places in order to create the inner and outer capsids in a process called maturation.

\subsubsection{HIV treatment}

There is currently no cure for HIV. There is, however, treatment that can lead to a near-normal life expectancy [10]. This treatment is known as antiretroviral therapy and consists of a combination of drugs that target different stages of HIV's life cycle, limiting HIV replication and thereby progression. As well as preventing HIV disease progression, antiretroviral therapy also reduces viral levels, leading to lower risk of HIV transmission. 
The reverse transcriptase inhibitor azidothymidine (AZT) was the first antiretroviral medicine used to treat HIV infection, approved by FDA in the United States in 1986. AZT is still clinically used today. In addition, AZT is widely used as a means of efficiently inhibiting HIV replication in vitro [11], including by our group.

\subsubsection{HIV damages the host immune system}

HIV's main target cells, where the virus replicates, are CD4 T cells. CD4 T cells are also known as helper $\mathrm{T}$ cells, and they play a central role in coordinating and directing the adaptive immune response. HIV replication inside CD4 T cells is associated with their death, and consequently HIV infection leads to a depletion of this $\mathrm{T}$ cell subset. CD4 T cells in the gut are especially vulnerable to HIV infection, and there is a massive elimination of $\mathrm{CD} 4 \mathrm{~T}$ cells at this site early during HIV disease progression. The $\mathrm{CD} 4 \mathrm{~T}$ cell population in the gut does not recover from this elimination, even in the presence of antiretroviral therapy [12]. The loss of gut CD4 $\mathrm{T}$ cells induces structural damage, and mucosal integrity of the gut is lost leading to the leakage of gut bacterial products from the intestinal lumen into systemic circulation [12]. The leaked gut bacterial products cause immune hyperactivation, which then causes the immune system to become dysregulated and function poorly. A compromised immune system leads to higher susceptibility to other infections and reactivation of latent infections such as herpes, hepatitis and tuberculosis. The immune activation against gut bacteria and other pathogens further activate the immune system, leading to further dysregulation. In addition, the body's attempts to combat the invading pathogens entail the production of more $\mathrm{CD} 4 \mathrm{~T}$ cells, which increases the number of target cells available to HIV. Chronic immune activation is currently accepted as the main pathogenic mechanism of HIV infection and is considered the best predictor of AIDS progression [13].

\subsubsection{HIV disease progression}

HIV disease progression can be divided into three main stages [14]:

1) Acute infection (within 2-4 weeks post infection)

2) Chronic/asymptomatic stage (median $\sim 10$ years)

3) AIDS (leads to death in median $\sim 3$ years without treatment)

Acute infection begins once the virus has established systemic infection and is associated with a high production of virus. HIV replicates explosively within the host's T cells, especially the CD $4 \mathrm{~T}$ cells located in the gut lymphoid structure organs. HIV replication in T cells leads to $\mathrm{T}$ cell death, and $\mathrm{T}$ cell numbers decline. During this time, many, but not all, people develop flu-like symptoms [14]. The high virus levels in the body are associated with a high risk of transmission [14].

After 2-4 weeks, virus levels peak and then decline, reaching a stable set point. $\mathrm{CD} 4 \mathrm{~T}$ cell levels recover, although $\mathrm{CD} 4 \mathrm{~T}$ cell numbers in blood usually do not reach the same levels as prior to infection, and the $\mathrm{CD} 4 \mathrm{~T}$ cell population in the gut remains depleted [14]. The disease then enters an asymptomatic stage, where the infected individual experiences no or mild symptoms. Without treatment, this stage lasts a median of 10 years (with large variation between individuals), and is 
accompanied by a slow gradual decline in $\mathrm{CD} 4 \mathrm{~T}$ cell levels as the virus continues to sustain a low level of replication [14].

Eventually, CD4 T cell numbers are so low, that the immune system collapses and the infected individual becomes susceptible to opportunistic infections. This stage is known as AIDS and is defined as having a CD4 $\mathrm{T}$ cell count below 200 cells $/ \mathrm{mm}^{3}$ (compared to $500-1,600$ cells $/ \mathrm{mm}^{3}$ in healthy individuals) or one or more opportunistic infections [14]. In absence of treatment, death occurs approximately one year after the infected individual presents with their first opportunistic infection [14]. An overview of HIV disease progression can be found in Figure 4.

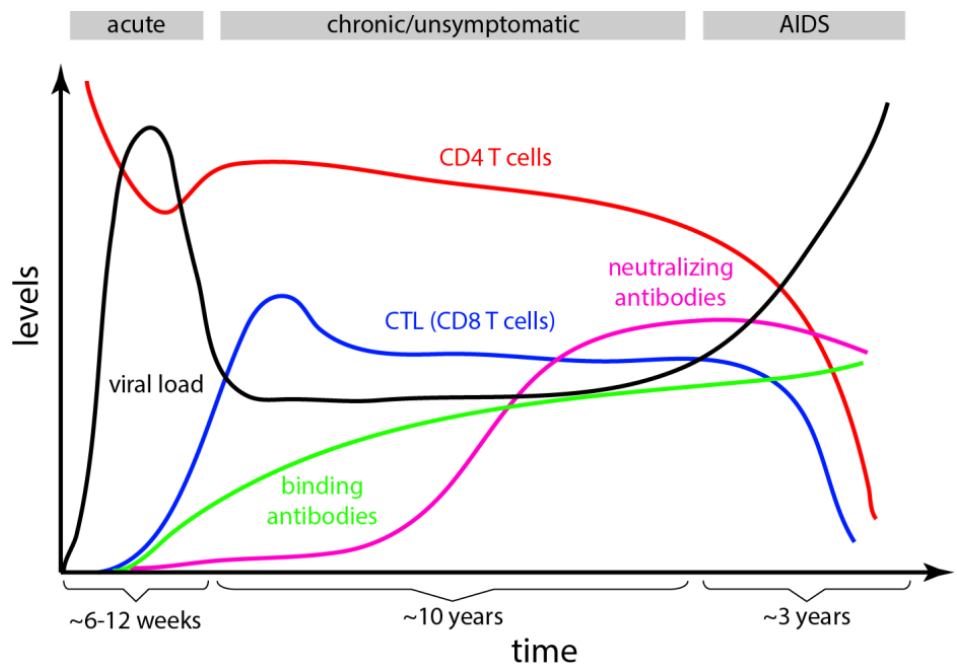

Figure 4. HIV disease progression. During the acute phase of HIV infection, there is massive viral replication, especially in the $\mathrm{CD}_{4} \mathrm{~T}$ cells of the gut. Eventually, viral levels peak, decline and then stabilize. The size of the viral peak, as well as the level at which viral levels stabilize are predictive of disease progression, i.e. how fast the infected individual will progress towards AIDS. It is believed that HIV-specific cytolytic CD8 T cells (CTL) can be responsible for the initial decline in viremia. Antibodies usually appear later during disease progression, when virus levels have already stabilized. During the chronic stage of HIV disease progression, there is a low level of viral replication, associated with a gradual decline in number of $\mathrm{CD} 4 \mathrm{~T}$ cells. Once CD4 T cells levels reach a critical level, the entire immune system collapses and the body can no longer control HIV replication and $\mathrm{CD}_{4} \mathrm{~T}$ cell levels plummet. This immune collapse leaves the body susceptible to other pathogens, including those that normally do not cause disease (opportunistic infections), and eventually leads to death.

\subsubsection{HIV control}

Some individuals exhibit natural HIV control. These can be defined as follows:

1) HIV-exposed seronegative - individuals who fail to become infected despite multiple exposures to HIV. HIV-exposed seronegative individuals can for instance be found among uninfected partners in discordant couples and among sex workers in regions with a high HIV prevalence [15]. 
2) Long-term non-progressors - individuals who remain asymptomatic for more than 10 years, i.e. do not progress to AIDS, with low viral loads in the absence of antiretroviral therapy [16].

3) Elite controllers - a subgroup of long term non-progressors who have HIV RNA concentrations under 50 copies/mL in blood, i.e. viral levels so low that they are below the detection threshold for some assays [17]. It is estimated that approximately 1/300 HIV infected are elite controllers [17].

Susceptibility to HIV infection and disease progression can be affected by host and viral genetic factors, as well as the circumstances during exposure such as the presence of co-infections. Studies have estimated that viral genetic factors explain 29-60\% of the rate of HIV disease progression [18], meaning factors in the host likely play a very important role for HIV pathogenesis. Naturally, populations that exhibit HIV control have been the targets of extensive studies, in attempts to decipher correlates of protection and what characterizes good immune response against HIV.

Determining the factors that contribute to HIV control is problematic - studies tend to find that individuals with a slow disease progression have better immune function irrespective of the immune component evaluated. HIV disease progression is associated with chronic immune hyperactivation, which leads to immune dysfunction and immune exhaustion. It is therefore difficult to prove the causal relationship between the functionality of a specific immune cell type and the rate of progression towards AIDS, i.e. whether better immune function leads to slower progression or whether slower progression leads to less detrimental effects on the immune function.

Given that the viral load and the viral set point during acute infection are strong predictors of disease progression [19], host innate immune factors in the host likely play an important role in HIV control.

In addition to studying human HIV controllers, there has been research to attempt to explain the difference in SIV disease outcome between species of monkeys that are natural SIV hosts (i.e. where the virus is endemic) and those that are not, as natural hosts of SIV generally do not progress to AIDS [6]. Although there still is no complete explanation concerning the ability of some monkey species to control SIV, it is believed that early events during infection are determinants [6]. Among other things, natural SIV hosts manage to avoid microbial translocation from the gut lumen, either by preventing or by repairing damage to the gut epithelium, and maintain homeostasis of their immune cell populations, including NK cells, monocytes, macrophages, dendritic cells, and various T cell populations.

\subsection{HIV transmission}

\subsubsection{HIV transmission routes}

The vast majority of HIV transmission occurs at the mucosal surfaces of the genital and rectal tracts after sexual intercourse with an infected partner [20]. Other infection routes are associated with contact with infected blood. Vertical transmission, i.e. from infected mother to child, can also occur; HIV is present in the amniotic fluid and without treatment there is approximately $25 \%$ risk of vertical transmission. In addition, breastfeeding is also associated with a transmission risk; 
one study found that 2 years of breastfeeding resulted in approximately $15 \%$ risk of HIV transfer to the child [21]. For an overview of transmission routes and the associated per-act transmission risk, see Table 2.

In heterosexual discordant relationships, male-to-female HIV transmission is approximately 8-fold greater than female-to-male transmission. It is estimated that $30-40 \%$ of new infections occur through HIV exposure of the female genital tract to virus-containing semen, making the female genital tract the most common site of HIV transmission [22]. Another very important portal of HIV entry is the analrectal mucosa. It has been estimated that up to $40 \%$ of heterosexual individuals and up to two thirds of men who have sex with men participate in anal intercourse [23]. Per-act transmission is 10 to 100 -fold higher in colorectal compared to vaginal mucosa [24]. Overall, men who have sex with men are the population who have the highest risk of contracting HIV, both in developed and developing countries [23].

HIV epidemiology and key populations affected vary according to geographical location. 70\% of all HIV infected individuals can be found in Sub-Saharan Africa, where girls and young women represent $71 \%$ of young people living with HIV. In this region, the heterosexual route is by far the most common mode of HIV transmission, accounting for $80 \%$ of all incidence [25]. In contrast, in western Europe and North America, men who have sex with men account for approximately $50 \%$ of all new HIV infections, while in Eastern Europe and Central Asia, over half of HIV incidence is attributed to drug injection [25].

The reasons behind this diversity in epidemiology are complex, and have historical, political, financial as well as behavioral aspects. It has been suggested that the number of concurrent sexual partners is one factor that has a substantial impact on HIV epidemiology [26].

Table 2: HIV transmission routes: per-act transmission risk. Modified from Patel et al [24].

\begin{tabular}{rr} 
Route & Risk (per exposure) \\
\hline blood transfusion & $93 \%$ \\
\hline mother-child (without treatment) & $25 \%$ \\
\hline needle sharing (injection drugs) & $0.6 \%$ \\
\hline percutaneous (needle-stick) & $0.2 \%$ \\
\hline receptive anal intercourse & $1.4 \%$ \\
\hline insertive anal intercourse & $0.11 \%$ \\
\hline receptive penile-vaginal intercourse & $0.08 \%$ \\
\hline insertive penile-vaginal intercourse & $0.04 \%$ \\
\hline biting & negligible \\
\hline
\end{tabular}

\subsubsection{Anatomy at mucosal sites where HIV is transmitted}

Mucosal surfaces can be divided into two main types - type I, which consist of a single thin monolayer of polarized columnar epithelial cells joined by tight junctions and type II, which consist of an avascular multilayered squamous epithelium that is mainly composed of keratinocytes [27]. The upper female genital tract (endocervix) and the rectum represent type I mucosa. In contrast, the lower female genital tract (vagina, ectocervix), the anus, as well as the inner foreskin are type II mucosa [27]. The transition between the two types of mucosal surfaces is known as the squamocolumnar junction or transformation zone and occurs between the endo- 
and ectocervix (transformation zone) and between the anal canal and the rectum (dentate line) [27].

The epithelium of type II mucosa is interspersed with Langerhans cells, which are a dendritic cell type unique for this mucosa [27]. The layer of connective tissue below mucosa is referred to as the lamina propria [27]. This layer contains immune cells including conventional myeloid dendritic cells and T cells, blood capillaries and lymph vessels. An overview of the composition of type I and type II mucosa can be found in Figure 5.

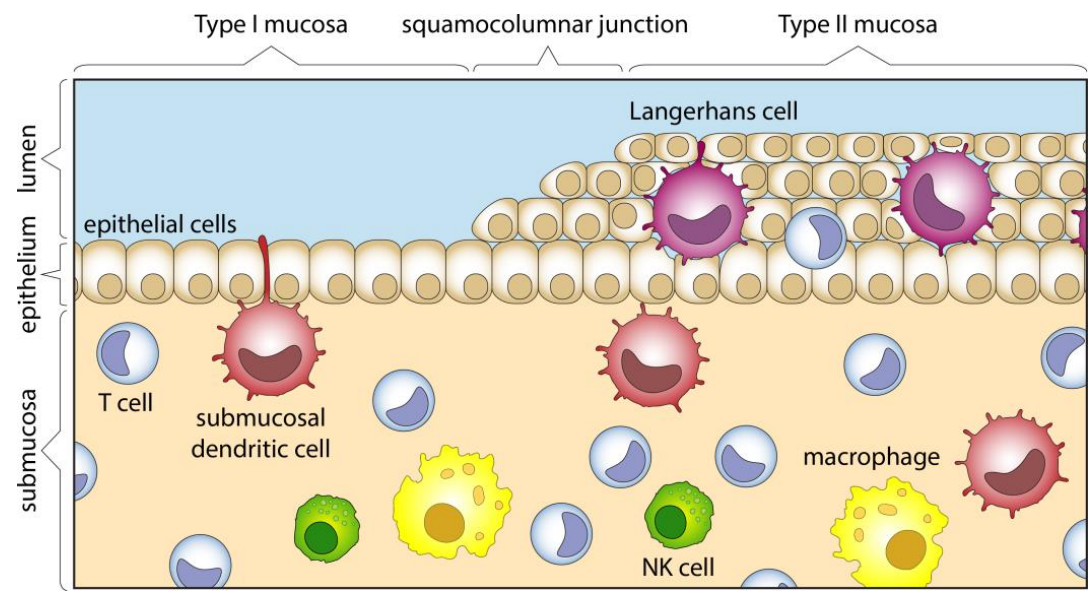

Figure 5. Composition of type I and type II mucosa. Type I mucosa is covered by a single layer of epithelial cells, while type II mucosa has a multi-layered epithelium interspersed with Langerhans cells. The submucosa contains various immune cells, including submucosal myeloid dendritic cells, T cells, macrophages and NK cells.

HIV infection is initiated by a small number of transmission events across the mucosal surface [28] - often it is a single viral variant that establishes infection in the new host [29].

In the female reproductive tract, HIV transmission can occur throughout the genital mucosa [30]. The exact relative contribution of each site, i.e. vagina, endoand ectocervix to successful transmission remains unknown. While the single-layer epithelial lining of the endocervix is easiest for HIV to cross, the ectocervix and vagina have a much higher relative surface area, and have therefore been suggested by some to account for the majority of transmission events [30]. However, according to others, the majority of loci of infected cells post intravaginal exposure are located in the endocervix [31].

The much higher per-act transmission colorectal compared to vaginal mucosa can in part be attributed to the single epithelial layer of the rectal mucosa and a larger number of micro-abrasions caused by intercourse. However, the microenvironment at this site also renders the target cells present more permissive to infection [23]. 


\subsubsection{Dendritic cells are antigen presenting cells}

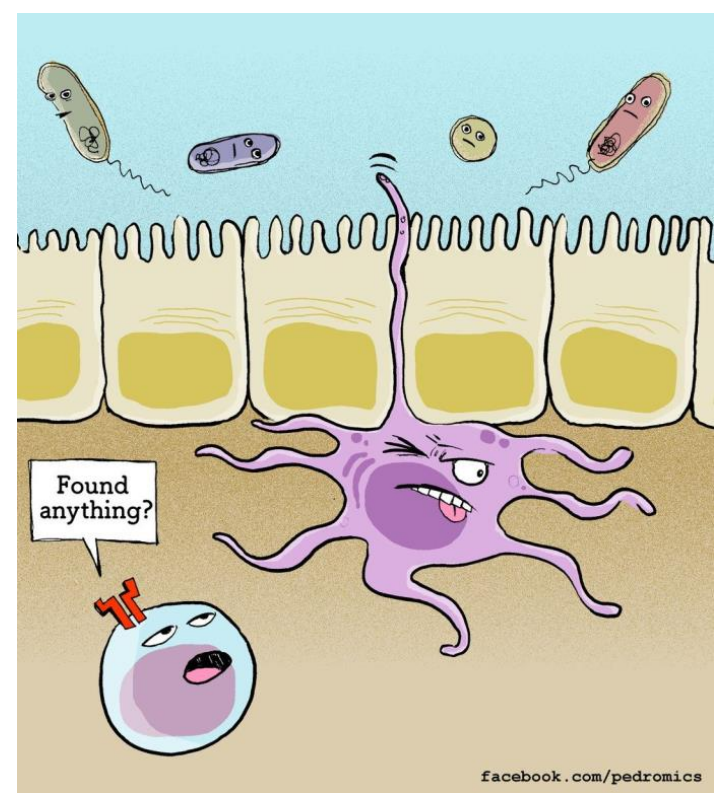

Figure 6. Dendritic cells in the mucosa survey the periphery, searching for pathogens. Below, antigen specific T cells await stimulation. Image reprinted with permission from the artist, Pedro Veliça.

Dendritic cells are professional antigen presenting cells [32]. They are key determinants in both innate and adaptive T cell-mediated immune responses [33]. There are two main types of dendritic cells, divided according to hematopoietic origin; myeloid and plasmacytoid. Myeloid dendritic cells can be further divided into Langerhans cells and conventional dendritic cells (sometimes simply referred to as myeloid dendritic cells) [34]. Dendritic cells exist in immature and mature forms [34].

Myeloid dendritic cells survey the periphery of the human body, including all mucosal sites where HIV transmission occurs, for signs of danger such as pathogens, see Figure 6. They express a number of pattern recognition receptors (PRRs) that allow them to detect molecules associated with danger. An overview of the PRRs expressed by dendritic and related cell types can be found in Figure 7. A dendritic cell that encounters a pathogen usually picks up the pathogen and processes it so that it can present pathogen-derived antigens to T cells. This is associated with a maturation process where the cell downregulates its ability to capture new pathogens, and instead upregulates its ability to interact with and stimulate T cells. Maturation is also associated with migration to a lymph node, which is the major site where $\mathrm{T}$ cells are located. The exact PRRs triggered, in combination with other factors that were present in the microenvironment when PRR stimulation occurred, will determine the quality as well as the type of adaptive $\mathrm{T}$ cell response that will be induced by the dendritic cell, see Figure 8. Importantly, 
as well as acting in an immunogenic manner, dendritic cells can also induce tolerance, and they are vital for the avoidance of self-immunity [35].

In their resting state, plasmacytoid dendritic cells are predominantly found in the blood. They can, however, be recruited to sites of foreign antigen exposure or inflammation, where they primarily provide antiviral defense by secretion of large quantities of type I interferon. In this setting, they can also stimulate and present antigen to T cells [36].

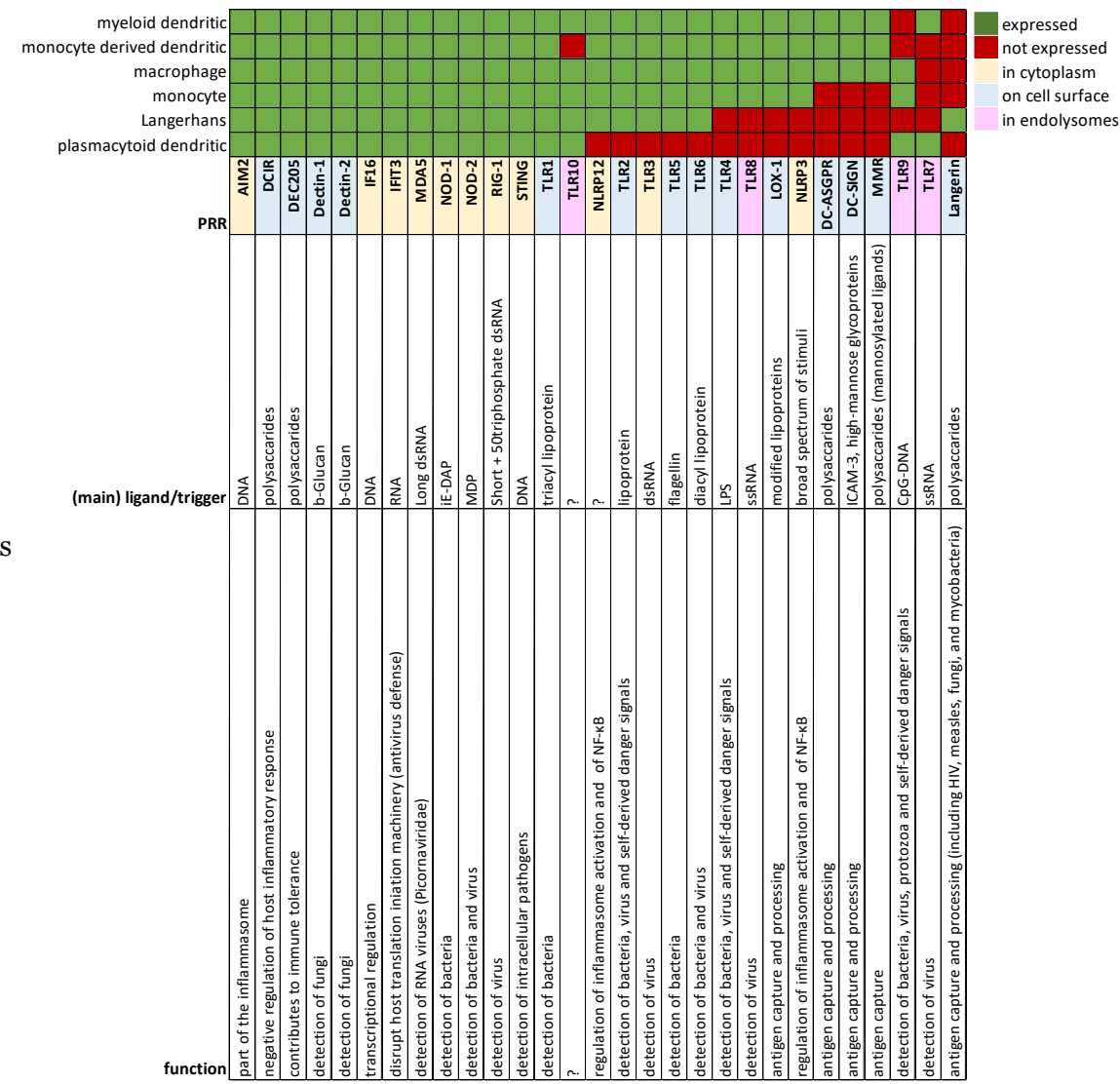

Figure 7. Pattern recognition receptors in dendritic cells and related cells. Note that cells have been scored as positive for expression, even if receptor expression is low or only inducible. Data from [37-47]. 


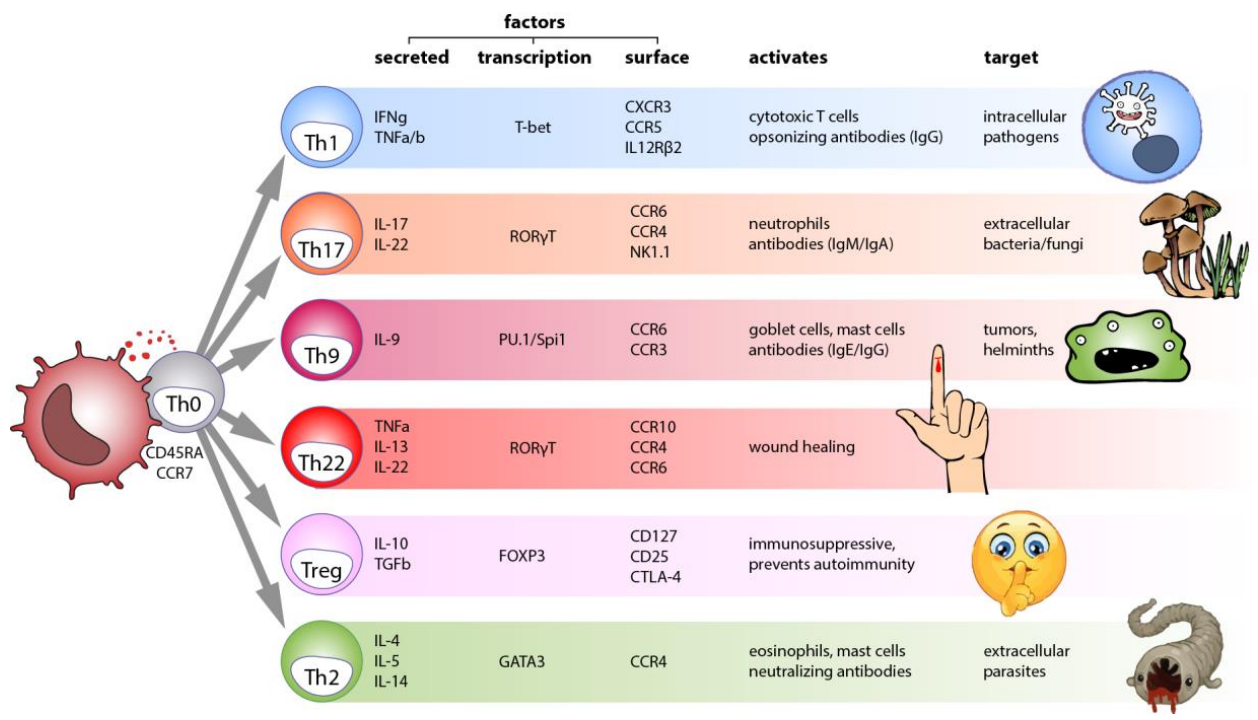

Figure 8. Thelper cell (Th) polarization. Depending on the stimuli that a dendritic cell has been activated by, it can push a naïve CD4 T cell (Tho) to differentiate into different directions to create a relevant immune response. This is known as $T$ cell polarization, and the cells that are fully differentiated are called effector cells. The polarized Th cells interact with almost all immune cell types, orchestrating and directing the adaptive immune response. This figure shows a simplified classification of the different Th types that can be elicited, their hallmark cytokines and their main type of target pathogen or function.

\subsubsection{HIV reaches the submucosa via epithelial cells or dendritic cells}

Studies of the capacity of HIV to cross the epithelium have shown that approximately $0.05 \%$ of virions added on the top side of an epithelial layer transmigrate through [48]. Virions could be sequestered within the epithelial cells, and virus released up to 9 days post exposure could remain infectious [48].

Another mechanism that contributes to the transfer of HIV from one side of the epithelial barrier to the other is dendritic cells. Langerhans cells have been shown to extend their dendrites towards the epithelial surface in genital and rectal mucosa and are able to pick up HIV and transfer it across the epithelial barrier. The importance of this mechanism is supported by the fact that male circumcision is associated with $60 \%$ reduction in HIV infection rates [49]: the foreskin is especially rich in Langerhans cells, and it has also been reported that Langerhans cells in the glans penis are closer to the surface of uncircumcised versus circumcised penises [50].

Conventional submucosal dendritic cells also contribute to HIV transfer, especially in type I mucosa where the epithelial cell layer is only one cell thick. Submucosal dendritic cells express tight junction proteins, and have been shown to penetrate through the epithelium to sample pathogens on the other side, see Figure 6 [51]. 


\subsubsection{Dendritic cells pick up HIV during sexual transmission}

As outlined above and proposed by others, dendritic cells are one of the first immune target cells to detect HIV during sexual transmission [52]. In an in vivo SIV macaque model, it was found that the virus crossed the epithelial barrier 60 minutes post intravaginal SIV exposure, primarily infecting intraepithelial dendritic cells [53]. Dendritic cells carrying the virus could then be detected in the draining lymph nodes of the animals as early as $18 \mathrm{~h}$ post exposure [53].

When dendritic cells come into contact with HIV, the virus is taken up by a mechanism that bypasses the regular endosome/lysosome pathway - instead of becoming broken down and processed for antigen presentation, the viral particles are sequestered in a compartment that allows them to remain infectious [54]. Virus particles taken up in this manner can then be very efficiently transferred to $\mathrm{CD} 4 \mathrm{~T}$ cells, in a process called trans infection [54]. The dendritic cells can also become infected themselves, and even though they do not support high levels of replication, they are capable of transferring de novo produced virus particles to T cells [54].

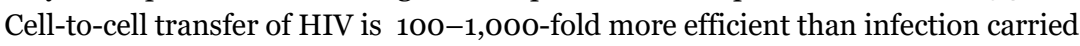
out by cell free virions [55].

There has been some controversy concerning whether Langerhans cells can be infected by HIV or not. However, some of the discrepancy in results obtained by different groups can be attributed to the technique used to isolate the Langerhans cells: using the enzyme trypsin to dissociate Langerhans cells from the surrounding tissue also cleaves the receptor $\mathrm{CD}_{4}$ (required for HIV infection) from the cell surface [56].

Once the virus has crossed the epithelial barrier, immune cells are recruited to the site. The migration of immune cells to and from the primary site of infection is essential for systemic infection, as blocking immune cell trafficking averts viral spread [57]. Importantly, the migration of dendritic cells carrying HIV to the draining lymph nodes is vital for systemic infection [53].

\subsubsection{Dendritic cells determine adaptive responses to HIV}

As well as playing a key role in $\mathrm{T}$ cell infection and viral spread, dendritic cells are also essential for the formation of protective immune responses to HIV. Studies show that the early events during HIV transmission determine the viral set point and the rate of disease progression, and it has been suggested that dendritic cells play a central role in these events [33]. Dendritic cells generated from elite controllers became more mature and secreted more interferon than dendritic cells from typical HIV patients, allowing them to stimulate better HIV specific CD8 T cell responses [28]. This is in accordance with research that indicates that CD8 T cells are the cells responsible for the initial viral control following HIV infection [58].

\subsubsection{NK cells can kill infected dendritic cells or help them to mature}

Natural killer (NK) cells are the most effective killing units of virus infected cells of the innate immune system. A limited number of NK cells are present as resident cells in mucosa at the sites of HIV transmission, but they can be rapidly recruited to 
the site of infection [59]. NK cells have the ability to control HIV replication, and their activity is associated with protection from infection [60, 61].

NK cells are suggested to be able to eradicate infection at a very early stage during HIV exposure, before the virus has established systemic spread, and can contribute to the lack of infection in highly exposed seronegative individuals [62].

In addition to recognizing and eliminating virus infected cells in order to avoid viral spread, NK cells also play a very important role in the formation of adaptive immune responses via NK-dendritic cell crosstalk. Dendritic cells exposed to HIV often do not undergo proper maturation, and cells that are not fully mature often lead to defective $\mathrm{T}$ cell priming. NK cells have the ability to detect partially mature dendritic cells and to eliminate them, in a process called "dendritic cell editing". This process has been shown to enhance the expansion of antigen specific cytotoxic T cells [63], which are important effector cells involved in HIV control.

In cases where the dendritic cells are not lysed by the NK cells that they interact with, the NK cells can induce further activation and maturation of the dendritic cell, giving them the ability to prime more robust $\mathrm{T}$ cell responses [64]. This interaction is also associated with activation of the NK cell.

A simplified figure showing the roles of dendritic cells, T cells and NK cells during mucosal transmission of HIV can be found in Figure 9.
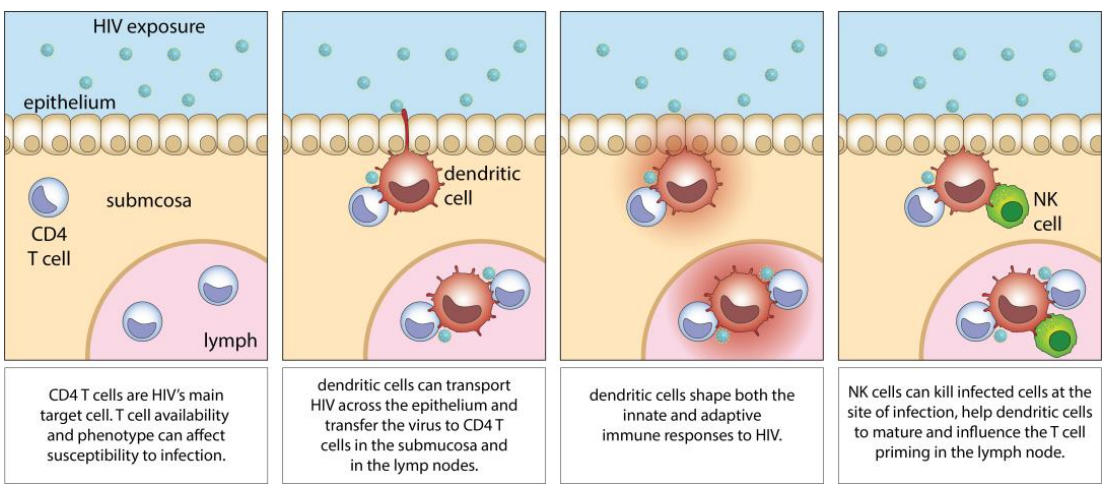

Figure 9. Role of dendritic cells, $T$ cells and NK cells during HIV transmission.

Dendritic cells are key determinants of innate and adaptive immune responses after HIV exposure. Dendritic cell interactions with NK- and T cells are important for the shaping of these responses.

\subsection{HIV susceptibility and control}

\subsubsection{HIV transcription}

Generation of HIV derived RNA, which is used to generate new viral proteins and new copies of the viral genome, is dependent on the host cell transcription machinery. It is also dependent on the viral protein Tat, without which the host RNA polymerase II disengages after the transcription of part of the LTR known as trans activation response element (TAR) [65].

In order to regulate its transcription, HIV utilizes host factors as repressors or activators/enhancers of transcription, which can bind to different parts of the LTR 
and act as transcription inhibitors or as promoters [65]. In resting cells, HIV is usually in a latent state, where transcription is absent. During cell activation, activators of transcription, typically host transcription factors associated with inflammatory and antiviral responses such as $\mathrm{NFk} \beta$ and/or interferon regulatory factors (IRFs), are recruited to the LTR and act as a promotor for viral transcription [65]. An overview of HIV transcriptional regulation can be found in Figure 10.

The fact that the same transcription factors that are necessary in order to mount responses that inhibit viral replication and other infections also aid in viral replication is problematic for the host. Typically, IRFs associated with antiviral responses have a lower threshold for transcription of antiviral genes than for transcription of the HIV genome, i.e. lower levels of IRFs can maintain antiviral responses while disfavoring HIV replication [66]. In contrast, inflammation mediated by $\mathrm{NFk} \beta$ usually has a direct positive relationship to HIV transcription, with higher $\mathrm{NFk} \beta$ levels leading to higher HIV replication [67]. HIV transcriptional regulation is complex and can be affected by multiple factors including cell type, cell phenotype and the microenvironment.
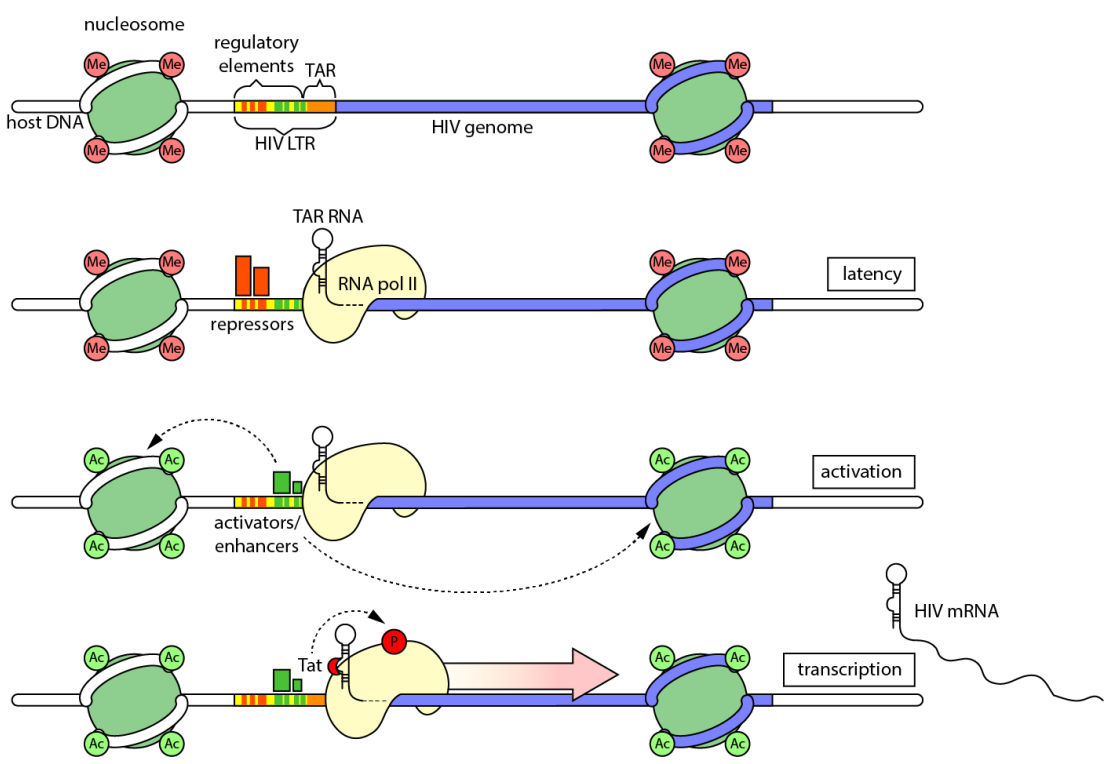

Figure 10. HIV transcriptional regulation. Modified from [65]. In resting cells, HIV is latent. The host RNA polymerase can be recruited to the HIV LTR and can transcribe the nascent TAR RNA (trans activation response element) - a sequence located at the 5'end of the LTR that forms a hairpin structure. However, transcriptional repressors bound to the HIV LTR negative regulatory elements result in pause of RNA polymerase II. The surrounding host DNA is often inaccessible due to histone methylation. During cell activation, transcriptional activators and enhancers - typically $N F k \beta$ or IRFs - are recruited to the LTR, and histone modifiers remove the methyl groups from the histones, making the chromatin more accessible. HIV Tat binds to the TAR RNA and leads to the phosphorylation of RNA polymerase II, allowing it to move along the DNA strand and transcribe viral $m R N A$. 


\subsubsection{HIV replication in dendritic cells: PRRs and restriction factors}

There are a number of PRRs in dendritic cells that can be triggered by HIV components. When HIV is taken up by endocytosis, HIV-derived single stranded RNA serves as a ligand for TLR8 [68]. TLR8 detects ligands present in endosomes and relays a signal into the cell via the adaptor MyD88, IRAKs and TRAF6. The exact TLR8 signaling can vary depending on the specific ligand, but typically, TLR8 activation leads to the activation of MAPKs, $\mathrm{NF \kappa} \beta$ and/or IRF transcription factors [69].

TLR8 usually leads to robust inflammatory and antiviral responses, and TLR8 mediated signaling has the ability to inhibit HIV infection [70]. Importantly, studies report that HIV subverts TLR8 signaling, and that as well as suppressing innate immune responses, this leads to inhibition of viral degradation and allows for more efficient trans infection [71].

Cytosolic DNA can be detected by cGAS and IFI16, which in turn activate STING and downstream interferons and cytokines [72]. Studies suggest that transcribed HIV DNA that triggers these responses, as reverse transcriptase inhibitors block the production of interferons, whereas integrase inhibitors do not [72].

SAMHD1 is a protein that inhibits the replication of retro- and DNA viruses (including HIV) by depleting the intracellular pool of dNTP, thereby limiting the available building blocks to synthesize DNA [73]. A related mechanism is mediated by TREX1, which is an exonuclease that degrades reverse-transcribed HIV DNA in the cytoplasm [74]. The restriction of HIV replication in dendritic cells and other myeloid cells has been attributed to SAMHD1 and TREX activity [73]. However, the activity of SAMHD1 and TREX1 also entail that there is less viral DNA accessible for sensing by IFI16 and cGAS, which in turn entails that IFI16 and cGAS fail to trigger interferon- and inflammatory pathways [75].

In addition to SAMHD1 and TREX1, the enzyme APOBEC $3 \mathrm{G}$ also targets HIV reverse transcription, by causing hypermutation of the viral genome [76]. Although $\mathrm{APOBEC}_{3} \mathrm{G}$ acts during the early phases of HIV's life cycle, antiviral activity is observed only if $\mathrm{APOBEC}_{3} \mathrm{G}$ is expressed in the cell from which the virion is derived, i.e. only if it has been incorporated into the virus particle [77].

Other restriction factors are directed against later stages in HIV's replication cycle. Once HIV's genome is integrated into the cell and viral proteins are produced, assembly must occur, and HIV's glycoproteins must be incorporated into the viral envelope. Myeloid cells have been shown to contain the membrane bound protein RING-CH 8 (MARCH8), which retains HIV's glycoproteins intracellularly and thereby prevents viral envelope assembly [78]. The interferon-inducible protein $\mathrm{GBP}_{5}$ is another factor that interferes with viral assembly by hampering processing, trimming and incorporation of the HIV glycoproteins into the viral envelope [79].

In addition to viral structural proteins, the production of new infectious virions requires copies of the viral genome i.e. transcribed viral RNA. This RNA is also a potential target for cell PRRs, and has been suggested to trigger signaling via RIG1, which then leads to antiviral responses via IRF1 and IRF7 [80].

Once the new viral particles have been assembled, they need to bud off from the host cell. Tetherin (BST2) is an interferon-inducible transmembrane protein that restricts HIV particle by forming a link between the host and virus bilayer, which prevents the HIV particles from being released [81]. 
Lastly, the interferon inducible restriction factor IFITM is a factor that can affect multiple stages of HIV replication. IFITM is a membrane protein that can either be incorporated into the viral envelope, or present in the host cell surface. Either way, the presence of IFITM inhibits viral fusion with the host, as well as cell-to-cell viral transfer [82].

Although there are multiple HIV restriction factors that suppress HIV replication in myeloid cells, HIV has evolved many mechanisms to circumvent these (reviewed in [83]). The result is a balance, where the virus is able to sustain a low level of replication within the cell, while avoiding to trigger significant antiviral and inflammatory responses [83].

\subsubsection{Host genetic factors found to influence HIV control}

The level to which viral levels are suppressed during acute infection, the viral set point, is predictive of disease progression, with a lower set point being prognostic of slower progression towards AIDS [16]. Host genetics are estimated to explain 25\% of viremia set point variance in HIV infected individuals [84].

Hundreds of studies have been conducted in the search of the host genetic determinants of HIV acquisition and disease progression. Most of these have investigated pre-defined candidate genes, but 5 large genome wide association studies have also been performed (summarized in [84]).

The lack of infection in HIV exposed seronegative individuals has in some cases been explained by a mutation in HIV coreceptor CCR5, which renders HIV unable to fuse with target cells [85]. This variant was found to be present in the Caucasian population with a frequency of 0.081, and is very uncommon in people of African or Asian ancestry [85].

One study found that polymorphisms in HLA alleles ( $\mathrm{B}^{*} 53: 01, \mathrm{~B}^{*} 14: 01$, and $\mathrm{B}^{*}$ 27:03) and TLR (TLR2 rs3804100 and TLR7 rs179012) explained 13\% and 6\%, respectively, of variance in viral set point [86]. HLA-alleles are important in the killing of infected cells by cytotoxic CD8 T cells and by NK cells, which indicates that these cells are important for host control of HIV infection [16]. Indeed, cytotoxic CD8 responses have been suggested to be responsible for the drop in viremia during acute infection [16]. The importance of CD8 T cell responses is also supported by the presence of HIV-specific CD8 T cell responses in HIV some exposed uninfected individuals, which has been suggested to be a marker of HIV infection that has been aborted prior to systemic spread [16].

NK cell mediated antiviral activity is believed to be of great importance for the host ability to control HIV infection, especially in the early stages of HIV infection [61]. Polymorphisms in the killer cell immunoglobulin-like receptors (KIR), which interact with the HLA molecules to enable the recognition of virally infected cells, have also been found to affect HIV control [84]. Since these two receptors interact, certain combinations of HLA and KIR variants have been found to be positively or inversely associated with HIV viral control [84].

In addition to the above-mentioned study that found associations between TLR2 and TLR7 polymorphisms and viral set point, polymorphisms in other TLRs, including TLR3, TLR4, TLR8 and TLR9 have been found to be predictive of host ability to control HIV infection [87]. Although the exact mechanism behind this has 
not been identified, it reflects the importance of the innate immune response for viral control.

An overview of the roles of HLA, KIR and TLRs in HIV control can be found in Figure 11.

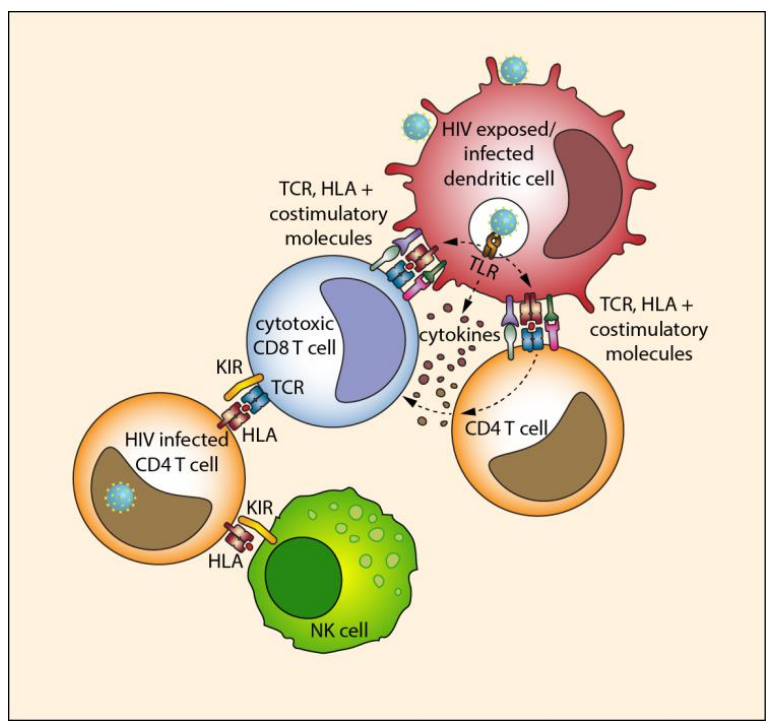

Figure 11. Role of HLAs, KIRs and TLRs in HIV control. Polymorphisms in HLA alleles as well as in TLR- and KIR receptors have been found to be predictive of HIV control. HLA molecules present peptides, including peptides derived from HIV. HLA molecules carrying peptides can interact with receptors on other immune cells such as T cells and NK cells to activate them, and polymorphisms in HLA alleles can affect the threshold of this activation. KIR receptors can interact with HLA molecules, and influence the signal transmitted, for example to trigger NK- and cytotoxic $T$ cell mediated killing of an infected cell. TLR receptors play an important role in detecting pathogens and mounting innate immune responses. In addition, TLR signaling in dendritic cells leads to the upregulation of costimulatory molecules and the secretion of cytokines that contribute to T cell activation. The costimulatory molecules and cytokines present during antigen presentation will affect both $C D 4$ and $C D 8 T$ cell activation directly. The activated $\mathrm{CD}_{4} \mathrm{~T}$ cells can further stimulate HIV specific CD8 T cells and influence their effector functions.

\subsubsection{Dendritic cells that encounter HIV should mount inflammatory and antiviral responses}

HIV-exposed seronegative individuals have been shown to have higher responsiveness to TLR8 ligands [88]. It has been suggested that this represents a virus-exposure-induced innate immune protective phenotype against HIV, that is also associated with a more robust release of immunologic factors and the induction of stronger adaptive antiviral immune responses [88].

Recent studies suggest that the initial events and the inflammatory profile during acute retroviral exposure across mucosal surfaces are predictive of the viral load set point and the rate of disease progression [89]. Dendritic cells play a central role in 
shaping the initial responses after HIV exposure, making them important determinants of disease outcome and progression.

\subsubsection{HIV replication in T cells and markers of T cell permissiveness to HIV infection}

Individuals and populations of $\mathrm{T}$ cells within the same individual differ in their susceptibility to HIV infection and the levels of viral replication that they can support. One study found that approximately half of the variance in virus production between cells isolated from different individuals could be attributed to factors affecting viral entry and half to factors affecting viral transcription [90].

Importantly, $\mathrm{T}$ cells that express the mucosal homing receptor $\alpha 4 \beta 7$, such as $\mathrm{T}$ cells in the gut and cervix, are much more susceptible to HIV infection. Interaction of HIV envelope protein gp120 with the $\alpha_{4} \beta 7$ receptor aids fusion and triggers signaling events that favor viral replication This interaction also facilitates spread between $\mathrm{T}$ cells through the formation of virological synapses [91].

Other CD4 T cell phenotypes associated with HIV infection include:

- Cells with an activated phenotype i.e. proliferating cells are more susceptible than resting cells. Such cells often express markers such as CD38.

- Cells with a central memory phenotype - cells that express both CCR7 and CD45RO but not CD45RA.

- Cells that express CCR4 and CXCR3, receptors associated with the migration to inflamed tissue.

- Cells that express CD25, an activation marker often expressed by Treg cells.

- Cells that express the markers CD28, CD63 and CD317 [92]

It is important to note that the entry of HIV into T cells, i.e. how easily an individual's cells can be infected ex vivo, does not correlate with HIV acquisition [93]. Nevertheless, the ability of T cells to be infected and to support HIV replication likely impacts pathogenesis.

\subsubsection{Effect of HSV2 on HIV susceptibility}

As mentioned above, the presence of inflammation and immune activation facilitates HIV replication by facilitating viral transcription. One source of inflammation and immune activation are ongoing infections. HIV susceptibility during sexual transmission of HIV is greatly enhanced in the presence of other sexually transmitted diseases. Herpes simplex virus 2 (HSV2), a virus that causes genital herpes, plays an important role in HIV epidemiology.

HSV2 is associated with an up to 3 times higher risk of contracting HIV during a sexual encounter with an infected individual [94]. HSV2 has a very high prevalence in the population, ranging between $10-80 \%$ in individuals 15 or older, with the highest prevalence in sub Saharan Africa [95], and is therefore a very important factor contributing to HIV spread.

Inflammation from an ongoing infection will recruit $\mathrm{CD} 4 \mathrm{~T}$ cells to the site, increasing the amount of HIV target cells. Inflammation and presence of CD4 T 


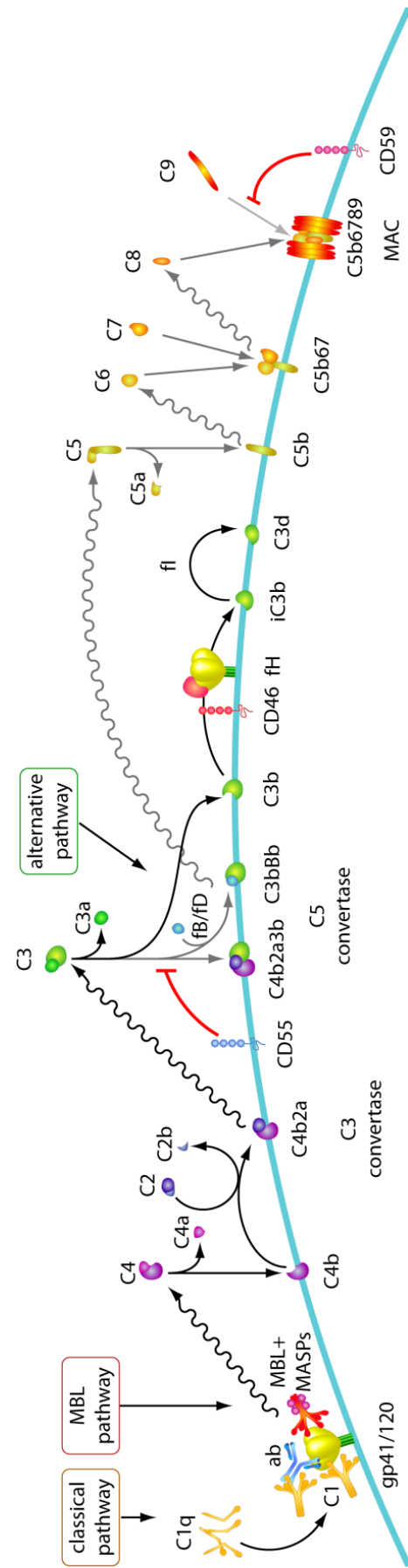

Figure 12. The complement system. cells has also been shown to trigger release of HIV virions sequestered within the epithelium, i.e. to increase the number of virions that cross the epithelial barrier [48].

Importantly, HSV2 infection increases HIV susceptibility even when the disease is in a latent state, i.e. when there are no active lesions [96]. Immune cells persist at the sites of HSV2 reactivation for months after the lesions have healed, and these cells also have an altered phenotype that is more permissive to HIV infection, including the upregulation of $\alpha_{4} \beta 7$ on mucosal $T$ cells [96].

In addition to affecting target cells and the microenvironment in the mucosa, HSV2 also can directly infect dendritic cells, which will have profound effects on their responses to HIV [97].

\subsection{HIV complement opsonization}

\subsubsection{The complement system}

The complement system is part of the innate immune response. It consists of more than 20 proteins found in blood and other body fluids, normally as inactive precursors. These precursors can be activated through three different routes - the classical, the mannosebinding lectin (MBL) and the alternative pathways - which all converge at the activation and cleavage of complement protein $\mathrm{C}_{3}$. Cleavage of $\mathrm{C}_{3}$ to $\mathrm{C}_{3} \mathrm{~b}$ exposes an unstable thioester bond, which then reacts very quickly with available amine or hydroxyl groups to covalently attach $\mathrm{C}_{3} \mathrm{~b}$ on a target surface [98]. A cascade of complement protein recruitment and cleavage is triggered, ultimately leading to the formation of the terminal membrane attack complex (MAC) - essentially a pore in the target membrane that causes lysis [99]. In addition to lysis, complement activation also leads to the recruitment of inflammatory cells, improves antigen presentation, and lowers the threshold for B cell stimulation [100]. These mechanisms are vital for the clearance of many pathogens [101]. 
The alternative complement pathway is constitutively active due to spontaneous hydrolysis of $\mathrm{C}_{3}$. Consequently, regulation of complement activation is crucial to avoid self-damage of host cells. The complement cascade is controlled in both the fluid-phase and on host cell surfaces by a class of proteins known as regulators of complement activation (RCAs) [102]. RCAs inhibit the complement cascade at different stages; the cell surface proteins $\mathrm{CD} 46$ and $\mathrm{CR} 1$ and the soluble proteins factor I and factor $\mathrm{H}$ cleave $\mathrm{C}_{3} \mathrm{~b}$ into inactive fragment $\mathrm{iC}_{3} \mathrm{~b}$ [99], while other RCAs such as CD55 and CD59 act up- and downstream, respectively, of $\mathrm{C}_{3} \mathrm{~b}$ in the complement cascade [99]. For an overview of the complement system and RCAs, see Figure 12.

In theory, the host RCAs entail that complement fragments are deposited in different patterns on host vs pathogen surfaces, with $\mathrm{iC}_{3} \mathrm{~b}$ deposition being specific for host. This provides the host immune system with an additional tool to differentiate between self and foreign surfaces. Consequently, the complement system also plays an important role in tolerance, which is illustrated by the fact that loss of function in complement components or their receptors is associated with auto-immune disorders such as SLE [103]. Complement plays an especially important role in the phagocytosis of apoptotic cells, where the presence of $\mathrm{iC}_{3} \mathrm{~b}$ on the apoptotic cell surface mediates efficient uptake by macrophages and dendritic cells without the induction of inflammation or self-immunity [104].

\subsubsection{HIV is opsonized with iC3b in vivo}

Complement is present in blood as well as in seminal and cervical fluid, and all three arms of the complement pathway are activated in the presence of HIV. HIV activates the classical pathway by direct $\mathrm{C} 1$ binding to specific sites in the transmembrane glycoprotein gp41[105] and gp12o[106]. Sugars on gp41 and gp120 also activate the MBL pathway [107].

Most animal and human retroviruses are sensitive to complement mediated lysis [99], [108], but HIV is not [99]. This is due to host RCAs, actively recruited by the virus. During budding from a host cell, HIV selectively incorporates CD46, CD55 and $\mathrm{CD}_{59}$ into its membrane, and also has the ability to bind factor $\mathrm{H}$ to its glycoproteins gp41 and gp120 [109]. This protects HIV from complement mediated lysis, leaving it opsonized in inactivated complement fragments $\mathrm{iC}_{3} \mathrm{~b}$ and $\mathrm{iC}_{3} \mathrm{~d}$ [99]. Figure 13 shows a summary of HIV opsonization. 


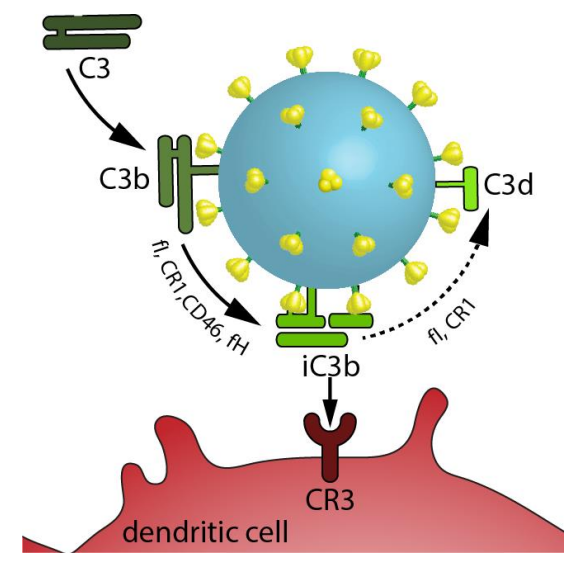

Figure 13. HIV becomes opsonized in iC3b, which can interact with CR3 on dendritic cells. Modified from [110]. $C_{3}$ cleavage can be triggered spontaneously or by interactions between $C_{3}$ and $H I V$ glycoproteins gp12O and gp121. When $C_{3}$ is cleaved into $C_{3} b$ and $C_{3}$ a a thioester bond is exposed that allows $C_{3} b$ to attach to nearby hydroxyl or amino groups to form an ester or amide linkage, respectively. This creates a strong irreversible bond, resulting in the attachment of $\mathrm{C}_{3} b$ on HIV's surface. Under physiological conditions, formation of ester bonds is generally favored, meaning that $\mathrm{C}_{3} b$ has the propensity to bind to carbohydrates, but binding is otherwise nonspecific [111]. Consequently, although certain regions of HIV glycoproteins have been shown to interact with $C_{3} b$ directly [112], $C_{3} b$ deposition can occur on many different sites of the virion. $C_{3} b$ can be processed into inactivated $C_{3} b$ (iC3b) i.e. a complement fragment which no longer can lead to the assembly of $\mathrm{C}_{3}$ convertase and the continuation of the complement cascade. $\mathrm{C}_{3} b$ inactivation is mediated by $\mathrm{fH}$, which has an affinity for binding gp12O, and $\mathrm{CD} 46$, which is selectively incorporated into the virus envelope during budding from the host cell. In settings where fI and CR1 are also present, $i C 3 b$ can be further cleaved into $\mathrm{C}_{3} \mathrm{~d}$.

\subsubsection{HSV2 is opsonized with $\mathrm{C} 3 \mathrm{~b}$ and $\mathrm{iC} 3 \mathrm{~b}$ in vivo}

HSV2 glycoprotein $\mathrm{C}(\mathrm{gC})$ forms a strong noncovalent bond with complement component $\mathrm{C}_{3} \mathrm{~b}$, thereby preventing $\mathrm{C}_{5}$ activation and complement-mediated neutralization [113]. $\mathrm{gC}$ also binds $\mathrm{iC} 3 \mathrm{~b}$ at the same regions as it binds $\mathrm{C}_{3} \mathrm{~b}$ [114]. These complement fragments then remain on the viral surface [115].

\subsubsection{Complement receptors}

The complement receptors $\mathrm{CR}_{3}$ (CD11b/CD18) and CR4 (CD11c/CD18) recognize $\mathrm{iC}_{3} \mathrm{~b}$ [116] in the presence of a bivalent cation [117]. Clusters of $\mathrm{iC}_{3} \mathrm{~b}$, such as the ones that are naturally generated by complement activation, are recognized more efficiently by complement receptors than randomly spaced molecules [118]. CR3 and $\mathrm{CR}_{4}$ bind to different sites on $\mathrm{iC}_{3} \mathrm{~b}$, with $\mathrm{CR}_{3}$ binding to the thioester domain [119].

All myeloid cells, i.e. neutrophil granulocytes, monocytes, macrophages and dendritic cells, express both $\mathrm{CR}_{3}$ and $\mathrm{CR}_{4}$. While both $\mathrm{CR}_{3}$ and $\mathrm{CR}_{4}$ can be found on dendritic cells, $\mathrm{CR}_{3}$ is the dominant receptor in these cells [120, 121]. In 
addition, all NK cells and approximately $10 \%$ of $\mathrm{T}$ cells (mainly CD56+ CD8)

express $\mathrm{CR}_{3}$ [122]. $\mathrm{CR}_{4}$ is expressed on only a subset of NK cells and not expressed on peripheral T lymphocytes, but it appears on both CD4+ and CD8+ CTL clones [122].

$\mathrm{CR}_{3}$ and $\mathrm{CR}_{4}$ bind $\mathrm{iC}_{3} \mathrm{~b}$ selectively, and neither of these receptors bind $\mathrm{C}_{3} \mathrm{~b}$ [123]. $\mathrm{C}_{3} \mathrm{~b}$ can be recognized by CR1 (CD35), but this receptor is not expressed on dendritic cells [124]. CR1 is expressed on monocytes, macrophages, neutrophils, eosinophils, basophils, natural NK cells, B cells and some T cells, as well as follicular dendritic cells, glomerular podocytes, Kupffer cells and erythrocytes [124].

Importantly, our previous studies show that when it comes to dendritic cells, complement fragments on both HIV and HSV2 interact mainly with $\mathrm{CR}_{3}$, as cells from SLE patients with nonfunctional CD11b have similar responses to both free and complement opsonized virus [115, 125]. 


\section{$4 \quad$ Methods}

\subsection{Method overview by paper}

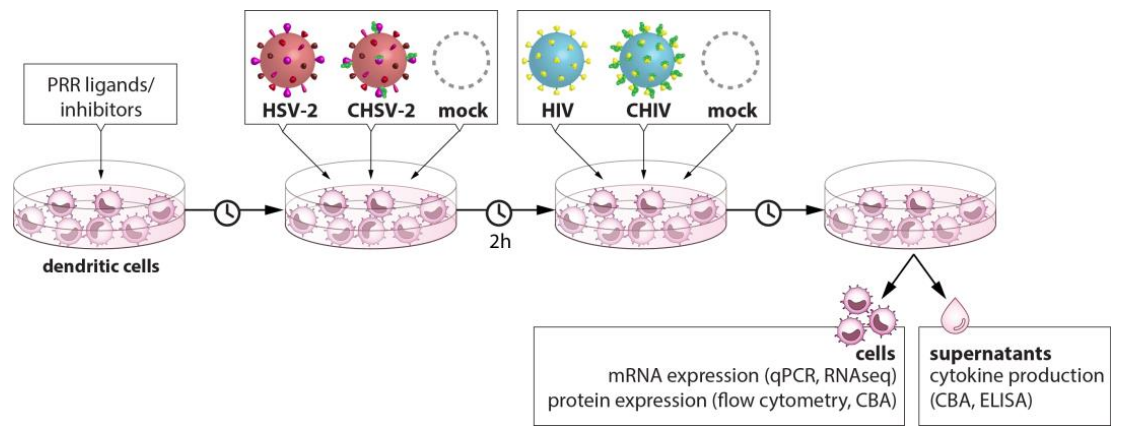

Figure 14. Method overview, Paper I: HSV2 cellular programming enables productive HIV infection in dendritic cells.

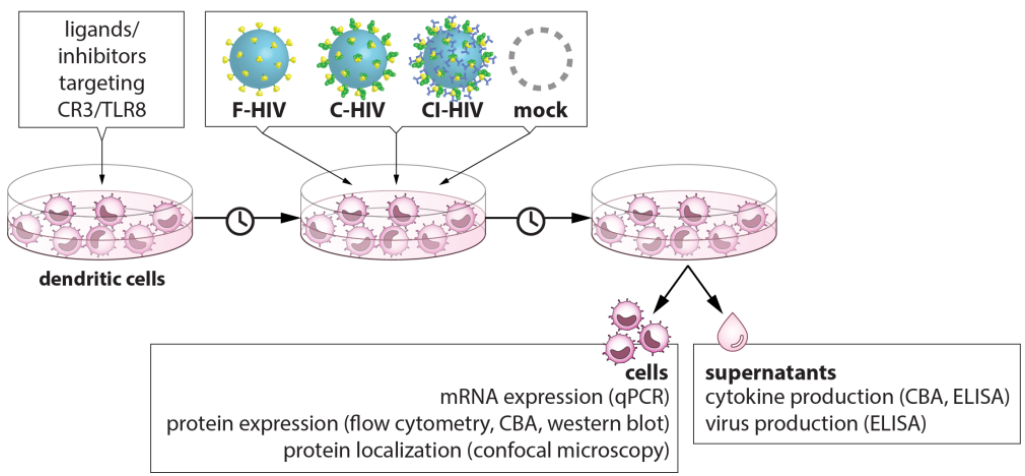

Figure 15. Method overview, Paper II: Complement opsonization of HIV-1 results in decreased antiviral and inflammatory responses in immature dendritic cells via CR3. 


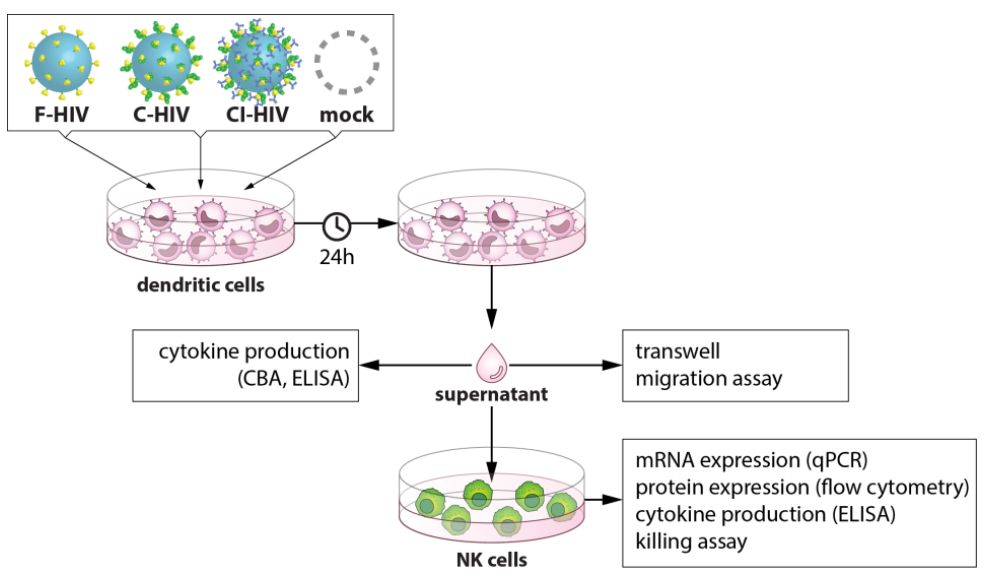

Figure 16. Method overview, Paper III: Impaired NK Cell Activation and Chemotaxis toward Dendritic Cells Exposed to Complement-Opsonized HIV-1.

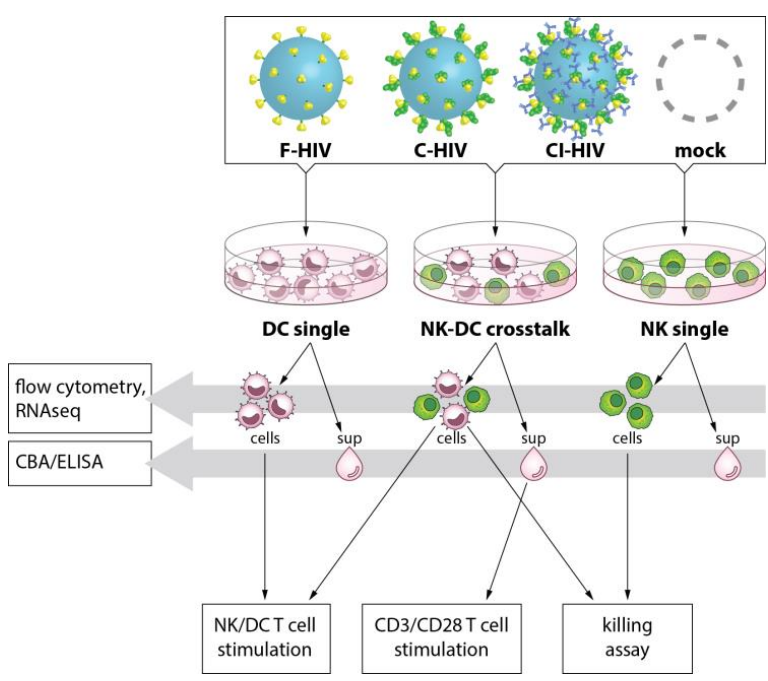

Figure 17. Method overview, Paper IV: Complement Opsonized HIV-1 Alters Crosstalk between Dendritic Cells and NK Cells to Inhibit NK Killing and to Upregulate PD-1, CXCR3 and CCR4 on T Cells 


\subsection{Assays}

\subsubsection{ELISA}

ELISA is an antibody-based technique used to convert the concentration of a factor of interest in a liquid, the analyte antigen, into a color change readout. The components of the assay can be arranged on a surface (plate) in various ways depending on the application and availability of specific antibodies. For an overview of different types of ELISA, see Figure 18.
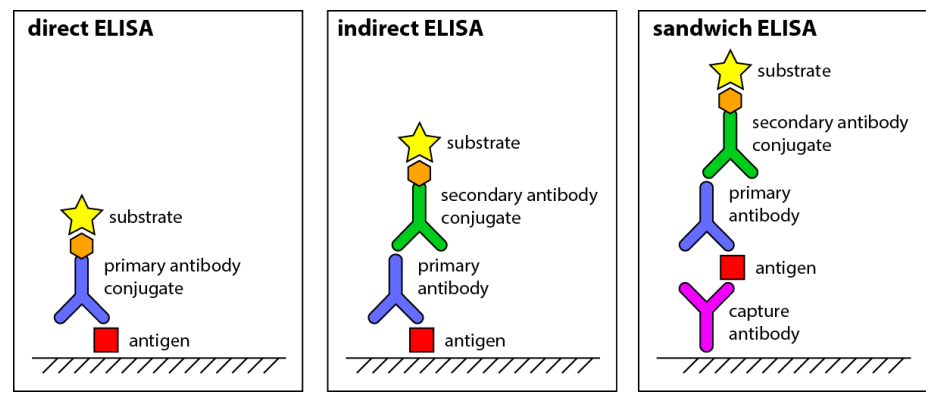

Figure 18. Different forms of ELISA. Antibodies in different constellations bind to the antigen of interest. A conjugate bound to an antibody can react with an added substrate to create a color readout.

\subsubsection{Western blot}

Western blot is a technique to determine the concentration of a specific protein in a lysate sample. The proteins in the sample are denatured and then separated according to size by gel electrophoresis. Specific antibodies are then used to stain the protein of interest. The intensity of the band correlates to the amount of protein in the sample. To facilitate the comparison of protein expression between samples, the intensity of so-called housekeeping proteins, expected to have equal expression in all samples, are used.

\subsubsection{CBA}

Cytometric bead array (CBA) is a flow-cytometry based method to measure concentrations of multiple soluble or intracellular factors within the same sample. It bears an advantage over ELISA due to the low quantity of sample required and the possibility to measure multiple analytes simultaneously. However, the sensitivity of CBA is often lower than ELISA, and commercially available beads exist for fewer factors than commercially available ELISA kits. For an overview of how CBA works, see Figure 19. 

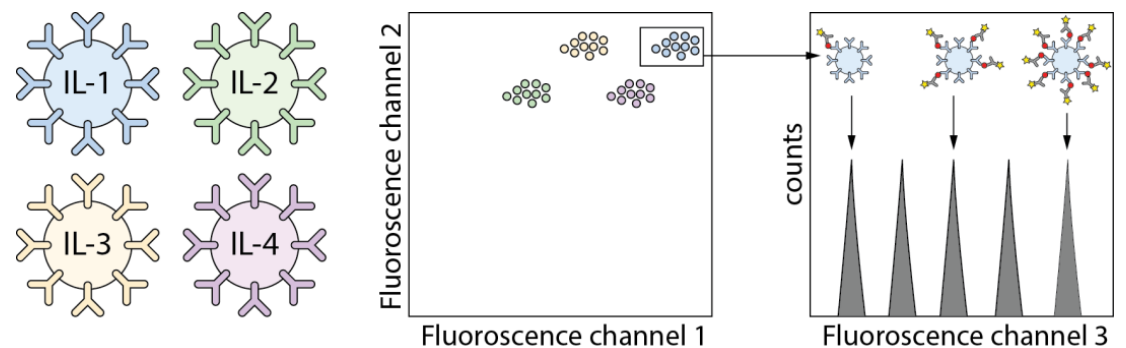

Figure 19. CBA. Beads coated with antibodies specific for different factors are used to detect several substances in a sample simultaneously. Each bead type has a specific fluorescence intensity in two channels, allowing the differentiation of the beads. The amount of analyte that has bound to its corresponding bead type is proportional to the analyte concentration in the sample. Fluorescent conjugates allow the detection of the amount of bound analyte by measuring fluorescent intensity in a third channel.

\subsubsection{Confocal microscopy}

Confocal microscopy is a microscopy technique where a small light beam is focused on the sample one narrow depth level at a time, creating multiple cross sections. This creates a sharp image and makes it possible to determine whether two factors stained with different fluorochromes are located so close together that they can be considered to colocalize. Colocalization can be quantified using computer software. An example of a confocal microscopy image can be seen in Figure 20.

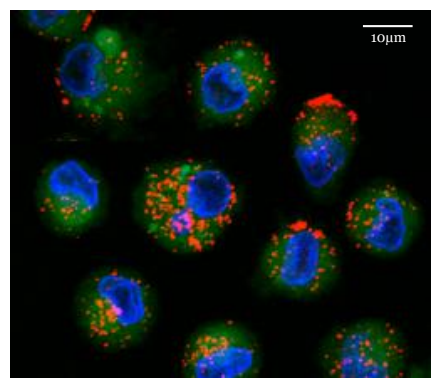

Figure 2o. Example of colocalization assay using confocal microscopy. This image shows dendritic cells exposed to complement opsonized HIV. The cells have been stained with a blue dye that binds to DNA (visualizing the nucleus) and a green dye whose intensity is inversely correlated to $\mathrm{pH}$. HIV is stained red. This setup allows the evaluation of the colocalization of HIV and acidic compartments such as lysosomes.

\subsubsection{Virus generation}

Our research utilizes HIV preparations obtained from the NIH AIDS Research and Reference Reagent Program. These are generated from infected SUPT1 CCR $5 \mathrm{Cl}_{30}$ cells, purified, and concentrated by sucrose gradient ultracentrifugation. This method generates preparations of very high purity. The high purity ensures that our observed results are not affected by the presence of contaminations from the cell cultures that were used during preparation. Such contaminations can for instance 
explain the much higher activation of dendritic cells in response to HIV found by some labs [126]. One possible disadvantage of a preparation with high purity is the lower concentration of microvesicles from the preparations. Microvesicles are "empty" extracellular vesicles often formed simultaneously as HIV virions bud off from host cells, which can impact the effect of the inocula [127]. We have verified that microvesicles do not have an impact on the factors studied in our system by adding varying concentrations of microvesicles to our purified virus preparations (unpublished observation).

Another factor that can affect experimental results is the strain of HIV used. HIV has a remarkable genetic variability, where different clades and subtypes can be associated with differences in virulence, transmission rates, susceptibility to antiviral therapy and disease progression [128]. In our lab, we have assayed the danger responses triggered in dendritic cells exposed to different strains of HIV. We found that all strains tested, including $\mathrm{HIV}_{\mathrm{Bal}}$, HIV $\mathrm{HN}_{\mathrm{MN}}$ and $\mathrm{HIV}_{\mathrm{ADA}}$, as well as several primary isolates all exhibited the same characteristic profile, indicating that the effects we observe in our system are broadly applicable.

In the papers presented in this thesis, we use a HIV concentration of $30 n g / \mathrm{ml}$ p24 equivalent during exposure. This is a relatively high concentration, although it can be observed in vivo during acute infection [129]. The high concentration facilitates a better resolution when studying the pathways and mechanisms that HIV triggers.

\subsubsection{Complement opsonization}

In our lab, the most common method of achieving complement opsonization of HIV or HSV2 is incubation with serum. Blood is drawn from a healthy individual in a vacutainer tube with a red cap (coagulation factor activating), allowed to rest at room temperature for $1 \mathrm{~h}$, centrifuged and then the serum is collected. The collected serum can be used fresh, or frozen for future use. To opsonize, virus is incubated with serum at a $1: 1$ volume ratio for $1 \mathrm{~h}$ at $37^{\circ} \mathrm{C}$. This protocol is a common way of achieving complement opsonization in different systems [130, 131]. Some studies, including previous studies by our lab, have supplemented the serum with additional $\mathrm{Ca} 2+$ and $\mathrm{Mg} 2+$ in the form of veronal buffer [131-133]. We have omitted this supplementation in our later work, as we have not been able to see any benefit in opsonization derived from veronal buffer (unpublished observation).

Our lab has verified that opsonizing in seminal fluid generates similar opsonization to the one obtained when using serum [115, 134]. In addition, incubating HIV with purified $\mathrm{C}_{3}$ protein together with Factor D, Factor B, Ca2+ and $\mathrm{Mg} 2+$ at similar concentrations as found in vivo [102] gave a very similar effect on dendritic cell inflammatory and antiviral responses compared with incubating HIV in serum (unpublished observation).

To prove the dependency of observed results on complement, there are two main approaches: inactivating the activity of complement and manipulating the cells' ability to react to complement by targeting their complement receptors.

There are several ways to inactivate complement described in the literature. Adding EGTA (Ca2+ chelation (Ca2+ chelation), blocks the classical complement pathway only, while EDTA (Ca2+ and Mg2+ chelation) blocks both the classical and alternative pathways [130]. The caveat of these methods is that in our system, the 
opsonizing media is added to the cells together with the virus. A number of cell receptors and activities require the presence of $\mathrm{Ca} 2+$ and $\mathrm{Mg} 2+$, which entails that this method can have unintended and unspecific effects.

Heat inactivation of serum can be used to inactivate complement, although different temperatures and different incubation lengths can give rise to varying results [135]. Several labs report using $\mathrm{C}_{3}$-depleted serum as a control for complement activity $[136,137]$. We have not been able to replicate these results in our HIV system. In our experiments, sera depleted of a factor not required for viral opsonization (C8) did not give the same results as using whole serum. Instead, C8 depleted serum exhibited a similar effect to $\mathrm{C}_{3}$ depleted serum, indicating that the depletion process may have side effects in addition to depleting the target protein (unpublished observation).

The strategies for inhibiting the activity of cell complement receptors include the use of blocking antibodies. These blocking antibodies, however, have been shown to have a modest effect in systems where the involvement of complement receptors has been demonstrated using other methods [130]. siRNA knockdown can be used to eliminate expression of targeted proteins. We have attempted this approach in our lab but found it problematic to study antiviral responses in this system, as the RNA used in siRNA triggered antiviral sensing in our cells (unpublished observation). Genetic modification through CRISPR requires the use of sgRNA which is likely to have a similar effect on antiviral signaling to siRNA. To verify the dependency of observed effects on $\mathrm{CR}_{3}$ in our system, we have successfully used cells from individuals with genetic variants that render this receptor non-functional $[115,138]$.

In addition to blocking complement mediated signaling, we have found it valuable to observe the effects of supplements that activate $\mathrm{CR}_{3}$. $\mathrm{CR}_{3}$ can be activated by ligands binding to different epitopes on the receptor. Activation by some ligands triggers conformational changes and receptor clustering, whereas activation by others does not [139]. When trying to decipher the mechanism behind CR3's ability to suppress inflammatory and antiviral responses, we have found that small $\mathrm{CR}_{3}$ agonists such as NIF, who do not induce receptor clustering, were able to suppress inflammatory but not antiviral responses [138]. In contrast, agonists which cross-link the receptor and induce clustering, such as the monoclonal CD11b antibody KIM75, suppressed both inflammatory and antiviral responses [138]. These results indicate that complement opsonized HIV engages $\mathrm{CR}_{3}$ in manner that leads to receptor clustering.

\subsubsection{Dendritic cell generation}

There are two types of dendritic cells that are relevant to study when it comes to sexual transmission of HIV: Langerhans cells and submucosal myeloid dendritic cells. Studying the function of Langerhans cells is complicated because they are few in number and firmly embedded in the epidermis which entails that they are difficult to isolate and culture without causing functional changes to the cells [140]. Different isolation techniques result in Langerhans cells expressing different sets of TLR receptors, and importantly, isolation techniques that utilize the enzyme trypsin abolish the Langerhans cells' ability to become infected by HIV by cleaving CD4 
[140]. In addition to being problematic to isolate, there is no way of generating cells in vitro that resemble Langerhans cells [140].

In contrast, there is a well-established method to culture cells that resemble submucosal myeloid dendritic cells from CD14+ progenitors (monocytes) isolated from peripheral blood mononuclear cells (PBMCs) [141]. Isolating these cells from PBMCs can be achieved by positive selection of CD14+ cells using CD14 specific antibodies bound to magnetic beads, or by exploiting the propensity of the CD14+ precursors to adhere to plastic surfaces. In our lab, we use the latter method as the use of magnetic beads may affect cell functionality [142] and a very high cell purity can be obtained by allowing the progenitors to adhere to a plastic culture plate and then washing away the non-adherent cells.

Seeing that myeloid dendritic cells, in contrast to Langerhans cells, are found in all types of mucosa where HIV transmission occurs, using a model for this cell type is highly relevant in HIV studies.

ej§§

\subsubsection{NK cell purification and NK mediated killing}

In our studies, we use dendritic cells and NK cells from the same donor when studying the interactions between these cells - both in assays that involve cell-cell contact [143] and when supernatants from dendritic cells are added to the NK cells [144]. PBMCs purified from blood are applied to culture plates and CD14+ dendritic cell progenitors (monocytes) are allowed to adhere. The non-adherent cells are then frozen to allow time for the dendritic cells to develop and to be subjected to appropriate experimental assays. NK cells are purified from the frozen cells the same day that they will be used. NK cells are extracted by negative selection using magnetic bead separation, i.e. all non-NK cells are labeled by antibodies conjugated with magnetic beads to allow their removal. This method allows the NK cells to remain untouched, and typically yields NK cell isolates with 95-98\% purity, as determined by CD56 staining and flow cytometry.

There are two main subsets of NK cells: CD $56^{\mathrm{dim}} \mathrm{CD} 16^{+}$and $\mathrm{CD} 56^{\text {bright }} \mathrm{CD} 16^{+/-}$. The clear majority ( 90\%) of NK cells found in blood are CD56 $6^{\mathrm{dim}} \mathrm{CD} 16^{+}$, while $\mathrm{CD} 56^{\text {bright }} \mathrm{CD} 16^{+/-} \mathrm{NK}$ cells are more common in the secondary lymphoid organs and in tissue. $\mathrm{CD} 56^{\mathrm{dim}} \mathrm{CD} 6^{+} \mathrm{NK}$ cells are considered to be the more cytotoxic subset (i.e. better at killing target cells) whereas $\mathrm{CD} 56^{\text {bright }} \mathrm{CD} 16^{+/-} \mathrm{NK}$ cells are known to rapidly produce cytokines such as IFN $\gamma$, TNF, GM-CSF, and RANTES when they are activated [145]. This makes NK cells isolated from blood a good choice when studying NK-mediated killing. It is important to note, however, that both NK cell subsets can perform both functions - killing and cytokine production - and differ mainly in the threshold and speed for the triggering of the response [146].

In our assays that measure NK killing ability, we use the $\mathrm{K}_{5} 62$ cell line as target cells, which are widely used for this purpose. K562 cells are an erythroleukemia cell line that does not express any detectable MHC class I or class II antigens on its surface. The function of MHC I receptors is to present "self" antigens, i.e. peptides derived from the cell cytosol, and are normally expressed on all cells in the body. $\mathrm{T}$ cells recognize antigens presented MHC class I that are derived from cells that harbor infections or are cancerous, leading to the elimination of these harmful cells. Given that cells that are missing MHC I cannot be detected or destroyed by T cells, 
it is common for pathogens and cancers to downregulate MHC I expression. To combat this immune escape, NK cells kill any cells that lack expression of MHC I [147].

In order to measure the amount of $\mathrm{K}_{5} 62$ cells that become killed by the NK cells, the $\mathrm{K}_{5} 62$ cells were stained using the dye CFSE (5,6-carboxyfluorescein diacetate succinimidyl ester) before they are incubated together with the NK cells. CFSE binds to free amines inside the cells, creating stable fluorescent adducts. The intensity of CFSE staining of a cell declines if the cell undergoes lysis (but not necrosis) [148], and therefore we have used the proportion of $\mathrm{K}_{5} 62 \mathrm{CFSE}^{\text {low }}$ cells as a readout of NK mediated killing.

\subsubsection{T cell stimulation assays and readouts}

As discussed above, the quantity and quality of $\mathrm{T}$ cells that are induced in response to an invading pathogen will have a substantial impact on disease outcome and immunopathology. There are several different commonly used experimental procedures to evaluate $\mathrm{T}$ cell activation.

$\mathrm{T}$ cells respond to peptide antigens presented on MHC molecules through recognition of the $\mathrm{MHC} /$ peptide complex by their $\mathrm{T}$ cell receptor (TCR). While the primary function of $\mathrm{T}$ cells is to react to foreign antigens presented by self-MHC, $\mathrm{T}$ cells respond very robustly to antigenic differences in allogeneic tissues, i.e. to MHC molecules of other individuals [149]. This means that stimulating T cells using dendritic cells derived from a different donor induces MHC-peptide-TCR dependent activation of $\mathrm{T}$ cells that are not specific for the antigen that the dendritic cells are presenting (such as HIV-derived peptides), instead, the T cell is activated by the foreign MHC molecule. We exploit this mechanism to activate $\mathrm{T}$ cells in some of our experiments.

CD3 is a receptor specific to T cells that is used as a marker to identify these cells. It associates with the TCR, forming a complex, and passes on the activating signal into the cell when the TCR is triggered.

In addition to TCR complex activation, a second signal can stimulate T cells further. This signal is mediated by so called co-stimulatory molecules, the most potent of which is CD28. Ligation of CD28 and other co-stimulatory molecules amplifies the activating signaling of the TCR. Normally, the co-stimulatory signal is provided by the dendritic cell presenting the antigen to the $\mathrm{T}$ cell.

$\mathrm{T}$ cell activation can be achieved in vitro by using activating antibodies against CD3 or both $\mathrm{CD}_{3}$ and $\mathrm{CD} 28$. This allows for $\mathrm{T}$ cell activation independently of an antigen presenting cell. In some of our experiments we have used anti-CD3/CD28 beads. This treatment is an even more potent activator of $\mathrm{T}$ cell responses than dendritic cells, as all $\mathrm{T}$ cells are highly activated (as opposed to only those who react to the MHC on the allogeneic cells).

In our experiments, we have used allogeneic dendritic cell stimulation and CD3/CD28 ligation in parallel, as we have found that the two assays have different advantages when it comes to observing the regulation of different immune factors [143].

T cells respond to activation in two main ways: by proliferating and by altering their phenotype. We measure $\mathrm{T}$ cell proliferation using a ${ }^{3} \mathrm{H}$-thymidine assay, which is a common method to measure cell division. The assay involves supplementing the 
cell culture with the radioactive nucleoside $3 \mathrm{H}$-thymidine, which becomes incorporated into new DNA during cell division. The ${ }^{3} \mathrm{H}$ radioactivity in the cell culture can then be measured to determine proliferation.

Different markers, i.e. molecules expressed inside or on the surface of the T cells, are associated with different $\mathrm{T}$ cell responses and/or different susceptibility to HIV infection, as described above.

\subsubsection{Migration assay}

To evaluate which cells were recruited by the dendritic cell after they come into contact with HIV, we have used a transwell migration assay. This assay consists of an upper chamber, separated from a lower chamber by a membrane. This membrane has holes in it that are too small to allow cells to fall through spontaneously, but large enough to allow the cells to squeeze through. The cells that are to migrate, in our case PBMCs, are added to the upper chamber, and the stimulus, in our case supernatants from dendritic cells, are added to the lower chamber, see Figure 21. The cells that migrate to the lower chamber are then collected, quantified and their type determined by flow cytometry.

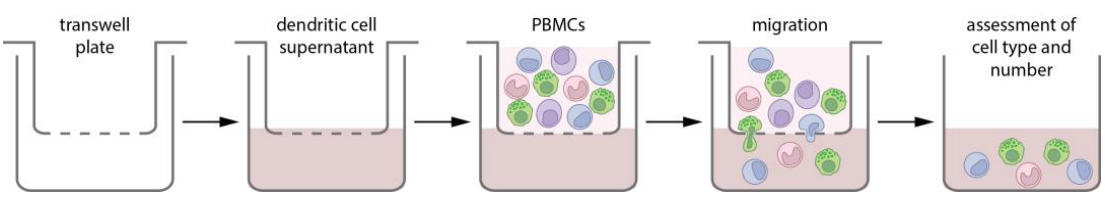

Figure 21. Transwell migration assay. PBMCs (mostly consisting of T cells, monocytes, NK cells and B cells) are allowed to migrate through pores towards dendritic cell supernatants. The number and of type of cell that migrates though the pores is then determined through flow cytometry.

\subsubsection{1 qPCR}

Quantitative polymerase chain reaction (qPCR) is a method to measure the amount of gene expression, i.e. levels of mRNA, for a specific gene. The total RNA in a sample is extracted, purified and converted to DNA. The gene of interest is then amplified using primers specific for part of the gene sequence. The amplification process consists of cycles, where each cycle (theoretically) gives rise to a duplication of the product that the primers are specific for, until the amplification reagents in the assay become limiting. This means that during the exponential amplification, the number of cycles required to reach a certain threshold amount of product copies will be proportional to the number of mRNA molecules in the sample from the beginning.

There are two main ways to track the number of copies in the qPCR reaction after each amplification cycle: fluorescent dyes, such as SYBR green, that intercalate with any double-stranded DNA, and sequence-specific oligonucleotide DNA probes (such as TaqMan) which fluoresce only after hybridization of the probe with its complementary sequence. While sequence specific probes are more precise and allow the detection of genes with a very low expression, fluorescent dyes are easier and cheaper to use. In our lab, we use SYBR green. 
To facilitate comparison of gene expression levels between different samples, the expression of the gene of interest is compared to the expression of so-called housekeeping genes. Housekeeping genes are genes that are constitutionally expressed i.e. not easily affected by different treatments or stimuli. Calculating the relative amount of expression of a gene of interest compared to the expression of housekeeping genes therefore allows for comparison of expression between different samples. In our lab, we use glyceraldehyde 3-phosphate dehydrogenase (GAPDH) and $\beta$-actin as housekeeping genes.

\subsubsection{RNAseq}

RNAseq is a next generation sequencing-based method to measure the expression of all genes in a sample, i.e. the transcriptome. The measurement of each gene is not as exact as the measurement achieved using qPCR, but the measurement of the entire transcriptome simultaneously gives a very detailed view of all the pathways and processes that are active at a given time. Also, RNAseq allows for a more exploratory approach, where the genes of interest are not defined in advance.

Like qPCR, the RNAseq process begins with the purification of RNA from a sample, and its conversion to cDNA. Most RNA molecules present in a cell are ribosomal RNA (i.e. not of interest). The proportion of mRNA derived material in the sample can be increased either using ribosomal RNA-specific probes conjugated to magnetic beads to remove the ribosomal RNA or by positive selection of mRNA using oligo(dT) primers which are specific for the poly(A) tails of the mRNA-derived sequences. One possible drawback of using poly(A) selection instead of specific depletion of ribosomal RNA is that poly(A) selection omits small non-coding regulatory RNAs (microRNAs) from the analysis. Most commercial kits for RNA sample preparation, however (including the ones used by us) use poly(A) selection. Once the mRNA has been amplified, each sample is ligated to a specific adaptor index, which is a sequence used to identify which sample a mRNA molecule belongs to when several samples are sequenced together.

The amplified cDNA from a sample ligated to adaptors is called a library. Several libraries are pooled together and sequenced. The reads derived from each DNA molecule in the sample will consist of a sequence of bases, coupled to a quality score coupled to each position, i.e. a measure of how "certain" the sequencing machine is that it has read the correct signal for that particular base.

The reads and their quality scores are usually saved in fastq file format. These files contain a lot of information, in our case over $3 \mathrm{~GB} /$ sample. Converting this information into a gene expression profile and performing statistics to determine how expression profiles between different groups of samples differ requires many different bioinformatics algorithms and tools. The first step is to remove sequences that are of bad quality. The reads are then mapped to the human genome, to see which gene they originate from. The number of reads that originate from a gene are proportional to its expression in the sample. To normalize samples to be able to make comparisons between them, the usual strategy is to assume that the expression of the vast majority of genes will not differ, i.e. to normalize to the total amount of gene counts in each sample. Statistics can then be performed using various algorithms. An overview of our RNAseq analysis pipeline can be found in Figure 22. 


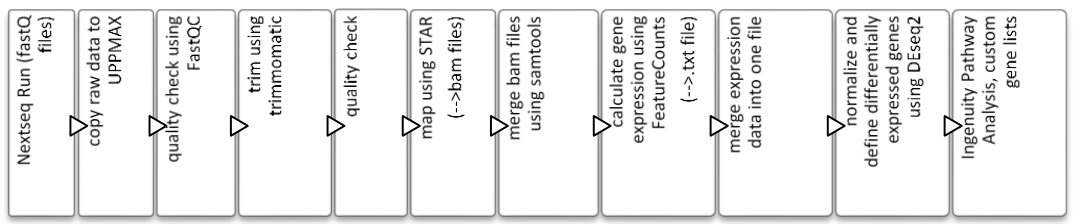

Figure 22. RNAseq analysis pipeline. Files are downloaded from the sequencing machine (NextSeq) and uploaded to Uppsala Multidisciplinary Center for Advanced Computational Science (UPPMAX), a computing resource provided through Uppsala University. There, the data quality is checked and adapters and low-quality reads are removed. The resulting sequences are mapped to the human genome to determine the number of reads that originate from each gene.

The data is then downloaded back to a regular computer where statistics and comparisons between samples can be performed using $R$. The resulting data is a complete comparison of the transcriptome between different conditions. This can be filtered using custom gene lists, or analyzed using pathway analysis software such as Ingenuity (Qiagen), which utilizes databases to find patterns of gene regulation that are associated with previously published responses and signaling pathways.

\subsubsection{Flow cytometry}

Flow cytometry is a method of analyzing single cell protein expression by passing cells through a detector in single file. Typically, the cellular proteins of interest are labelled using fluorochrome-conjugated antibodies, which are excited by lasers with different wavelengths and the light emitted by the fluorochromes are detected (see Figure 23). In addition, the size and granularity of the cells can be assayed by measuring how much light is scattered forwards and sideways, respectively.

The number of factors that can be measured at the same time on the same cell are typically limited by the number and types of fluorochromes that can be detected by the cytometer without overlap in the signal. The flow cytometer used in most of our studies can detect 8 different colors simultaneously.

Once the data is collected. groups of cells are gated (selected) in an analysis program based on their size, granularity and marker expression. Usually in experiments, one color is reserved for staining for dead/apoptotic cells, as these cells tend to bind antibodies non-specifically. For a description of gating strategy, see Figure 24. 


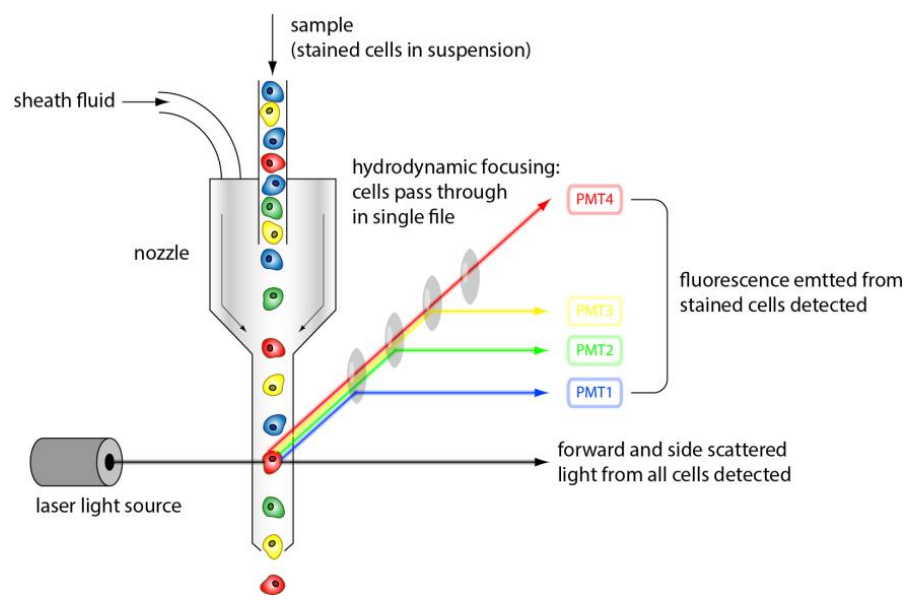

Figure 23. Flow cytometry. Cells stained with various fluorochromes are passed through a detector in single file, excited by lasers with different wavelengths and the emitted light from each cell is registered. The scattering of light forwards (FSC) and sideways (SSC) is also registered.
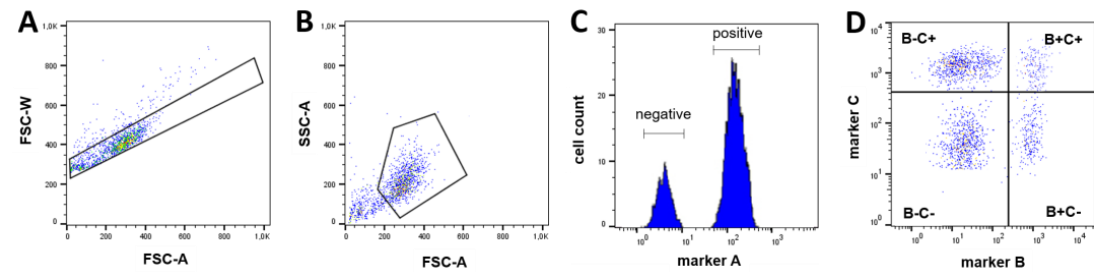

Figure 24. Flow cytometry gating. (A) All events recorded by the flow cytometer as peaks, with different properties: the height $(H)$ of the peak, the area $(A)$ underneath the peak and the width $(W)$ of the peak. For single cells passing through the detector, FSC-W should correlate with FSC-A, appearing as a diagonal when these variables are plotted in a scatter plot. Cells that have aggregated together (so-called doublets) will appear outside this diagonal and can be removed from subsequent analysis. (B) Different cell types have different size (FSC) and granularity (SSC), so plotting these factors can be used to select a certain type. In addition, this plot is useful for excluding debris (typically with very low FSC and SSC) from the analysis. Cell populations can be gated either based on their expression of one $(\boldsymbol{C})$ or several factors (D). Positive and negative controls are used to determine the locations of positive and negative populations, respectively. 


\section{Results and Discussion}

\subsection{Results overview}

Table 3. Results overview, paper II-IV.

\begin{tabular}{|c|c|c|c|}
\hline & $\begin{array}{l}\text { paper: } \\
\text { figure }\end{array}$ & factor measured & method; material; timepoint \\
\hline \multicolumn{4}{|l|}{ dendritic cells exposed to HIV... } \\
\hline \multirow{7}{*}{$\begin{array}{l}\text {...activate inflammatory } \\
\text { responses and } \\
\text { cytokines }\end{array}$} & II:F1,T1,T2 & IL1b, IL6, TNFa, CCL3 mRNA & qPCR; DC cell lysate; $6-48 \mathrm{~h}$ \\
\hline & 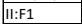 & IL1b, IL6, IL12, TNFa, CXCL8 protein & CBA; DC sup; 24h \\
\hline & \begin{tabular}{|l|l|} 
IV:F1 \\
\end{tabular} & IL15, IL5, CXCL8 protein & CBA; DC sup; $24 \mathrm{~h}$ \\
\hline & II:T2 & CCL5, CCL17, EB13, TRAF1, TNFAIP2 protein & mass spectrometry; DC cell lysate; $24 \mathrm{~h}$ \\
\hline & IIII:F1 & CCL3, CCL13, CCL17, CCL18, CCL22 and CXCL8 protein & CBA/ELISA; DC sup; 6-24h \\
\hline & IV:F2 & IL19, IL12A, IL32, IL15, IL1b mRNA (in presence of NK) & RNAseq; DC cell lysate; $24 \mathrm{~h}$ \\
\hline & IV:F2,TS1 & $\begin{array}{l}\text { Activation of TNF, IL1b, IL1a, TLR7, RELA, IL13 upstream } \\
\text { regulators (in presence of NK) }\end{array}$ & RNAseq/IPA; DC cell lysate; $24 \mathrm{~h}$ \\
\hline \multirow{8}{*}{$\begin{array}{l}\text {...activate antiviral } \\
\text { responses }\end{array}$} & II:F2,T1,T2 & IFNb mRNA & qPCR; DC cell lysate; $1-3 \mathrm{~h}$ \\
\hline & II:F2,T1,T2 & IFIT3, APOBEC3A, Tetherin mRNA & qPCR; DC cell lysate; 6-24h \\
\hline & II:F2,T1,T2 & MXA, MX2, GBP1, GBP2, IFIT1, IFIT3, IFIH1, ISG15 protein & mass spectrometry; DC cell lysate; $24 \mathrm{~h}$ \\
\hline & II:F2,T1,T2 & IFNb protein & ELISA; DC sup; $3 \mathrm{~h}$ \\
\hline & II:F2,T1,T2 & MXA mRNA & qPCR; DC cell lysate; $6-12 \mathrm{~h}$ \\
\hline & II:F2,T1,T2 & MXA protein & western blot; DC cell lysate; $12 \mathrm{~h}$ \\
\hline & IV:F2,TS1 & Activation of IFNg upstream regulator (in presence of NK) & RNAseq/IPA; DC cell lysate; $24 \mathrm{~h}$ \\
\hline & IV:F4 & IFNg protein secretion (in presence of NK) & $\mathrm{CBA} ; \mathrm{DC} / \mathrm{NK}$ sup; $24 \mathrm{~h}$ \\
\hline ...activate MyD88 & II:T1 & MyD88 mRNA & qPCR; DC cell lysate; $48 \mathrm{~h}$ \\
\hline ...activate $\mathrm{p} 38, \mathrm{PI} 3 \mathrm{k}$ and ERK & II:F4 & phospho-p38, phospho-PI3k, phospho-ERK protein & western blot; DC cell lysate; $12 \mathrm{~h}$ \\
\hline ...activate JNK and Akt & IV:F2 & JNK and Akt upstream regulators & RNAseq/IPA; DC cell lysate; $24 \mathrm{~h}$ \\
\hline \multirow{3}{*}{...activate IRF1 and IRF7 } & II:F3 & IRF1, IRF3, IRF7 mRNA & qPCR; DC cell lysate; $3-6 \mathrm{~h}$ \\
\hline & II:F3 & IRF1, IRF3, IRF7 protein & western blot; $\mathrm{DC}$ cell lysate; $6-12 \mathrm{~h}$ \\
\hline & II:F3 & IRF1 protein translocation to nucleus & confocal microscopy; DC cells; $6-12 \mathrm{~h}$ \\
\hline \multirow{5}{*}{....activate NFkB } & II:F4 & NFkB mRNA & qPCR; DC cell lysate; 6-12h \\
\hline & II:F4 & NFkB protein & western blot; DC cell lysate; $12 \mathrm{~h}$ \\
\hline & II:F4 & NFkB protein & mass spectrometry; DC cell lysate; $24 \mathrm{~h}$ \\
\hline & II:F4 & NFkB protein translocation to nucleus & confocal microscopy; DC cells; $12 \mathrm{~h}$ \\
\hline & IV:F1 & Activation of NFkB upstream regulator & RNAseq/IPA ; DC cell lysate; $24 \mathrm{~h}$ \\
\hline \multirow{2}{*}{...mature (in presence of NK) } & IV:F2 & PDL1, CD80, CD86, CD40, OX40L protein (in presence of NK) & flow cytometry; DC cells; $24 \mathrm{~h}$ \\
\hline & IV:F2 & CD80, CD86, CD83, CD40 mRNA (in presence of NK) & RNAseq; DC cell lysate; $24 \mathrm{~h}$ \\
\hline $\begin{array}{l}\text {...recruit NK cells, monocytes, B cells, CD4 T } \\
\text { cells and CD8 T cells }\end{array}$ & III:F2 & $\begin{array}{l}\text { number of NK cells, monocytes, B cells, CD4 T cells and CD8 T } \\
\text { cells crossing transwell }\end{array}$ & $\begin{array}{l}\text { transwell + flow cytometry; PBMCs } \\
\text { exposed to DC sup; 90min (24h) }\end{array}$ \\
\hline \multirow{3}{*}{...activate NK cells } & III:F3 & CD25, CD69, CCR7, HLADR and TIM3 on NK cell surface & $\begin{array}{l}\text { flow cytometry; NK cells (exposed to } \\
\text { DC sup); } 24 \mathrm{~h}(24 \mathrm{~h})\end{array}$ \\
\hline & III:F4 & IFNg, IL2, IL10, IL15 mRNA & $\begin{array}{l}\text { qPCR; NK cell lysates (NK exposed to } \\
\text { DC sup); 6-24h (24h) }\end{array}$ \\
\hline & III:F4 & IFNg protein & $\begin{array}{l}\text { ELISA; NK sups (NK exposed to DC sup); } \\
24 \mathrm{~h}(24 \mathrm{~h})\end{array}$ \\
\hline \multirow{2}{*}{....induce NK cell killing } & III:F5 & perforin and granzyme B mRNA & $\begin{array}{l}\text { qPCR; NK cell lysates (NK exposed to } \\
\text { DC sup); } 24 h(24 h)\end{array}$ \\
\hline & III:F5 & killing of target cells (K562) by NK & $\begin{array}{l}\text { flow cytometry; K562 killed by NK } \\
\text { (exposed to DC sup); } 6 \mathrm{~h}(24 \mathrm{~h})\end{array}$ \\
\hline \multicolumn{4}{|c|}{ the HIV-induced inflammatory and antiviral responses... } \\
\hline ...are not dependent on viral fusion & 11:FS3 & IL1b and MXA mRNA induced by HIV \pm b12 or in cells \pm C 34 & qPCR; DC cell lysate; $6 \mathrm{~h}$ \\
\hline ....are dependent on endosomal acidification & II:F5 & IL1b and MXA mRNA in cells $\pm 30 \mathrm{nM} \mathrm{NH4Cl}$ & qPCR; DC cell lysate; $6 \mathrm{~h}$ \\
\hline ...are dependent on TLR8 & II:F5 & IL1b and MXA mRNA in cells \pm IRS957 & qPCR; DC cell lysate; $6 \mathrm{~h}$ \\
\hline ...are dependent on $\mathrm{p} 38$ and ERK signaling & II:F7 & IL1b and MXA mRNA in cells $\pm p 38$ and ERK inhibitors & qPCR; DC cell lysate; $6 \mathrm{~h}$ \\
\hline ....are dependent on PI3k (antiviral only) & II:F7 & IL1b and MXA mRNA in cells \pm PI3k inhibitor & qPCR; DC cell lysate; $6 \mathrm{~h}$ \\
\hline \multicolumn{4}{|l|}{ complement opsonization of HIV... } \\
\hline \multirow{2}{*}{...increases infection } & II:F2 & early gag transcript & qPCR; DC cell lysate; $3-48 \mathrm{~h}$ \\
\hline & II:F2 & p24 & ELISA; DC sup; 3-10d \\
\hline \multirow{3}{*}{...activates IRF3 signaling } & II:F3 & IRF3 mRNA & qPCR; DC cell lysate; 3-6h \\
\hline & II:F3 & IRF3 protein & western blot; DC cell lysate; $6-12 \mathrm{~h}$ \\
\hline & II:F3 & IRF3 protein translocation to nucleus & confocal microscopy; DC cells; 6-12h \\
\hline ...activates Lyn & II:F4 & phospho-Lyn protein & western blot; DC cell lysate; $12 \mathrm{~h}$ \\
\hline $\begin{array}{l}\text {...activates upstream regulators associated } \\
\text { with growth, survival and transcription }\end{array}$ & IV:F2 & activation of upstream activators (mRNA) (in presence of NK) & RNAseq/IPA; DC cell lysate; $24 \mathrm{~h}$ \\
\hline \multicolumn{4}{|c|}{ complement-mediated supression of inflammatory and antiviral responses and increase of infection... } \\
\hline ...can be achieved by CR3 activation & II:F6 & IL1b, TNFa, MXA and gag mRNA \pm activating CD11b antibody & qPCR; DC cell lysate; $6 \mathrm{~h}$ \\
\hline ...is dependant on CR3 & 11:F6 & $\begin{array}{l}\text { IL1b, TNFa, MXA and gag mRNA in cells with non-functional } \\
\text { CD11b }\end{array}$ & qPCR; DC cell lysate; $6 \mathrm{~h}$ \\
\hline
\end{tabular}




\begin{tabular}{|c|c|c|c|}
\hline \multicolumn{4}{|l|}{ NK cells... } \\
\hline ...migrate in response to CCL3 and CXCL10 & III: $\mathrm{F3}$ & $\begin{array}{l}\text { Number of NK (of PBMCs) that migrate towards DC } \\
\text { supernatants in transwell assay } \pm \text { CCL3 or CXCL10 blocking } \\
\text { abs }\end{array}$ & $\begin{array}{l}\text { flow cytometry; PBMCs (exposed to DC } \\
\text { sup); } 90 \mathrm{~min} \text { (24h) }\end{array}$ \\
\hline $\begin{array}{l}\text {...upregulate IFN-driven upstream regulators } \\
\text { when stimulated by DCs }\end{array}$ & $111: F 3$ & upstream regulator activation based on mRNA expression & RNAseq/IPA; NK cell lysate; $24 \mathrm{~h}$ \\
\hline $\begin{array}{l}\text {...upregulate activation markers in response } \\
\text { to HIV (in precence of DCs) }\end{array}$ & IV:F3 & HLADR, CD69, PD1, CCR7 protein & flow cytometry; NK cells; $24 \mathrm{~h}$ \\
\hline $\begin{array}{l}\text {...upregulate killing ability in response to } \\
\text { supernatants from dendritic cells exposed to } \\
\text { HIV }\end{array}$ & III:F5 & perforin and granzyme expression, killing of $\mathrm{K} 562$ cells & $\begin{array}{l}\text { flow cytometry; NK cells; K562 cells; } \\
24 \mathrm{~h}(6 \mathrm{~h})\end{array}$ \\
\hline $\begin{array}{l}\text {...upregulate killing ability in response to } \\
\text { contact with dendritic cells }\end{array}$ & IV:F5 & killing of $\mathrm{K} 562$ cells & $\begin{array}{l}\text { flow cytometry; NK cells; K562 cells; } \\
24 \mathrm{~h} \text { (6h) }\end{array}$ \\
\hline \multicolumn{4}{|c|}{ T cells primed by HIV-exposed denritic cells... } \\
\hline ...proliferate less & IV:F6 & cell division & thymidine assay; $T$ cell lysate; $d 5$ \\
\hline ...obtain central memory phenotype & IV:F6 & size of CD45RA-CCR7+ population & flow cytometry; $\mathrm{T}$ cells; $\mathrm{d} 4$ \\
\hline ...are cytotoxic (CD8) & IV:F6 & perforin protein exptression in CD8 T cells & flow cytometry; $\mathrm{T}$ cells; $\mathrm{d} 4$ \\
\hline \multicolumn{4}{|c|}{ T cells primed by C-HIV-exposed dendritic cells... } \\
\hline $\begin{array}{l}\text {...upregulate CXCR3 and CXCR4 (especially } \\
\text { CD4 T cells) in presence of NK cells }\end{array}$ & IV:F7 & size of $\mathrm{CXCR3}+, \mathrm{CCR} 4+, \mathrm{CXCR} 3+\mathrm{CCR} 4+$ populations & flow cytometry; $\mathrm{T}$ cells; $\mathrm{d} 4$ \\
\hline ...upregulate CD38 & IV:F8,9 & size of $C D 38+$ population & flow cytometry; $\mathrm{T}$ cells; $\mathrm{d} 4$ \\
\hline $\begin{array}{l}\text {...coexpress negative immune checkpoints } \\
\text { PD1, TIM3 and LAG3 }\end{array}$ & IV:F8,9 & size of PD1+LAG3+TIM3+ population & flow cytometry; $\mathrm{T}$ cells; $\mathrm{d} 4$ \\
\hline
\end{tabular}

Factors upregulated when HIV is complement opsonized marked in green. Factors downregulated when HIV is complement opsonized marked in red. DC=dendritic cell, sup = supernatant, $C$-HIV=complement opsonized HIV.

\subsection{HIV and TLR8 signaling}

\subsubsection{HIV triggers weak danger responses in dendritic cells}

In our studies, we frequently refer to the fact that complement suppresses HIVderived danger signaling. It is important to note, however, that HIV has a number of mechanisms in addition to the use of complement to avoid triggering inflammatory and antiviral responses - dendritic cells generally do not react strongly to HIV [71, 150]. Consequently, complement opsonization of HIV lowers danger signaling from an already low level. That being said, studies show a negative correlation between dendritic cell danger signaling and HIV susceptibility [62]. The exact pathways triggered in the dendritic cells by the virus will likely have a profound impact on the outcome of HIV exposure and shape the adaptive immune response.

\subsubsection{HIV triggers TLR8}

We have found that HIV engages TLR8 in dendritic cells, activates NFk $\beta$, IRF1 and IRF7, and leads to the mounting of danger signaling resulting in the upregulation of antiviral and inflammatory factors, which is in accordance with studies by others $[68,71,151-153]$. The dependency of the observed responses on TLR8 is supported by the fact that the responses were abrogated when TLR8 signaling was blocked, either by suppressing endosomal acidification or by using a specific inhibitor oligonucleotide. In addition, an upregulation of gene expression of MyD88, a signal transducer directly downstream of TLR8, was observed.

\subsubsection{What happens downstream of TLR8}

Downstream of TLR8, we have detected the activation of ERK, JNK and p38 MAPK. ERK and p38 MAPK are critical for both pro- and anti-inflammatory immune 
responses in dendritic cells [154]. In addition, ERK, JNK and p38 MAPK are required for dendritic cell maturation: either directly or via interferon signaling depending on the exact setting [155]. We found that STAT1, an interferon-inducible transcription factor shown to be important for dendritic cell maturation, is activated in our system [156].

We also observed an activation of PI3k and AKT. Interestingly, antiviral, but not inflammatory responses were suppressed when we blocked PI3k, indicating that these two responses may be triggered by somewhat diverging pathways.

$\mathrm{NFk} \beta$ activation was detected as a response to HIV, as well as the activation of IRF1 and IRF7. These transcription factors could act as transcription factors for the expression of early gag transcript in dendritic cells exposed to free HIV. In addition to mediating danger signaling by acting as a transcription factor for inflammatory and antiviral genes, $N F k \beta$ has also been shown to modulate other signaling events in dendritic cells. As mentioned above, the activation of ERK, JNK and p38 MAPK can lead to both inflammatory and anti-inflammatory signaling. The presence of $\mathrm{NFk} \beta$ together with $\mathrm{p} 38 \mathrm{MAPK}$ activation is associated with robust inflammatory reactions [157], whereas the if $\mathrm{PI}_{3} \mathrm{~K} / \mathrm{AKT}$ and ERK signaling are more dominant the inflammatory response is dampened [157].

A recent study showed that NFk $\beta$ transcription activity is cross-regulated in a way that favors IRF1 and IRF7 but inhibits IRF3 [158]. If this mechanism is active in our system, it would entail that AP-1 is active as well [158]. We have not specifically assayed AP- 1 activation, but the produced inflammatory factors and cytokines we have observed fit well with its activity.

Another possible source of IRF7 activation is an interferon-driven positive feedback [159]. This hypothesis is supported by the observation that IRF7 upregulation is observed at a later timepoint, $6 \mathrm{~h}$, compared to the upregulation of IRF1 and interferon which peak $3 \mathrm{~h}$ post virus exposure.

In summary, we suggest that $\mathrm{NFk} \beta$ together with p38 MAPK likely are the dominant drivers behind the danger responses triggered by HIV-induced TLR8 activation. The danger signaling also involves ERK, PI3k and AKT, and is associated with the activation of IRF1 and IRF7, and probably AP-1. ERK, JNK and p38 MAPK, together with STAT1, are required for dendritic cell maturation.

\subsubsection{Kinetics of danger responses to HIV}

The danger responses triggered by HIV in dendritic cells began with an early, transient interferon response $3 \mathrm{~h}$ post exposure. At $6 \mathrm{~h}$ post exposure, nuclear translocation of $\mathrm{NFk} \beta$ and IRF1 could be observed. This was associated with an increase in expression of antiviral factors such as MX1, IFIT3 and APOBEC 3 A, peaking at 6-24h post exposure. Several inflammatory cytokines, including IL-1 $\beta$, IL-6, TNF, CXCL10 and CCL3 also peaked at 6-24h post virus exposure.

Studies concerning the kinetics of danger signaling in dendritic cells describe that antiviral and inflammatory signaling occur in several different waves, which is in accordance with our observations $[152,160]$. A recent interesting publication by Decalf et al using monocyte derived macrophages described two waves of antiviral responses triggered by HIV [152]. An early wave was detectable $6 \mathrm{~h}$ post exposure, peaked $24 \mathrm{~h}$ post exposure, and was not dependent on HIV reverse transcription. This wave was found to be initiated by an induction of low levels of interferon [152]. 
The authors refer to unpublished results indicating that this response was not observed when using monocyte derived dendritic cells instead of macrophages. We, however, have observed a similar early antiviral response in monocyte derived dendritic cells in our system that lead to subsequent activation of ISGs such as MX1 [125]. The interferon response that we observed peaked at $3 \mathrm{~h}$ post exposure and was very transient - it was no longer detectable at $6 \mathrm{~h}$ post exposure [125]. The early timepoint of this response, in combination with the short time frame when it could be measured could offer an explanation to why Decalf et al failed to make a corresponding observation in their monocyte derived dendritic cells.

\subsection{HIV and complement signaling}

\subsubsection{Complement opsonized HIV interacts with CR3}

Complement opsonization of HIV has multiple effects on dendritic cells including increased viral uptake, higher infection, and more efficient trans-infection of $\mathrm{T}$ cells $[132,161]$. Importantly, the enhanced infection is not only a result of more viral uptake; as seen in experiments where infection of dendritic cells is initiated by and equal amount of free and complement opsonized virions (unpublished observation).

In our studies, we have found that the effect of complement opsonization of HIV on dendritic cells appears to be mediated exclusively by CR3.

\subsubsection{TLR-CR crosstalk}

Bidirectional crosstalk between TLRs and CRs can have profound effects on the shaping of early innate immune responses in vivo [162]. Early systematic studies showed that the presence of complement activation can amplify inflammatory signals triggered through TLRs [163]. These studies showed that TLR and CR signaling converged at the activation of ERK and JNK, which activated NFK $\beta$ and AP-1 [163]. Later studies have described that while CR3 ligation can augment TLR signaling via TLR2 and TLR4 by facilitating the recruitment of the adapter MyD88 in some settings [164], in other settings CR3 stimulation appears to dampen TLR signaling by degrading MyD88 and TRIF instead [165].

Importantly, TLR7/8 mediated inflammation has been shown to be inhibited by CD11b ligation [166]. This inhibition is exploited by some pathogens, in order to be taken up without killing despite simultaneous danger signaling via TLRs [167] as the phagosomes formed do not readily fuse with lysosomes [168]. We have observed this phenomenon in our system - complement opsonized HIV taken up by dendritic cells localized in less acidic compartments than free HIV [169]. This uptake mechanism is believed to be the same as is triggered by apoptotic cells covered in $\mathrm{iC}_{3} \mathrm{~b}$, where the apoptotic cells are cleared while avoiding the triggering of inflammatory responses $[170,171]$. The role of $\mathrm{iC} 3 \mathrm{~b}$ as a suppressor of immune activation of dendritic cells has also been demonstrated in systems investigating the development of peripheral tolerance [171] and inability to mount adequate immune responses towards tumors [172].

The exact mechanism CR3 utilizes to suppress TLR mediated danger signaling remains to be elucidated. $\mathrm{CR}_{3}$ ligation has been shown to activate Lyn by multiple studies, including by our group [172]. Lyn in turn can activate PI3k and AKT in a 
manner which promotes cell survival, which is one possible signaling event responsible for the increased expression of factors associated with growth and survival observed when dendritic cells are exposed to complement opsonized HIV. Roberts et al found that PI3k activated by $\mathrm{CR}_{3}$ ligation led to the upregulation of MKP-1, which can inhibit p38 MAPK and thereby suppress the inflammatory response [173]. Soukup et al described that a similar effect was mediated by MK2, which could inhibit TLR-mediated inflammatory responses triggered by LPS [154]. None of these factors appear to be significantly affected in our transcriptomic studies, but their involvement cannot be excluded as upregulation of these factors is transient. Soukup et al measured MK2 expression at $6 \mathrm{~h}, 12 \mathrm{~h}, 24 \mathrm{~h}$ and $48 \mathrm{~h}$, but could only detect upregulation at 24h [154].

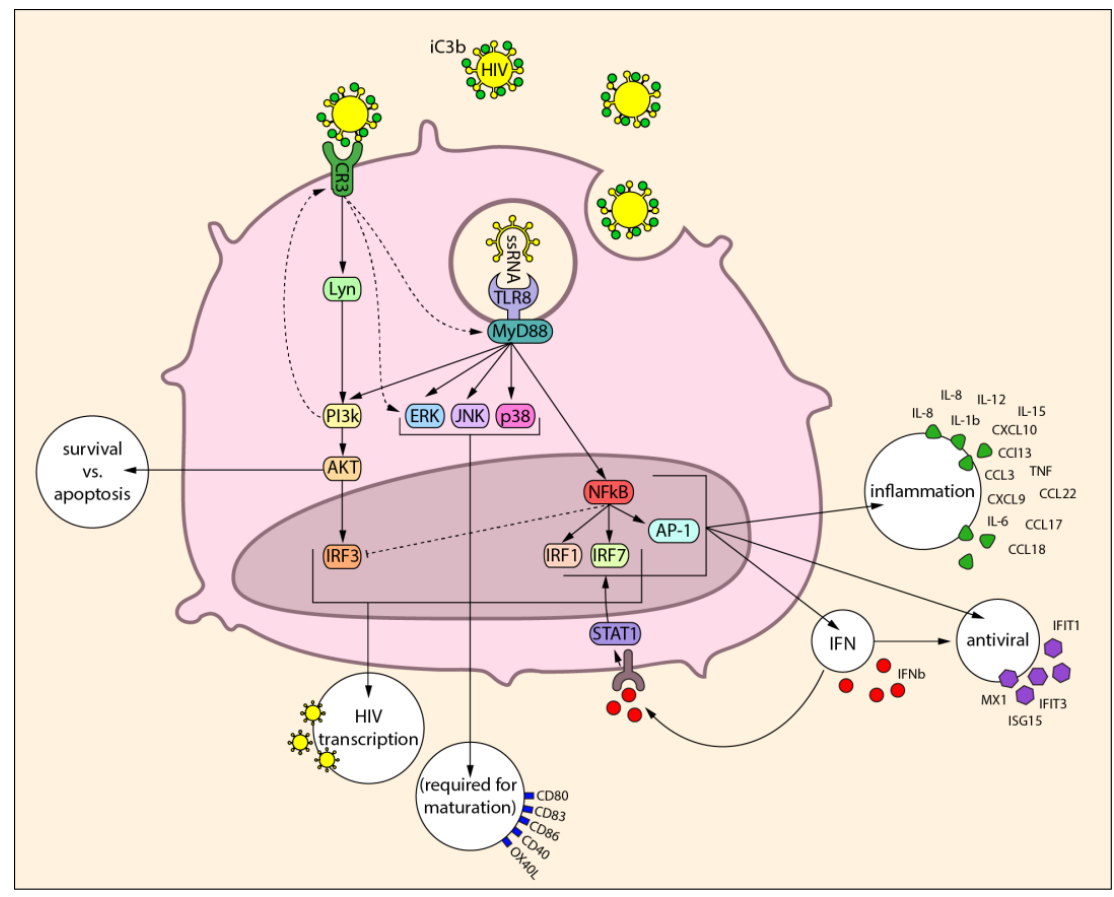

Figure 25. Pathways involved in dendritic cell responses to complement opsonized HIV. HIV-derived ssRNA triggers TLR8, leading to the activation of ERK, JNK, p38 and NFk $\beta$. $i C_{3} b$ bound to the viral surface activates $C_{3}$, leading to a $C R / T L R$ crosstalk and the activation of Lyn, which results in stimulation of the PI3k/AKT axis. This causes the balance to shift from p38 and NFk $\beta$ dominance, which would lead to immune activation, to setting where PI3k and ERK direct the response to suppress inflammation and enhance survival. IRF3 resulting from $P I_{3} k$ activation can act as a transcription factor for HIV replication.

As previously mentioned, a setting where $\mathrm{p} 38 \mathrm{MAPK}$ and $\mathrm{NFk} \beta$ signaling is stronger leads to an inflammatory response, whereas if PI3K/AKT and ERK dominate, inflammation is dampened [146]. The ability of Lyn to activate PI3k could thereby abrogate the inflammatory response by skewing this balance. In 
addition, $\mathrm{PI}_{3} \mathrm{k}$ signaling is in accordance with the IRF3 activation observed in dendritic cells exposed to complement opsonized HIV in our system.

Interestingly, in our assays complement opsonized HIV led to the upregulation of ERK, but not phospho-ERK, whereas free HIV did the opposite: total ERK was not upregulated, whereas phospho-ERK was. The upregulation of total ERK by complement opsonized HIV could be an indication of a signaling pathway that involves ERK.

Importantly, TLR8 signaling still appeared to be active in dendritic cells exposed to complement opsonized HIV - in fact, MyD88 gene upregulation was even higher in cells exposed to complement opsonized HIV than in cells exposed to free HIV. The activation of TLRs has been shown to stimulate $\mathrm{CR}_{3}$ via and inside-out activation, a signaling via PI3 $\mathrm{k}$ that changes the conformation of $\mathrm{CR}_{3}$ to increase its affinity [162]. This event leads to enhanced outside-in CR3 signaling, which is associated with increased phagocytosis [162], an observation that fits well with the doubling of HIV uptake we have observed when HIV is complement opsonized [174].

In summary, CR3/TLR8 crosstalk likely leads to suppression of danger signaling through a pathway that involves PI3k and AKT and leads to the shift from NFk $\beta$ and IRF1 to IRF3 transcription factor activation (see Figure 25). PI3k/AKT likely contribute to enhanced cell survival. The suppression of danger signaling also decreases the production inflammatory and antiviral factors, as well as inhibiting maturation. Interestingly, the ability of $\mathrm{CR}_{3}$ ligation to dampen danger signaling has also been described for NK cells [173], indicating that this mechanism may be shared by multiple cell types.

\subsection{HIV and the STING pathway}

\subsubsection{IFI16 and cGAS signaling converge in the activation of STING}

Since the discovery of cGAS in 2013, multiple studies have shown that this enzyme is involved in the activation of danger responses to DNA presence in the cell cytoplasm [175]. Later, it has been described that AIM2-like receptors, such as IFI16, can respond to cytoplasmic DNA independently of cGAS [175]. Both cGAS and IFI16 activate STING, which leads to the activation of TBK1 and subsequent activation of IRF3 and $N F k \beta$ and the transcription of antiviral and inflammatory factors [175].

\subsubsection{STING can be involved in a later wave of danger signaling in HIV- exposed dendritic cells}

HIV is able to activate the STING/IFI16/IRF3 pathway via reverse transcription products, and it has been shown that expression of IFI16 correlates with the degree of HIV sensing and IFN production in productively infected primary human macrophages, i.e. their ability to restrict HIV replication [175]. In addition, a polymorphism in IFI16 has been shown to affect CD4 T cell counts and HIV disease progression [176], further supporting the role of IFI16 in HIV pathogenesis. In addition to being part of the STING pathway, it has been suggested that IFI16 can restrict HIV replication in an STING independent manner [175]. 
Consequently, IFI16 and/or STING can be involved in a later wave of responses to HIV, after the virus has initiated reverse transcription. This later wave, if present, would be activated after the TLR8 induced response described above.

\subsubsection{HSV2 signaling through cGAS/STING increases HIV replication}

We found that dendritic cells exposed to HSV2 mounted robust inflammatory and antiviral responses, and that these responses were mediated by the STING pathway. Fascinatingly, HIV infection was vastly enhanced in dendritic cells exposed to HSV2, despite their strong antiviral response.

As previously discussed, HIV replication is dependent on the same transcription factors, $N F k \beta$ and IRFs, that are responsible for danger signaling. Studies indicate that HIV transcription has a higher threshold of IRF activation than the antiviral response, and that individuals with lower IRF levels are better at controlling HIV replication [66]. The strong danger signaling induced by HSV2 could therefore in fact facilitate HIV replication.

We found that complement opsonization of HIV re-routes IRF activation from IRF1 and IRF7 to IRF3 [138]. In addition, HSV2-mediated activation of the STING pathway also activated IRF3. In both these settings, HIV replication was greatly enhanced. All three IRFs - IRF1, IRF7 and IRF3 - share a high degree of homology in their DNA binding domain and have the ability to act as transcription factors for HIV and thereby aid viral replication [177]. Whether there is a causal relationship between the induction of IRF3 specifically and the increase in HIV production remains to be determined.

Interestingly, we found that HSV2 infection was associated with the degradation of SAMHD1, APOBEC 3 G, and TREX1, factors that restrict HIV replication in dendritic cells. SAMHD1 and TREX1 were found to be directly downregulated by cGAS activation. SAMHD1 is an enzyme that degrades dNTPs and RNA in the cytosol, while TREX1 degrades cytosolic DNA. TREX1 has been described as acting as a gatekeeper for STING activation, by degrading cytosolic DNA that would otherwise trigger the STING pathway [178]. Similarly, SAMHD1 has been shown to suppress the PI3K/AKT/IRF3 pathway [75],[179]. Also, SAMHD1 can promote the degradation of DNA at stalled replication forks in the cell, which would otherwise accumulate in the cytosol and trigger STING signaling [180]. Both TREX1 and SAMHD1 play a vital role in cell homeostasis, preventing STING activation in response to low levels of endogenous DNA that leaks into the cytosol, and defects in their function are associated with chronic or autoinflammation [180], [181]. Thus, TREX1 and SAMHD1 have been shown to inhibit the STING pathway, but to our knowledge, this is the first time a negative regulation in the opposite direction has been described. We suggest that the degradation of SAMHD1 and TREX1 may be part of a positive feedback loop that amplifies STING signaling, once STING has been triggered.

In summary, HSV2-mediated signaling through the cGAS/STING pathway facilitates HIV replication by increasing levels of HIV transcription factors such as $\mathrm{IRF}_{3}$ and NFk $\beta$ and/or by degrading HIV restriction factors such as SAMHD1 and TREX1. An illustration of how HSV2 activates the STING pathway in dendritic cells to enhance HIV transcription van be found in Figure 26. 


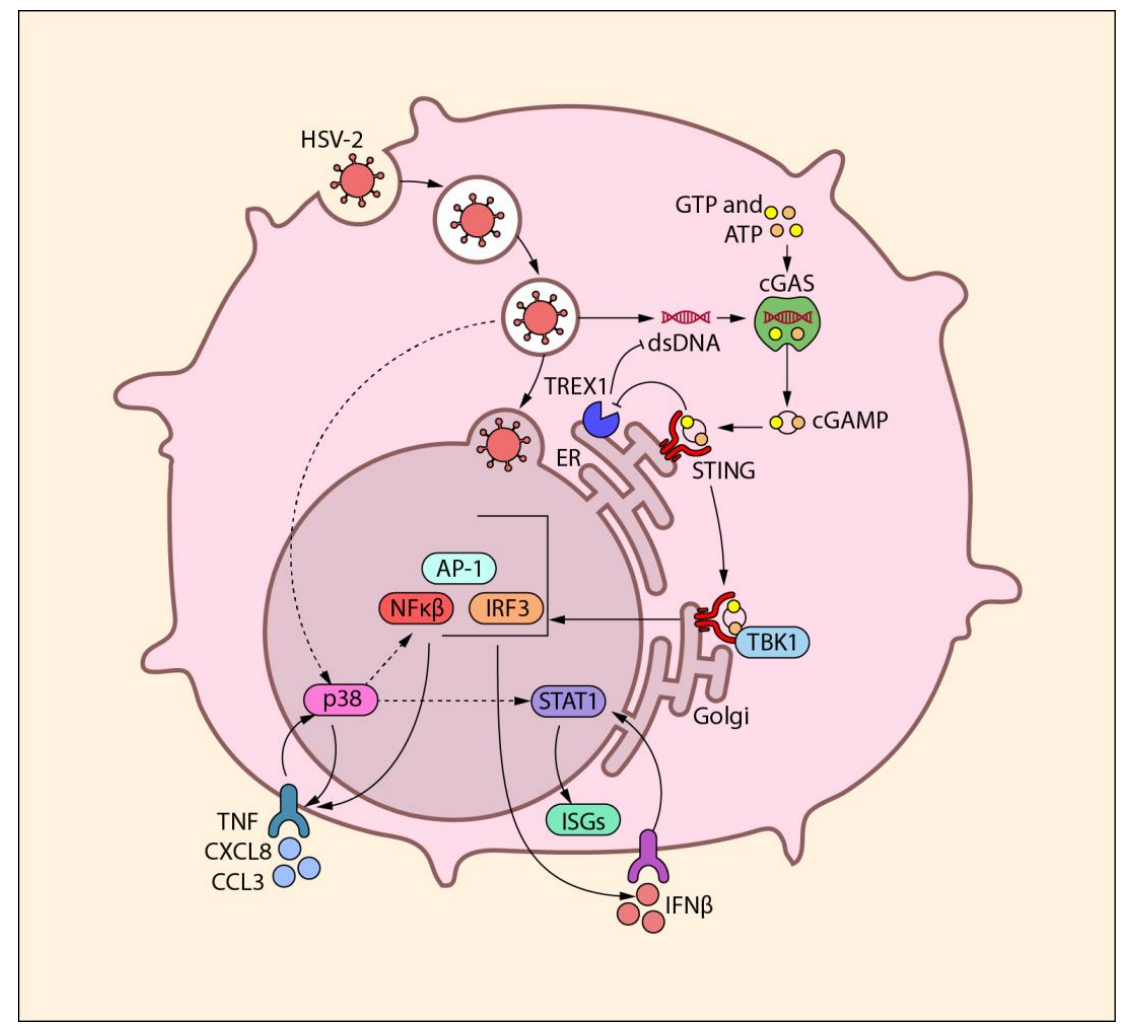

Figure 26. HSV2 activates STING and increases HIV transcription. HSV2 activates the STING pathway in dendritic cells, leading to enhanced HIV transcription. dsDNA derived from HSV2 initiates $c G A M P / S T I N G$ signaling, leading to the activation of $N F k \beta$ and IRF3, which can act as transcription factors for HIV replication. Despite high production of inflammatory and antiviral factors, HIV infection is greatly enhanced.

\subsection{HIV-exposed dendritic cells and NK cells}

A summary of the effect of complement opsonization of HIV on the responses exposed dendritic cells trigger in NK cells can be found in Figure $\mathbf{2 8}$.

\subsubsection{Complement opsonization of HIV suppresses dendritic cell recruitment of NK cells}

The activation and killing ability of NK cells has been associated with protection from HIV infection [182]. Seeing that NK cells, especially at a high NK:target cell ratio, are associated with the killing of infected cells [183], recruiting NK cells to the site of HIV transmission is likely beneficial for the host.

In our system, dendritic cells exposed to free HIV recruited NK cells by secreting CCL3 and CXCL10. However, when HIV was complement opsonized the 
recruitment of NK cells was completely abrogated. The absence of NK cell recruitment can be attributed to the lack of secretion of cytokines that act as chemoattractants for NK cells by dendritic cells exposed to complement opsonized HIV.

\subsubsection{Dendritic cells exposed to complement opsonized HIV suppress NK killing}

HIV-exposed dendritic cells could trigger NK killing through secreted factors, as seen in our experiments where supernatants were used to stimulate NK cells. The ability of dendritic cells to activate NK cell killing was enhanced by cell-cell contact - in NK cells stimulated by supernatants from dendritic cells exposed to free HIV the presence of dendritic cells themselves almost doubled the number of target cells that the NK cells killed. Interestingly, when exposed to supernatants from mocktreated dendritic cells, NK cells did not activate their cytotoxic potential, whereas cell-cell contact with mock-treated dendritic cells led to induction of killing capacity. The dependence of NK cell activation on cell-cell contact with dendritic cells has been described previously [184]. HIV had the ability to suppress this contact-dependent activation.

Factors such as CCL3, IL-12, IL-18 and IL-15 secreted by dendritic cells have been shown to induce killing potential in NK cells [185]. When the cells are in close contact, stimulatory synapses form, allowing polarized secretion of cytokines from the dendritic cell toward the NK-cell [185]. In our studies, dendritic cells exposed to free HIV produced these cytokines, whereas dendritic cells exposed to complement opsonized HIV or mock did not. Differences in cytokine secretion can thus account for the relatively higher killing capacity induced by dendritic cells exposed to free HIV compared to dendritic cells exposed to complement opsonized HIV. In addition, these cytokines have been shown to mediate IFN-driven NK cell activation [185], which we could observe in NK cells allowed to interact with dendritic cells exposed to free HIV.

Cytokines, however, cannot explain the contact-dependent activation seen for mock-treated dendritic cells, nor why this activation was weaker in the presence of HIV. It is likely that this mechanism involves membrane-bound receptor/ligand pairs. While dendritic cells interact with activated NK cells via the NK activation receptor NKp3O, interaction with resting NK cells appears to occur in a NKp3O independent manner [184]. The exact mechanism involved in the contactdependent activation of NK cells in our system remains to be determined.

\subsection{HIV-exposed dendritic cells and T cells}

Overall, in our experiments where we assayed the effect of dendritic cells and NK cells on T cells, the effect of the presence of NK cells was minimal, with one important exception - CXCR3 and CCR4 upregulation, see below. This means that NK cells did not alter the dendritic cell $\mathrm{T}$ cell priming for the majority of factors, and dendritic cells were responsible for most of the T cell stimulation. A summary of the effect of complement opsonization of HIV on the responses exposed dendritic cells trigger in T cells in the presence of NK cells can be found in Figure $\mathbf{2 8}$. 


\subsubsection{HIV-exposed dendritic cells suppress T cell proliferation}

The $\mathrm{T}$ cell phenotype that is induced following interaction with HIV exposed dendritic cells is relevant both for the type of adaptive immune response triggered, the cytotoxic $\mathrm{T}$ cell responses triggered and the susceptibility of $\mathrm{T}$ cells to infection. $\mathrm{T}$ cell activation can be measured both by assaying proliferation, or the cell's ability to divide and multiply when stimulated, and by measuring the expression of activation markers on the cell surface.

In our studies we found that $\mathrm{T}$ cells primed by dendritic cells had an impaired proliferation when HIV was present. We have previously described this phenomenon for free HIV [186]. Complement opsonization of HIV does not appear to affect $\mathrm{T}$ cell proliferation.

\subsubsection{T cells primed by HIV-exposed dendritic cells differentiate into central memory phenotype}

The generation of memory $\mathrm{T}$ cells is essential for the formation of an acquired immune system. Memory $T$ cells are long-lived antigen-specific cells that have been activated by their cognate antigen in a previous infection, ready to mount recall responses. Memory T cells are antigen-specific cells that are formed when the host comes into contact with a pathogen that can last a lifetime, ready to mount recall responses. Central memory T cells reside mainly in the lymph nodes, whereas effector memory T cells reside in the peripheral tissue [187]. While both these cell types have the ability to recirculate via the blood and lymphatics, an additional memory cell type, tissue resident memory T cells, reside in tissue only. Tissue resident memory $\mathrm{T}$ cells can be formed during primary infection, or when central memory $\mathrm{T}$ cells are re-stimulated. In addition, upon stimulation, central memory $\mathrm{T}$ cells can also differentiate into effector memory $\mathrm{T}$ cells and migrate to inflamed tissue where they can display immediate effector functions such as cytotoxicity and cytokine production [187]. Central and effector memory $\mathrm{T}$ cells can be distinguished from naïve $\mathrm{T}$ cells by their expression of $\mathrm{CCR} 7$, a receptor that facilitates homing to lymph, and which isoform of CD45, a molecule involved in TCR signaling they express. Naïve T cells are CCR7+CD45RA+, while central memory cells lose CD45RA and express CD45RO instead, becoming CCR7+CD45RA-. Effector memory $\mathrm{T}$ cells lose CCR7, i.e. their ability to home to lymph, becoming CCR7CD45RA-.

Both CD4 and CD8 T cells primed by HIV exposed dendritic cells differentiated to a central memory (CCR7+CD45RA-) phenotype. Complement opsonization of HIV increased the central memory population further. The differentiation of central memory $\mathrm{T}$ cells is in accordance with what has been observed during acute HIV infection in vivo [188]. This phenotype has been described to have an increased susceptibility to HIV infection [189].

It has been suggested that the strength of the signals delivered by TCR and cytokine receptors during $\mathrm{T}$ cell priming drives $\mathrm{T}$ cells through hierarchical thresholds of differentiation, with the strongest signal giving rise to effector $\mathrm{T}$ cells [187]. Cells that have not received sufficient signal strength will arrest at intermediate stages of differentiation, and these intermediate stages will then resolve into distinct subsets of central and effector memory cells that survive after 
antigen clearance [187]. This hypothesis is illustrated in Figure 27. Dendritic cells exposed to HIV gave rise to fewer effector memory and more central memory T cells than dendritic cells exposed to mock. The model of hierarchical differentiation would therefore imply that HIV suppresses the activating signal provided by the dendritic cell during T cell priming. This hypothesis would fit well with the decreased proliferation capacity seen for T cells primed by HIV-exposed dendritic cells.

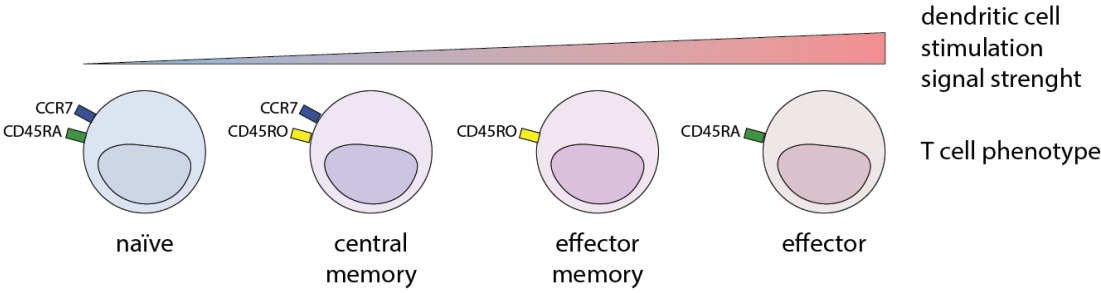

Figure 27. The signal strength hypothesis. It has been suggested that the strength of the activating signals delivered during dendritic cell priming of T cells determines the T cell phenotype by driving the T cells through hierarchical thresholds of differentiation, with the strongest signal giving rise to effector $T$ cells and intermediate stages resolving into memory cells [187].

\subsubsection{Dendritic cells exposed to complement opsonized HIV induce T cells with an exhausted phenotype}

Complement opsonization of HIV increased the co-expression of the negative checkpoint markers PD1, TIM3 and LAG3 on T cells primed by HIV-exposed dendritic cells. PD1 guards against autoimmunity by promoting apoptosis of antigen-specific T cells, while reducing apoptosis in regulatory T cells. Similarly, TIM3 and LAG3 can inhibit immune activation and trigger cell death.

The expression of all three molecules together is a signature of so-called exhausted $\mathrm{T}$ cells, i.e. a type dysfunctional $\mathrm{T}$ cells with impaired ability to react to stimulus associated with many chronic diseases including HIV [190]. Our results indicate that complement opsonization of HIV contributes to the exhaustion of host $\mathrm{T}$ cells and thereby supports HIV pathogenesis.

\subsubsection{Dendritic cells exposed to complement opsonized HIV induce upregulation of CD38 on T cells}

T cells primed by dendritic cells exposed to HIV upregulated their expression of CD38 - CD8 T cells upregulated this marker in response to dendritic cells exposed to all variations of $\mathrm{HIV}$, whereas upregulation on $\mathrm{CD} 4 \mathrm{~T}$ cells was dependent on the presence of complement on the viral surface. CD38 is an activation marker that has been shown to correlate with high viral load and disease progression towards AIDS [16]. In addition, individuals able to control HIV infection have been shown to have a lower frequency of $\mathrm{CD} 38$ expressing T cells [16]. It has been suggested that $\mathrm{CD}_{3} 8$ is associated with a higher expression of HIV co-receptor CCR5, which allows cells to support a higher level of HIV replication [191]. 


\subsubsection{Dendritic cells exposed to complement opsonized HIV induce upregulation of CXCR3 and CCR4 on T cells in the presence of NK cells}

Dendritic cells exposed to complement opsonized HIV stimulated T cells to upregulate CXCR3 and CCR4, whereas dendritic cells exposed to free HIV did not. Interestingly, this upregulation only occurred if NK cells were present during the priming as well. This pattern was present both for CD4 and CD8 T cells, although the number of $\mathrm{CD} 8 \mathrm{~T}$ cells that upregulated these markers were much lower.

$\mathrm{CXCR}_{3}$ and CCR4 are associated with the trafficking and retention of $\mathrm{T}$ cells to inflamed tissue, and cells with these markers have been described to be highly permissive to HIV infection [192], [193]. The upregulation of CXCR3 and CCR4 could be in part mediated by the production of CXCL9, which was upregulated in dendritic cells exposed to complement opsonized HIV. The role of NK cells, however, is currently not clear. 


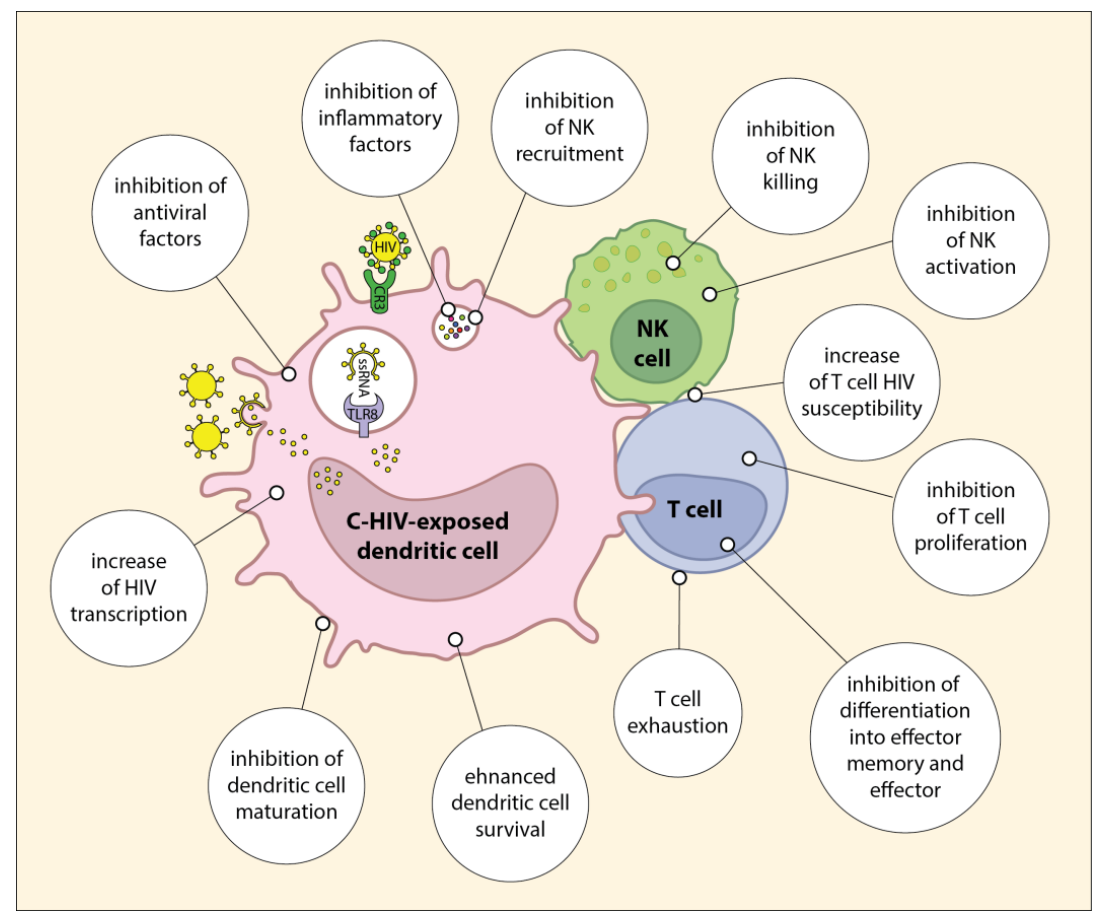

Figure 28. Dendritic cells exposed to complement opsonized HIV have a dysfunctional immune activation and an impaired capacity to activate NK-and Tcells. $i C 3 b$ on the viral surface activates $C_{3} 3$ signaling, which leads to the suppression of TLR8mediated upregulation of danger signaling, including the production of antiviral factors (such as IFN, MXA and IFIT3) and inflammatory cytokines (such as IL-1b, IL-6 and TNF). The lack of cytokines such as CCL3 and CXCL9 leads to absence of NK cell recruitment and activation. In addition, NK cell activation and killing capacity are further suppressed in a contact dependent manner. T cells primed in this setting have reduced proliferation capacity and do not differentiate into memory effector or effector phenotype, which indicates a weak stimulatory signal originating from the dendritic cell. In addition, the cells have an increased expression of markers associated with $T$ cell exhaustion ( $P D-1, T I M_{3}$ and $L A G_{3}$ ) and markers associated with increased susceptibility to HIV infection (CD38,CXCL3 and CCR4). 


\subsection{Concluding remarks}

HIV possesses a remarkable repertoire of immune evasion strategies. Here, we describe HIVs ability to hijack the human complement system and pathways usually used to avoid self-immunity to suppress dendritic cell danger signaling and instead promote a response that favors HIV infection and viral spread and how dendritic cells exposed to complement opsonized HIV inhibit NK mediated killing and suppress T cell activation. We have also described how HIV exploits the presence of HSV2 to enhance dendritic cell HIV infection. Our finding shed light on factors that govern the crossroads between pro- and anti-inflammatory responses and on the regulation of HIV transcription. Given the influence dendritic cells have over HIV exposure outcome in vivo, the mechanisms described in this thesis are likely of importance for HIV pathogenesis.

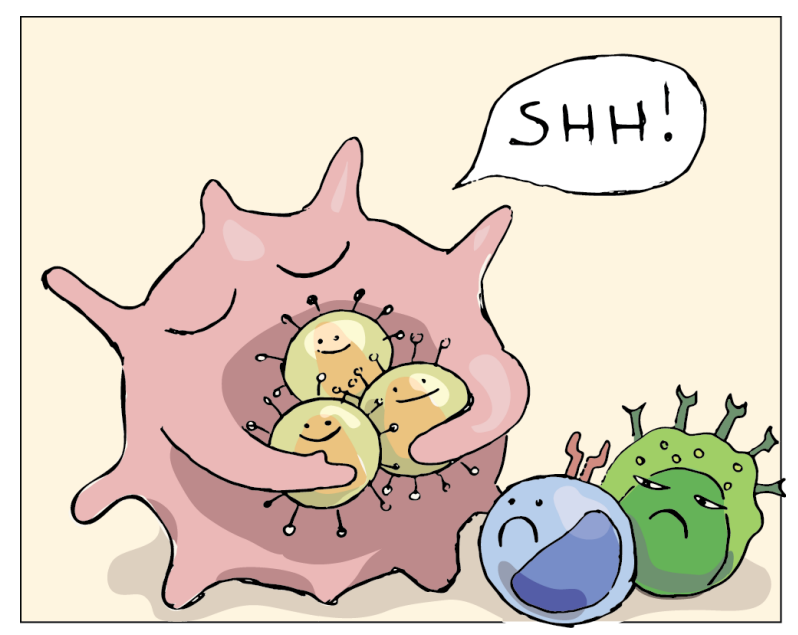

Figure 29. Dendritic cells exposed to complement opsonized HIV suppress immune activation. 


\section{Acknowledgements}

This thesis would not be possible without the inspiration, encouragement and help I received from many wonderful individuals, here are some of them:

The fantastic donors who provided blood or tissue for our experiments: THANK YOU! Without you, none of this research would be possible.

My supervisor Marie Larsson, who has been with me through a decade of fantastic research, mysterious dendritic cell issues, $0.051 \mathrm{p}$ values, unexpected breakthroughs, new methods and the occasional lab-drama - thank you for all your support throughout my degree projects and $\mathrm{PhD}$ !

My co-supervisor Jorma Hinkula, who has been a calm assuring presence throughout my $\mathrm{PhD}$, provided the HIV-specific antibodies we used in all our experiments and given me the opportunity to be part of on his IgM-paper.

My co-supervisor Johan Dabrosin Söderholm, who has taken time off his very busy schedule to meet, has been so enthusiastic about my research, and has been an invaluable help for our colon projects.

The past and present members of the HIV group, especially those who I have had the incredible fortune to share an office with: Cissi (I am utterly confident that you will rock your PhD!), Eli (I am forever grateful that you joined our group, what would have I done without you?) and Karl (you are a truly good person, and spread happiness wherever you go). Sofia, you are probably one of the kindest people I know. Veronica and Vegard, life in the lab was never dull with you around. Shankar, thank you for all the collaborations! Pradyot and Melissa, I wish you all the best in your projects.

My fellow PhD students and fantastic friends: Tina - thank you for all the times you initiated fika and for all the talks! You are such a friendly and down to earth person, I always feel good when I am around you. Josefine - you are awesome. I am so glad we found each other, despite us both being such introverts. Camilla, you must be the most thoughtful and caring person on this planet - always three steps ahead, saying or doing considerate things before I even knew I needed them. Emmy (I am putting you here even though you are not a PhD student - you had to listen to more than enough research stuff) - thank you for the post-Elsa workouts.

The technicians, especially Lotta and Pia: you are the wisest people on floor 13 . How I have wished that one of you was part of our group! Thank you for all the advice and the countless times that you have saved me by lending me reagents when I have run out mid-experiment. Annika and Caroline, you really contributed to a positive and fun atmosphere at work! 
My bioinformatics mentor Katarina Truvé, thank you for the immense interest you have shown for my projects, and for all the help! Also, thank you Mihaela Martis for stimulating bioinformatics discussions.

Mikael Sigvardsson and group for always being so helpful. Tobbe, thank you for teaching me how to analyze ATAC-seq! Rajesh, thank you for always being patient when I was not finished with the flow on time.

Lennart Svensson and group - Johan, Sumit, Marie: thank you for always being super nice to me!

Jan-Ingvar Jönsson and group - Emma, thank you for being so friendly, and sorry for that time that you were left holding Maja while I "quickly" looked for something in the -80 .

Åsa and Annette at core facility: thank you for all your support with the NextSeq!

Robert, thank you for giving me the opportunity to hold lectures on the Infectious Biology course.

My brilliant and sweet T6:or Jonas, Mirja, Ylva and Linnéa, I am glad I got to have you with me.

Åsa Keita, Preben Kjölhede, Ninnie Borendahl, Åsa Rydmark Kersley: thank you for making our tissue projects possible.

My dear fellow biologists from Valla: Kicci, Nea, Elin, Helena, Hanna, Mia, Maria. Thank you for being such wonderful friends, when we were all young and after.

My magnificent new colleagues at klinisk genetik and the NGS platform, I am truly grateful that I get to work together with such intelligent, fabulous individuals.

Finally: my family - my parents, sisters, in-laws (and neighbors). It is not possible to express what you mean to me in a few sentences, so I am not even going to try. Elsa and Maja, if you find this thesis and read the acknowledgements when you are old enough to read: know that I love you infinitely, now and always. You make my heart smile. Also, if you turn to page 34 you can find Maja's contribution to this thesis, ej§§. Sander, you are the best person I know. Thank you for being there. 


\section{$7 \quad$ References}

[1] AVERT, "History of HIV and AIDS overview."

[2] M. Roser and H. Ritchie, "HIV / AIDS - Our World in Data," 2018.

[3] Unaids, "Fact sheet - Latest global and regional statistics on the status of the AIDS epidemic."

[4] "FACTSHEET: Africa's leading causes of death | Africa Check." [Online]. Available: https://africacheck.org/factsheets/factsheet-africas-leading-causesdeath/. [Accessed: 11-May-2018].

[5] G. A. C. B. (Arbeitskreis German Advisory Committee Blood (Arbeitskreis Blut), Subgroup 'Assessment of Pathogens Transmissible by Blood' and S. 'Assessment of P. T. by Blood', "Human Immunodeficiency Virus (HIV).," Transfus. Med. Hemother., vol. 43, no. 3, pp. 203-22, May 2016.

[6] K. Raehtz, I. Pandrea, and C. Apetrei, "The well-tempered SIV infection: Pathogenesis of SIV infection in natural hosts in the wild, with emphasis on virus transmission and early events post-infection that may contribute to protection from disease progression," Infect. Genet. Evol., vol. 46, pp. 308-323, Dec. 2016.

[7] T. Hatziioannou and D. T. Evans, "Animal models for HIV/AIDS research.," Nat. Rev. Microbiol., vol. 10, no. 12, pp. 852-67, Dec. 2012.

[8] E. Vicenzi, P. Liò, and G. Poli, "The puzzling role of CXCR4 in human immunodeficiency virus infection.," Theranostics, vol. 3, no. 1, pp. 18-25, 2013.

[9] L. Margolis and R. Shattock, "Selective transmission of CCR5-utilizing HIV-1: the 'gatekeeper' problem resolved?," Nat. Rev. Microbiol., vol. 4, no. 4, pp. 312317, Apr. 2006.

[10] A. Antiretroviral Therapy Cohort Collaboration et al., "Survival of HIV-positive patients starting antiretroviral therapy between 1996 and 2013: a collaborative analysis of cohort studies.," lancet. HIV, vol. 4, no. 8, pp. e349-e356, Aug. 2017.

[11] C. Frezza, S. Grelli, M. Federico, F. Marino-Merlo, A. Mastino, and B. Macchi, "Testing anti-HIV activity of antiretroviral agents in vitro using flow cytometry analysis of CEM-GFP cells infected with transfection-derived HIV-1 NL4-3," $J$. Med. Virol., vol. 88, no. 6, pp. 979-986, Jun. 2016.

[12] B. F. Haynes, "Gut microbes out of control in HIV infection," Nat. Med., vol. 12, no. 12, pp. 1351-1352, Dec. 2006.

[13] M. D. Hazenberg et al., "Persistent immune activation in HIV-1 infection is associated with progression to AIDS.," AIDS, vol. 17, no. 13, pp. 1881-8, Sep. 2003.

[14] “CDC's HIV Basics | HIV.gov.” [Online]. Available: https://www.hiv.gov/authors/cdc-s-hiv-basics. [Accessed: 06-May-2018].

[15] D. T. Imagawa et al., "Human Immunodeficiency Virus Type 1 Infection in Homosexual Men Who Remain Seronegative for Prolonged Periods," N. Engl. J. Med., vol. 320, no. 22, pp. 1458-1462, Jun. 1989.

[16] S. M. Gonzalez, N. A. Taborda, and M. T. Rugeles, "Role of Different Subpopulations of CD8+ T Cells during HIV Exposure and Infection," Front. Immunol., vol. 8, p. 936, Aug. 2017.

[17] B. D. Walker, "Elite control of HIV Infection: implications for vaccines and treatment.," Top. HIV Med., vol. 15, no. 4, pp. 134-6.

[18] V. Müller, C. Fraser, and J. T. Herbeck, "A strong case for viral genetic factors in HIV virulence.," Viruses, vol. 3, no. 3, pp. 204-16, Mar. 2011.

[19] M. L. Robb et al., "Prospective Study of Acute HIV-1 Infection in Adults in East Africa and Thailand," N. Engl. J. Med., vol. 374, no. 22, pp. 2120-2130, Jun. 2016.

[20] R. J. Shattock and J. P. Moore, "Inhibiting sexual transmission of HIV-1 infection," Nat. Rev. Microbiol., vol. 1, no. 1, pp. 25-34, Oct. 2003.

[21] D. T. Dunn, M. L. Newell, A. E. Ades, and C. S. Peckham, "Risk of human immunodeficiency virus type 1 transmission through breastfeeding.," Lancet (London, England), vol. 340, no. 8819, pp. 585-8, Sep. 1992.

[22] F. Hladik and T. J. Hope, "HIV infection of the genital mucosa in women.," Curr. HIV/AIDS Rep., vol. 6, no. 1, pp. 20-8, Feb. 2009. 
[23] W. Lu et al., "Virus-host mucosal interactions during early SIV rectal transmission," Virology, vol. 464-465, pp. 406-414, Sep. 2014.

[24] P. Patel, C. B. Borkowf, J. T. Brooks, A. Lasry, A. Lansky, and J. Mermin, "Estimating per-act HIV transmission risk: a systematic review.," AIDS, vol. 28, no. 10, pp. 1509-19, Jun. 2014.

[25] Unaids, "Global AIDS Update 2016," 2016.

[26] D. T. Halperin and H. Epstein, "Concurrent sexual partnerships help to explain Africa's high HIV prevalence: implications for prevention.," Lancet (London, England), vol. 364, no. 9428, pp. 4-6, Jul. 2004.

[27] A. N. Harman, M. Kim, N. Nasr, K. J. Sandgren, and P. U. Cameron, "Tissue dendritic cells as portals for HIV entry," Rev. Med. Virol., vol. 23, no. 5, pp. 319333, Sep. 2013.

[28] A. T. Haase, "Early Events in Sexual Transmission of HIV and SIV and Opportunities for Interventions," Annu. Rev. Med., vol. 62, no. 1, pp. 127-139, Feb. 2011.

[29] M. Stone et al., "A limited number of simian immunodeficiency virus (SIV) env variants are transmitted to rhesus macaques vaginally inoculated with SIVmac251.," J. Virol., vol. 84, no. 14, pp. 7083-95, Jul. 2010.

[30] D. J. Stieh et al., "Vaginal Challenge with an SIV-Based Dual Reporter System Reveals That Infection Can Occur throughout the Upper and Lower Female Reproductive Tract," PLoS Pathog., vol. 10, no. 10, p. e1004440, Oct. 2014.

[31] Q. Li et al., "Glycerol monolaurate prevents mucosal SIV transmission," Nature, vol. 458, no. 7241, pp. 1034-1038, Apr. 2009.

[32] I. Mellman and R. M. Steinman, "Dendritic cells: specialized and regulated antigen processing machines.," Cell, vol. 106, no. 3, pp. 255-8, Aug. 2001.

[33] N. Hertoghs, T. B. H. Geijtenbeek, and C. M. S. Ribeiro, "Interplay between HIV1 innate sensing and restriction in mucosal dendritic cells: balancing defense and viral transmission," Curr. Opin. Virol., vol. 22, pp. 112-119, Feb. 2017.

[34] R. M. Steinman, "The dendritic cell system and its role in immunogenicity.," Annu. Rev. Immunol., vol. 9, pp. 271-96, Jan. 1991.

[35] C. Reis e Sousa, "Dendritic cells in a mature age.," Nat. Rev. Immunol., vol. 6, no. 6 , pp. $476-83$, Jun. 2006.

[36] D. Alvarez, E. H. Vollmann, and U. H. von Andrian, "Mechanisms and consequences of dendritic cell migration.," Immunity, vol. 29, no. 3, pp. 325-42, Sep. 2008.

[37] G. Schreibelt et al., "Toll-like receptor expression and function in human dendritic cell subsets: implications for dendritic cell-based anti-cancer immunotherapy," Cancer Immunol. Immunother., vol. 59, no. 10, pp. 15731582, Oct. 2010.

[38] H. D. de Koning et al., "A Comprehensive Analysis of Pattern Recognition Receptors in Normal and Inflamed Human Epidermis: Upregulation of Dectin-1 in Psoriasis," J. Invest. Dermatol., vol. 130, no. 11, pp. 2611-2620, Nov. 2010.

[39] K. Clayton, A. F. Vallejo, J. Davies, S. Sirvent, and M. E. Polak, "Langerhans Cells-Programmed by the Epidermis.," Front. Immunol., vol. 8, p. 1676, 2017.

[40] N. Mizumoto and A. Takashima, "CD1a and langerin: acting as more than Langerhans cell markers.,” J. Clin. Invest., vol. 113, no. 5, pp. 658-6o, Mar. 2004.

[41] J. K. Krishnaswamy, T. Chu, and S. C. Eisenbarth, "Beyond pattern recognition: NOD-like receptors in dendritic cells.," Trends Immunol., vol. 34, no. 5, pp. 224-33, May 2013.

[42] E. J. Soilleux et al., "Constitutive and induced expression of DC-SIGN on dendritic cell and macrophage subpopulations in situ and in vitro.," J. Leukoc. Biol., vol. 71, no. 3, pp. 445-57, Mar. 2002.

[43] D. Duluc et al., "Transcriptional fingerprints of antigen-presenting cell subsets in the human vaginal mucosa and skin reflect tissue-specific immune microenvironments.," Genome Med., vol. 6, no. 11, p. 98, 2014.

[44] C. Mattmann et al., "Hematopoietic Cells Differential Expression of NLRP3 among," J Immunol, vol. 186, pp. 2529-2534, 2018.

[45] M. Kato et al., "Expression of human DEC-205 (CD205) multilectin receptor on leukocytes," Int. Immunol., vol. 18, no. 6, pp. 857-869, Jun. 2006. 
[46] J. Valladeau et al., "Immature human dendritic cells express asialoglycoprotein receptor isoforms for efficient receptor-mediated endocytosis.," J. Immunol., vol. 167, no. 10, pp. 5767-74, Nov. 2001.

[47] Y. Delneste et al., "Involvement of LOX-1 in Dendritic Cell-Mediated Antigen Cross-Presentation," Immunity, vol. 17, no. 3, pp. 353-362, Sep. 2002.

[48] A. Yasen, R. Herrera, K. Rosbe, K. Lien, and S. M. Tugizov, "Release of HIV-1 sequestered in the vesicles of oral and genital mucosal epithelial cells by epithelial-lymphocyte interaction.," PLoS Pathog., vol. 13, no. 2, p. e1006247, Feb. 2017.

[49] R. H. Gray et al., "Male circumcision for HIV prevention in men in Rakai, Uganda: a randomised trial," Lancet, vol. 369, no. 9562, pp. 657-666, Feb. 2007.

[5o] M. H. Dinh et al., "Visualization of HIV-1 Interactions with Penile and Foreskin Epithelia: Clues for Female-to-Male HIV Transmission," PLOS Pathog., vol. 11, no. 3, p. e1004729, Mar. 2015.

[51] M. Rescigno et al., "Dendritic cells express tight junction proteins and penetrate gut epithelial monolayers to sample bacteria," Nat. Immunol., vol. 2, no. 4, pp. 361-367, Apr. 2001.

[52] F. Hladik and M. J. McElrath, "Setting the stage: host invasion by HIV.," Nat. Rev. Immunol., vol. 8, no. 6, pp. 447-57, Jun. 2008.

[53] J. Hu, M. B. Gardner, and C. J. Miller, "Simian immunodeficiency virus rapidly penetrates the cervicovaginal mucosa after intravaginal inoculation and infects intraepithelial dendritic cells.," J. Virol., vol. 74, no. 13, pp. 6087-95, Jul. 2000.

[54] S. G. Turville et al., "Immunodeficiency virus uptake, turnover, and 2-phase transfer in human dendritic cells," Blood, vol. 103, no. 6, pp. 2170-2179, Mar. 2004.

[55] L. Bracq, M. Xie, S. Benichou, and J. Bouchet, "Mechanisms for Cell-to-Cell Transmission of HIV-1," Front. Immunol., vol. 9, Feb. 2018.

[56] A. J. Masterson et al., "MUTZ-3, a human cell line model for the cytokineinduced differentiation of dendritic cells from CD34+ precursors.," Blood, vol. 100, no. 2, pp. 701-3, Jul. 2002.

[57] M. Deruaz et al., "Chemoattractant-mediated leukocyte trafficking enables HIV dissemination from the genital mucosa," JCI Insight, vol. 2, no. 7, p. e88533, Apr. 2017.

[58] R. A. Koup et al., "Temporal association of cellular immune responses with the initial control of viremia in primary human immunodeficiency virus type 1 syndrome.," J. Virol., vol. 68, no. 7, pp. 4650-5, Jul. 1994.

[59] D. Ivanova, R. Krempels, J. Ryfe, K. Weitzman, D. Stephenson, and J. P. Gigley, "NK Cells in Mucosal Defense against Infection," Biomed Res. Int., vol. 2014, pp. $1-11,2014$.

[6o] N. Huot et al., "Natural killer cells migrate into and control simian immunodeficiency virus replication in lymph node follicles in African green monkeys," Nat. Med., vol. 23, no. 11, pp. 1277-1286, Oct. 2017.

[61] G. Alter and M. Altfeld, "NK cells in HIV-1 infection: evidence for their role in the control of HIV-1 infection.," J. Intern. Med., vol. 265, no. 1, pp. 29-42, Jan. 2009.

[62] C. Tomescu, S. Abdulhaqq, and L. J. Montaner, "Evidence for the innate immune response as a correlate of protection in human immunodeficiency virus (HIV)-1 highly exposed seronegative subjects (HESN).," Clin. Exp. Immunol., vol. 164, no. 2, pp. 158-69, May 2011.

[63] B. Morandi et al., "Dendritic Cell Editing by Activated Natural Killer Cells Results in a More Protective Cancer-Specific Immune Response," PLoS One, vol. 7, no. 6, p. e39170, Jun. 2012.

[64] M. Altfeld, L. Fadda, D. Frleta, and N. Bhardwaj, "DCs and NK cells: critical effectors in the immune response to HIV-1.," Nat. Rev. Immunol., vol. 11, no. 3 , pp. 176-86, Mar. 2011.

[65] K. Kaczmarek, A. Morales, and A. J. Henderson, "T Cell Transcription Factors and Their Impact on HIV Expression.," Virology (Auckl)., vol. 2013, no. 4, pp. 41-47, Sep. 2013.

[66] R.-C. Su et al., "Reducing IRF-1 to Levels Observed in HESN Subjects Limits HIV Replication, But Not the Extent of Host Immune Activation.," Mol. Ther. 
Nucleic Acids, vol. 4, no. 10, p. e259, Oct. 2015.

[67] J. Hiscott, H. Kwon, and P. Génin, "Hostile takeovers: viral appropriation of the NF-kappaB pathway.,” J. Clin. Invest., vol. 107, no. 2, pp. 143-51, Jan. 2001.

[68] A. Meier et al., "MyD88-Dependent Immune Activation Mediated by Human Immunodeficiency Virus Type 1-Encoded Toll-Like Receptor Ligands," J. Virol., vol. 81, no. 15, pp. 8180-8191, Aug. 2007.

[69] E. Colak et al., "RNA and imidazoquinolines are sensed by distinct TLR7/8 ectodomain sites resulting in functionally disparate signaling events.," $J$. Immunol., vol. 192, no. 12, pp. 5963-73, Jun. 2014.

[70] H. Hofmann, B. Vanwalscappel, N. Bloch, and N. R. Landau, "TLR7/8 agonist induces a post-entry SAMHD1-independent block to HIV-1 infection of monocytes," Retrovirology, vol. 13, no. 1, p. 83, Dec. 2016.

[71] E. Khatamzas et al., "Snapin promotes HIV-1 transmission from dendritic cells by dampening TLR8 signaling.," EMBO J., vol. 36, no. 20, pp. 2998-3011, Oct. 2017.

[72] D. Gao et al., "Cyclic GMP-AMP synthase is an innate immune sensor of HIV and other retroviruses.," Science, vol. 341, no. 6148, pp. 903-6, Aug. 2013.

[73] D. C. Goldstone et al., "HIV-1 restriction factor SAMHD1 is a deoxynucleoside triphosphate triphosphohydrolase," Nature, vol. 480, no. 7377, pp. 379-382, Dec. 2011.

[74] N. Yan, A. D. Regalado-Magdos, B. Stiggelbout, M. A. Lee-Kirsch, and J. Lieberman, "The cytosolic exonuclease TREX1 inhibits the innate immune response to human immunodeficiency virus type 1.," Nat. Immunol., vol. 11, no. 11, pp. 1005-13, Nov. 2010.

[75] S. Chen et al., "SAMHD1 suppresses innate immune responses to viral infections and inflammatory stimuli by inhibiting the NF- $\mathrm{kB}$ and interferon pathways.," Proc. Natl. Acad. Sci. U. S. A., vol. 115, no. 16, pp. E3798-E3807, Apr. 2018.

[76] J. P. Donahue, M. L. Vetter, N. A. Mukhtar, and R. T. D’Aquila, "The HIV-1 Vif PPLP motif is necessary for human APOBEC $3 \mathrm{G}$ binding and degradation.," Virology, vol. 377, no. 1, pp. 49-53, Jul. 2008.

[77] R. S. Harris et al., "DNA deamination mediates innate immunity to retroviral infection.," Cell, vol. 113, no. 6, pp. 803-9, Jun. 2003.

[78] T. Tada et al., "MARCH8 inhibits HIV-1 infection by reducing virion incorporation of envelope glycoproteins," Nat. Med., vol. 21, no. 12, pp. 15021507, Dec. 2015.

[79] C. Krapp et al., "Guanylate Binding Protein (GBP) 5 Is an Interferon-Inducible Inhibitor of HIV-1 Infectivity," Cell Host Microbe, vol. 19, no. 4, pp. 504-514, Apr. 2016.

[80] N. Nasr et al., "Mechanism of Interferon-Stimulated Gene Induction in HIV-1Infected Macrophages.," J. Virol., vol. 91, no. 20, pp. eoo744-17, Oct. 2017.

[81] S. J. D. Neil, T. Zang, and P. D. Bieniasz, "Tetherin inhibits retrovirus release and is antagonized by HIV-1 Vpu," Nature, vol. 451, no. 7177, pp. 425-430, Jan. 2008.

[82] A. A. Compton et al., "IFITM Proteins Incorporated into HIV-1 Virions Impair Viral Fusion and Spread," Cell Host Microbe, vol. 16, no. 6, pp. 736-747, Dec. 2014.

[83] V. Rodrigues, N. Ruffin, M. San-Roman, and P. Benaroch, "Myeloid Cell Interaction with HIV: A Complex Relationship," Front. Immunol., vol. 8, p. 1698, Nov. 2017.

[84] V. Naranbhai and M. Carrington, "Host genetic variation and HIV disease: from mapping to mechanism.," Immunogenetics, vol. 69, no. 8-9, pp. 489-498, 2017.

[85] Y. Huang et al., "The role of a mutant CCR5 allele in HIV-1 transmission and disease progression," Nat. Med., vol. 2, no. 11, pp. 1240-1243, Nov. 1996.

[86] R. D. Mackelprang et al., "Host genetic and viral determinants of HIV-1 RNA set point among HIV-1 seroconverters from sub-saharan Africa.," J. Virol., vol. 89, no. 4, pp. 2104-11, Feb. 2015.

[87] R. D. Mackelprang et al., "Host genetic and viral determinants of HIV-1 RNA set point among HIV-1 seroconverters from sub-saharan Africa.," J. Virol., vol. 89, no. 4, pp. 2104-11, Feb. 2015.

[88] M. Biasin et al., "TLR activation pathways in HIV-1-exposed seronegative 
individuals.," J. Immunol., vol. 184, no. 5, pp. 2710-7, Mar. 2010.

[89] J. A. Fulcher et al., "Highly Human Immunodeficiency Virus-Exposed Seronegative Men Have Lower Mucosal Innate Immune Reactivity.," AIDS Res. Hum. Retroviruses, vol. 33, no. 8, pp. 788-795, Aug. 2017.

[90] A. Ciuffi et al., "Entry and transcription as key determinants of differences in CD4 T-cell permissiveness to human immunodeficiency virus type 1 infection.," J. Virol., vol. 78, no. 19, pp. 10747-54, Oct. 2004.

[91] J. Arthos et al., "The Role of Integrin $\alpha_{4} \beta 7$ in HIV Pathogenesis and Treatment," Curr. HIV/AIDS Rep., vol. 15, no. 2, pp. 127-135, Apr. 2018.

[92] S. Rato, A. Rausell, M. Muñoz, A. Telenti, and A. Ciuffi, "Single-cell analysis identifies cellular markers of the HIV permissive cell.," PLoS Pathog., vol. 13, no. 10, p. e1006678, Oct. 2017.

[93] V. Joag et al., "Ex vivo HIV entry into blood CD4+ T cells does not predict heterosexual HIV acquisition in women.," PLoS One, vol. 13, no. 7, p. e0200359, 2018.

[94] E. E. Freeman, H. A. Weiss, J. R. Glynn, P. L. Cross, J. A. Whitworth, and R. J. Hayes, "Herpes simplex virus 2 infection increases HIV acquisition in men and women: systematic review and meta-analysis of longitudinal studies.," AIDS, vol. 20, no. 1, pp. 73-83, Jan. 2006.

[95] N. O'Farrell, "Increasing prevalence of genital herpes in developing countries: implications for heterosexual HIV transmission and STI control programmes.," Sex. Transm. Infect., vol. 75, no. 6, pp. 377-84, Dec. 1999.

[96] J. Zhu et al., "Persistence of HIV-1 receptor-positive cells after HSV2 reactivation is a potential mechanism for increased HIV-1 acquisition," Nat. Med., vol. 15, no. 8, pp. 886-892, Aug. 2009.

[97] G. Pollara et al., "Herpes Simplex Virus Infection of Dendritic Cells: Balance among Activation, Inhibition, and Immunity," J. Infect. Dis., vol. 187, no. 2, pp. 165-178, Jan. 2003.

[98] M. K. Pangburn and H. J. Müller-Eberhard, "Relation of putative thioester bond in $\mathrm{C}_{3}$ to activation of the alternative pathway and the binding of $\mathrm{C}_{3} \mathrm{~b}$ to biological targets of complement.," J. Exp. Med., vol. 152, no. 4, pp. 1102-14, Oct. 1980.

[99] H. Stoiber, L. Kacani, C. Speth, R. Würzner, and M. P. Dierich, "The supportive role of complement in HIV pathogenesis.," Immunol. Rev., vol. 180, pp. 168-76, Apr. 2001.

[10o] M. C. Carroll, "The complement system in regulation of adaptive immunity.," Nat. Immunol., vol. 5, no. 10, pp. 981-6, Oct. 2004.

[101] A. F. Ochsenbein, D. D. Pinschewer, B. Odermatt, M. C. Carroll, H. Hengartner, and R. M. Zinkernagel, "Protective T Cell-Independent Antiviral Antibody Responses Are Dependent on Complement," J. Exp. Med., vol. 190, no. 8, pp. 1165-1174, Oct. 1999.

[102] M. Ramadass, B. Ghebrehiwet, R. J. Smith, and R. R. Kew, "Generation of multiple fluid-phase $\mathrm{C}_{3}$ b:plasma protein complexes during complement activation: possible implications in $\mathrm{C}_{3}$ glomerulopathies.," J. Immunol., vol. 192, no. 3, pp. 1220-30, Feb. 2014.

[103] S. Nagata, R. Hanayama, and K. Kawane, "Autoimmunity and the Clearance of Dead Cells," Cell, vol. 140, no. 5, pp. 619-630, Mar. 2010.

[104] L. C. Korb and J. M. Ahearn, "C1q binds directly and specifically to surface blebs of apoptotic human keratinocytes: complement deficiency and systemic lupus erythematosus revisited.," J. Immunol., vol. 158, no. 10, pp. 4525-4528, May 1997.

[105] C. F. Ebenbichler, N. M. Thielens, R. Vornhagen, P. Marschang, G. J. Arlaud, and M. P. Dierich, "Human immunodeficiency virus type 1 activates the classical pathway of complement by direct $\mathrm{C} 1$ binding through specific sites in the transmembrane glycoprotein gp41.," J. Exp. Med., vol. 174, no. 6, pp. 1417-24, Dec. 1991.

[106] C. Süsal, M. Kirschfink, M. Kröpelin, V. Daniel, and G. Opelz, "Complement activation by recombinant HIV-1 glycoprotein gp120.," J. Immunol., vol. 152, no. 12, pp. 6028-34, Jun. 1994.

[107] G. T. Spear, M. Saifuddin, Y. Zhang, H. Gewurz, and M. L. Hart, "Interaction of mannose-binding lectin with primary isolates of human immunodeficiency virus 
type 1," J. Gen. Virol., vol. 81, no. 4, pp. 949-955, Apr. 2000.

[108] R. M. Bartholomew and A. F. Esser, "Differences in activation of human and guinea pig complement by retroviruses," vol. 121, no. 5, pp. 1748-1751, 1978.

[109] P. Agrawal, R. Nawadkar, H. Ojha, J. Kumar, and A. Sahu, "Complement Evasion Strategies of Viruses: An Overview.,” Front. Microbiol., vol. 8, p. 1117, 2017.

[110] H. Stoiber, Z. Banki, D. Wilflingseder, and M. P. Dierich, "Complement-HIV interactions during all steps of viral pathogenesis.," Vaccine, vol. 26, no. 24, pp. 3046-54, Jun. 2008.

[111] C. J. Parker, "Regulation of Complement by Membrane Proteins: An Overview," Springer, Berlin, Heidelberg, 1992, pp. 1-6.

[112] H. Stoiber, R. Schneider, J. Janatova, and M. P. Dierich, "Human complement proteins $\mathrm{C}_{3} \mathrm{~b}, \mathrm{C} 4 \mathrm{~b}$, factor $\mathrm{H}$ and properdin react with specific sites in gp120 and gp41, the envelope proteins of HIV-1.," Immunobiology, vol. 193, no. 1, pp. 98113, Jun. 1995.

[113] L. M. Hook, J. M. Lubinski, M. Jiang, M. K. Pangburn, and H. M. Friedman, "Herpes simplex virus type 1 and 2 glycoprotein C prevents complementmediated neutralization induced by natural immunoglobulin M antibody.," $J$. Virol., vol. 8o, no. 8, pp. 4038-46, Apr. 2006.

[114] R. Tal-Singer et al., "Herpes simplex virus glycoprotein $\mathrm{C}$ is a receptor for complement component iC3b.," J. Infect. Dis., vol. 164, no. 4, pp. 750-3, Oct. 1991.

[115] E. Crisci et al., "Complement opsonization promotes herpes simplex virus 2 infection of human dendritic cells," J. Virol., vol. 90, no. 10, 2016.

[116] B. L. Myones, J. G. Dalzell, N. Hogg, and G. D. Ross, "Neutrophil and monocyte cell surface p150,95 has iC3b-receptor (CR4) activity resembling CR3.," J. Clin. Invest., vol. 82, no. 2, pp. 640-51, Aug. 1988.

[117] M. Michishita, V. Videm, and M. Amin Arnaout, "A novel divalent cation-binding site in the a domain of the $\beta_{2}$ integrin $\mathrm{CR}_{3}(\mathrm{CD} 11 \mathrm{~b} / \mathrm{CD} 18$ ) is essential for ligand binding," Cell, vol. 72, no. 6, pp. 857-867, Mar. 1993.

[118] A. Hermanowski-Vosatka, P. A. Detmers, O. Götze, S. C. Silverstein, and S. D. Wright, "Clustering of ligand on the surface of a particle enhances adhesion to receptor-bearing cells.," J. Biol. Chem., vol. 263, no. 33, pp. 17822-7, Nov. 1988.

[119] S. Xu, J. Wang, J.-H. Wang, T. A. Springer, A. Nicholson-Weller, and T. VorupJensen, "Distinct recognition of complement $\mathrm{iC}_{3} \mathrm{~b}$ by integrins $\alpha$. ."

[120] N. Sándor, K. Kristóf, K. Paréj, D. Pap, A. Erdei, and Z. Bajtay, "CR3 is the dominant phagocytotic complement receptor on human dendritic cells," Immunobiology, vol. 218, no. 4, pp. 652-663, 2013.

[121] S. Lukácsi, Z. Nagy-Baló, N. Sándor, and Z. Bajtay, "The role of $\mathrm{CR}_{3}$ (CD11b/CD18) and CR4 (CD11c/CD18) in complement-mediated phagocytosis and podosome formation by human phagocytes," Immunol. Lett., vol. 189, pp. 64-72, Sep. 2017.

[122] A. Erdei, S. Lukácsi, B. Mácsik-Valent, Z. Nagy-Baló, I. Kurucz, and Z. Bajtay, "Non-identical twins: Different faces of $\mathrm{CR}_{3}$ and $\mathrm{CR}_{4}$ in myeloid and lymphoid cells of mice and men," Semin. Cell Dev. Biol., Nov. 2017.

[123] G. D. Ross, S. L. Newman, J. D. Lambris, J. E. Devery-Pocius, J. A. Cain, and P. J. Lachmann, "Generation of three different fragments of bound $\mathrm{C}_{3}$ with purified factor I or serum. II. Location of binding sites in the $\mathrm{C}_{3}$ fragments for factors $\mathrm{B}$ and H, complement receptors, and bovine conglutinin.," J. Exp. Med., vol. 158, no. 2, pp. 334-52, Aug. 1983.

[124] R. G. Q. Leslie and S. Hansen, "Complement Receptors," in Encyclopedia of Life Sciences, Chichester, UK: John Wiley \& Sons, Ltd, 2009.

[125] R. Ellegård et al., "Complement opsonization of HIV-1 results in decreased antiviral and inflammatory responses in immature dendritic cells via CR3.," $J$. Immunol., vol. 193, no. 9, pp. 4590-601, Nov. 2014.

[126] W. Posch et al., "Complement-Opsonized HIV-1 Overcomes Restriction in Dendritic Cells.," PLoS Pathog., vol. 11, no. 6, p. e1005005, Jun. 2015.

[127] S. K. Mercier et al., "The Microvesicle Component of HIV-1 Inocula Modulates Dendritic Cell Infection and Maturation and Enhances Adhesion to and Activation of T Lymphocytes," PLoS Pathog., vol. 9, no. 10, p. e1003700, Oct. 2013. 
[128] M. Bhargava, J. M. Cajas, M. A. Wainberg, M. B. Klein, and N. Pant Pai, “Do HIV-1 non-B subtypes differentially impact resistance mutations and clinical disease progression in treated populations? Evidence from a systematic review.," J. Int. AIDS Soc., vol. 17, p. 18944, 2014.

[129] R. H. Dennin and K. Dalhoff, "HIV p24 antigen concentration in serum of 11 anti-HIV 1-positive patients before and after immune-complex dissociation: a study of a 5-year period," Clin. Diagn. Virol., vol. 3, no. 2, pp. 131-137, Feb. 1995.

[130] S. R. Brock and M. J. Parmely, "Francisella tularensis Confronts the Complement System.," Front. Cell. Infect. Microbiol., vol. 7, p. 523, 2017.

[131] H. Bouhlal et al., "Opsonization of HIV with complement enhances infection of dendritic cells and viral transfer to CD4 T cells in a CR3 and DC-SIGNdependent manner.," J. Immunol., vol. 178, no. 2, pp. 1086-95, Jan. 2007.

[132] V. Tjomsland, R. Ellegård, K. Che, J. Hinkula, J. D. Lifson, and M. Larsson, "Complement opsonization of HIV-1 enhances the uptake by dendritic cells and involves the endocytic lectin and integrin receptor families," PLoS One, vol. 6, no. 8, 2011.

[133] M. Pruenster et al., "C-type lectin-independent interaction of complement opsonized HIV with monocyte-derived dendritic cells.," Eur. J. Immunol., vol. 35, no. 9, pp. 2691-8, Sep. 2005.

[134] V. Tjomsland et al., "Blocking of integrins inhibits HIV-1 infection of human cervical mucosa immune cells with free and complement-opsonized virions," Eur. J. Immunol., vol. 43, no. 9, 2013.

[135] M. A. MOORE, Z. W. HAKKI, R. L. GREGORY, L. E. GFELL, W. K. KIM-PARK, and M. J. KOWOLIK, "Influence of Heat Inactivation of Human Serum on the Opsonization of Streptococcus mutans," Ann. N. Y. Acad. Sci., vol. 832, no. 1 Phagocytes, pp. 383-393, Dec. 1997.

[136] M. F. Perdomo, W. Hosia, A. Jejcic, G. L. Corthals, and A. Vahlne, "Human serum protein enhances HIV-1 replication and up-regulates the transcription factor AP-1.," Proc. Natl. Acad. Sci. U. S. A., vol. 109, no. 43, pp. 17639-44, Oct. 2012.

[137] P. Joling et al., "Binding of human immunodeficiency virus type-1 to follicular dendritic cells in vitro is complement dependent.," J. Immunol., vol. 150, no. 3 , pp. 1065-73, Feb. 1993.

[138] R. Ellegård et al., "Complement opsonization of HIV-1 results in decreased antiviral and inflammatory responses in immature dendritic cells via $\mathrm{CR}_{3} ., " J$. Immunol., vol. 193, no. 9, pp. 4590-601, Nov. 2014.

[139] M. H. Faridi, M. M. Altintas, C. Gomez, J. C. Duque, R. I. Vazquez-Padron, and V. Gupta, "Small molecule agonists of integrin CD11b/CD18 do not induce global conformational changes and are significantly better than activating antibodies in reducing vascular injury," Biochim. Biophys. Acta - Gen. Subj., vol. 1830, no. 6, pp. 3696-3710, Jun. 2013.

[140] R. A. Botting et al., "Langerhans cells and sexual transmission of HIV and HSV," Rev. Med. Virol., vol. 27, no. 2, p. e1923, Mar. 2017.

[141] A. Bender, M. Sapp, G. Schuler, R. M. Steinman, and N. Bhardwaj, "Improved methods for the generation of dendritic cells from nonproliferating progenitors in human blood," J. Immunol. Methods, vol. 196, no. 2, pp. 121-135, Sep. 1996.

[142] E. Elkord, P. E. Williams, H. Kynaston, and A. W. Rowbottom, "Human monocyte isolation methods influence cytokine production from in vitro generated dendritic cells.," Immunology, vol. 114, no. 2, pp. 204-12, Feb. 2005.

[143] R. Ellegård et al., "Complement-Opsonized HIV-1 Alters Cross Talk Between Dendritic Cells and Natural Killer (NK) Cells to Inhibit NK Killing and to Upregulate PD-1, CXCR3, and CCR4 on T Cells," Front. Immunol., vol. 9, p. 899, Apr. 2018.

[144] R. Ellegard et al., "Impaired NK cell activation and chemotaxis toward dendritic cells exposed to complement-opsonized HIV-1," J. Immunol., vol. 195, no. 4, 2015 .

[145] P. Carrega and G. Ferlazzo, "Natural killer cell distribution and trafficking in human tissues," Front. Immunol., vol. 3, p. 347, 2012.

[146] A. Cerwenka and L. L. Lanier, "Natural killer cells, viruses and cancer," Nat. Rev. 
Immunol., vol. 1, no. 1, pp. 41-49, Oct. 2001.

[147] D. S. Kaufman, R. A. Schoon, and P. J. Leibson, "MHC class I expression on tumor targets inhibits natural killer cell-mediated cytotoxicity without interfering with target recognition.," J. Immunol., vol. 150, no. 4, pp. 1429-36, Feb. 1993 .

[148] I. E. Dumitriu, W. Mohr, W. Kolowos, P. Kern, J. R. Kalden, and M. Herrmann, "5,6-Carboxyfluorescein Diacetate Succinimidyl Ester- Labeled Apoptotic and Necrotic as Well as Detergent- Treated Cells Can Be Traced in Composite Cell Samples," 2001.

[149] B. P. Jama and G. P. Morris, "Generation of human alloantigen-specific T cells from peripheral blood.,” J. Vis. Exp., no. 93, p. e52257, Nov. 2014.

[150] J.-J. Schnorr, S. Xanthakos, P. Keikavoussi, E. Kampgen, V. ter Meulen, and S. Schneider-Schaulies, "Induction of maturation of human blood dendritic cell precursors by measles virus is associated with immunosuppression," Proc. Natl. Acad. Sci., vol. 94, no. 10, pp. 5326-5331, May 1997.

[151] S. I. Gringhuis, M. van der Vlist, L. M. van den Berg, J. den Dunnen, M. Litjens, and T. B. H. Geijtenbeek, "HIV-1 exploits innate signaling by TLR8 and DCSIGN for productive infection of dendritic cells.," Nat. Immunol., vol. 11, no. 5, pp. 419-26, May 2010.

[152] J. Decalf et al., "Sensing of HIV-1 Entry Triggers a Type I Interferon Response in Human Primary Macrophages," J. Virol., vol. 91, no. 15, pp. eo0147-17, Aug. 2017.

[153] A. N. Harman et al., "HIV infection of dendritic cells subverts the IFN induction pathway via IRF-1 and inhibits type 1 IFN production.," Blood, vol. 118, no. 2, pp. 298-308, Jul. 2011.

[154] K. Soukup et al., "The MAPK-Activated Kinase MK2 Attenuates Dendritic CellMediated Th1 Differentiation and Autoimmune Encephalomyelitis.," $J$. Immunol., vol. 195, no. 2, pp. 541-52, Jul. 2015.

[155] W. Hu et al., "Differential outcome of TRIF-mediated signaling in TLR4 and TLR3 induced DC maturation.," Proc. Natl. Acad. Sci. U. S. A., vol. 112, no. 45, pp. 13994-9, Nov. 2015.

[156] S. H. Jackson, C.-R. Yu, R. M. Mahdi, S. Ebong, and C. E. Egwuagu, "Dendritic cell maturation requires STAT1 and is under feedback regulation by suppressors of cytokine signaling.," J. Immunol., vol. 172, no. 4, pp. 2307-15, Feb. 2004.

[157] M. C. Morris, E. A. Gilliam, and L. Li, "Innate immune programing by endotoxin and its pathological consequences.," Front. Immunol., vol. 5, p. 680, Jan. 2014.

[158] M. Iwanaszko and M. Kimmel, "NF- $\mathrm{KB}$ and IRF pathways: cross-regulation on target genes promoter level," BMC Genomics, vol. 16, no. 1, p. 307, Dec. 2015.

[159] K. Honda, A. Takaoka, and T. Taniguchi, "Review Type I Inteferon Gene Induction by the Interferon Regulatory Factor Family of Transcription Factors," Immunity, vol. 25, pp. 349-360, 2006.

[160] B. Piqueras, J. Connolly, H. Freitas, A. K. Palucka, and J. Banchereau, "Upon viral exposure, myeloid and plasmacytoid dendritic cells produce 3 waves of distinct chemokines to recruit immune effectors," Blood, vol. 107, no. 7, pp. 2613-2618, Apr. 2006.

[161] Z. Bajtay, C. Speth, A. Erdei, and M. P. Dierich, "Cutting edge: productive HIV-1 infection of dendritic cells via complement receptor type 3 (CR3, CD11b/CD18).," J. Immunol., vol. 173, no. 8, pp. 4775-8, Oct. 2004.

[162] G. Hajishengallis and J. D. Lambris, "Microbial manipulation of receptor crosstalk in innate immunity," Nat. Rev. Immunol., vol. 11, no. 3, pp. 187-200, Mar. 2011.

[163] X. Zhang et al., "Regulation of Toll-like receptor-mediated inflammatory response by complement in vivo.," Blood, vol. 110, no. 1, pp. 228-36, Jul. 2007.

[164] J. C. Kagan and R. Medzhitov, "Phosphoinositide-Mediated Adaptor Recruitment Controls Toll-like Receptor Signaling," Cell, vol. 125, no. 5, pp. 943955, Jun. 2006.

[165] C. Han, J. Jin, S. Xu, H. Liu, N. Li, and X. Cao, "Integrin CD11b negatively regulates TLR-triggered inflammatory responses by activating Syk and promoting degradation of MyD88 and TRIF via Cbl-b.," Nat. Immunol., vol. 11, no. 8, pp. 734-42, Aug. 2010. 
[166] J. H. Reed et al., "Complement Receptor 3 Influences Toll-like Receptor 7/8Dependent Inflammation: IMPLICATIONS FOR AUTOIMMUNE DISEASES CHARACTERIZED BY ANTIBODY REACTIVITY TO

RIBONUCLEOPROTEINS," J Biol Chem, vol. 288, no. 13, pp. 9077-9083, 2013.

[167] M. Wang et al., "Fimbrial proteins of porphyromonas gingivalis mediate in vivo virulence and exploit TLR2 and complement receptor 3 to persist in macrophages.," J. Immunol., vol. 179, no. 4, pp. 2349-58, Aug. 2007.

[168] O. V Vieira, R. J. Botelho, and S. Grinstein, "Phagosome maturation: aging gracefully.,” Biochem. J., vol. 366, no. Pt 3, pp. 689-704, Sep. 2002.

[169] V. Tjomsland et al., "Complement opsonization of HIV-1 results in a different intracellular processing pattern and enhanced MHC class I presentation by dendritic cells," Eur. J. Immunol., vol. 43, no. 6, 2013.

[170] D. Mevorach, J. O. Mascarenhas, D. Gershov, and K. B. Elkon, "Complementdependent clearance of apoptotic cells by human macrophages.," J. Exp. Med., vol. 188, no. 12, pp. 2313-20, Dec. 1998.

[171] G. Amarilyo et al., "iC3b-opsonized apoptotic cells mediate a distinct antiinflammatory response and transcriptional NF-kappaB-dependent blockade.," Eur. J. Immunol., vol. 40, no. 3, pp. 699-709, Mar. 2010.

[172] S. Dai, M. V. S. Rajaram, H. M. Curry, R. Leander, and L. S. Schlesinger, "Fine tuning inflammation at the front door: macrophage complement receptor 3 mediates phagocytosis and immune suppression for Francisella tularensis.," PLoS Pathog., vol. 9, no. 1, p. e1003114, Jan. 2013.

[173] A. L. Roberts, B. G. F€ Urnrohr, T. J. Vyse, and B. Rhodes, "The complement receptor $3(\mathrm{CD} 11 \mathrm{~b} / \mathrm{CD} 18)$ agonist Leukadherin-1 suppresses human innate inflammatory signalling."

[174] V. Tjomsland, R. Ellegård, K. Che, J. Hinkula, J. D. Lifson, and M. Larsson, "Complement Opsonization of HIV-1 Enhances the Uptake by Dendritic Cells and Involves the Endocytic Lectin and Integrin Receptor Families.," PLoS One, vol. 6, no. 8, p. e23542, Jan. 2011.

[175] C. Krapp, K. Jønsson, and M. R. Jakobsen, "STING dependent sensing - Does HIV actually care?," Cytokine Growth Factor Rev., vol. 40, pp. 68-76, Apr. 2018.

[176] T. Booiman and N. A. Kootstra, "Polymorphism in IFI16 affects CD4(+) T-cell counts in HIV-1 infection.," Int. J. Immunogenet., vol. 41, no. 6, pp. 518-20, Dec. 2014.

[177] A. Sivro, R.-C. Su, F. A. Plummer, and T. B. Ball, "HIV and Interferon Regulatory Factor 1: A Story of Manipulation and Control," AIDS Res. Hum. Retroviruses, vol. 29, no. 11, pp. 1428-1433, Nov. 2013.

[178] S. Demaria, "TREX1 as a gate-keeper of cGAS/STING-mediated activation of interferon type I in cancer cells treated with DNA-damaging agents," Ann. Oncol., vol. 29, no. suppl_3, Mar. 2018.

[179] C. Oh et al., "A central role for PI3K-AKT signaling pathway in linking SAMHD1deficiency to the type I interferon signature," Sci. Rep., vol. 8, no. 1, p. 84, Dec. 2018.

[180] F. Coquel et al., "SAMHD1 acts at stalled replication forks to prevent interferon induction," Nature, vol. 557, no. 7703, pp. 57-61, May 2018.

[181] H. Ishikawa and G. N. Barber, "The STING pathway and regulation of innate immune signaling in response to DNA pathogens.," Cell. Mol. Life Sci., vol. 68, no. 7, pp. 1157-65, Apr. 2011.

[182] C. Tomescu et al., "Increased plasmacytoid dendritic cell maturation and natural killer cell activation in HIV-1 exposed, uninfected intravenous drug users," AIDS, vol. 24, no. 14, pp. 2151-216o, Sep. 2010.

[183] H. Saïdi, M.-T. Melki, and M.-L. Gougeon, "HMGB1-dependent triggering of HIV-1 replication and persistence in dendritic cells as a consequence of NK-DC cross-talk.," PLoS One, vol. 3, no. 10, p. e3601, Jan. 2008.

[184] G. Ferlazzo, "Human Dendritic Cells Activate Resting Natural Killer (NK) Cells and Are Recognized via the NKp3o Receptor by Activated NK Cells," J. Exp. Med., vol. 195, no. 3, pp. 343-351, Feb. 2002.

[185] T. Walzer, M. Dalod, S. H. Robbins, L. Zitvogel, and E. Vivier, "Natural-killer cells and dendritic cells: 'l'union fait la force,"' Blood, vol. 106, no. 7, pp. 2252-8, 
Oct. 2005 .

[186] E. M. Shankar, K. F. Che, D. Messmer, J. D. Lifson, and M. Larsson, "Expression of a broad array of negative costimulatory molecules and Blimp-1 in T cells following priming by HIV-1 pulsed dendritic cells.," Mol. Med., vol. 17, no. 3-4, pp. 229-40.

[187] F. Sallusto, J. Geginat, and A. Lanzavecchia, "Central Memory and Effector Memory T C ll Subsets : Function, Generation, and Maintenance," Annu. Rev. Immunol., vol. 22, no. 1, pp. 745-763, Apr. 2004.

[188] S. M. Gonzalez, N. A. Taborda, and M. T. Rugeles, "Role of Different Subpopulations of CD8+ T Cells during HIV Exposure and Infection," Front. Immunol., vol. 8, Aug. 2017.

[189] N. Chomont et al., "HIV reservoir size and persistence are driven by T cell survival and homeostatic proliferation.," Nat. Med., vol. 15, no. 8, pp. 893-900, Aug. 2009.

[190] V. Velu, R. D. Shetty, M. Larsson, and E. M. Shankar, "Role of PD-1 co-inhibitory pathway in HIV infection and potential therapeutic options.," Retrovirology, vol. 12, no. 1, p. 14, Feb. 2015.

[191] A. L. Meditz et al., "HLA-DR+ CD38+ CD4+ T lymphocytes have elevated CCR5 expression and produce the majority of R5-tropic HIV-1 RNA in vivo.," J. Virol., vol. 85, no. 19, pp. 10189-200, Oct. 2011.

[192] A.-B. Löfroos, M. Kadivar, S. Resic Lindehammer, and J. Marsal, "Colorectal cancer-infiltrating $\mathrm{T}$ lymphocytes display a distinct chemokine receptor expression profile.," Eur. J. Med. Res., vol. 22, no. 1, p. 40, Oct. 2017.

[193] A. Iellem et al., "Unique chemotactic response profile and specific expression of chemokine receptors CCR4 and CCR 8 by $\mathrm{CD} 4(+) \mathrm{CD} 25(+)$ regulatory T cells.," $J$. Exp. Med., vol. 194, no. 6, pp. 847-53, Sep. 2001. 


\section{Papers}

The papers associated with this thesis have been removed for copyright reasons. For more details about these see:

http://urn.kb.se/resolve?urn=urn:nbn:se:liu:diva-151665 